Utah State University

DigitalCommons@USU

\title{
Connections Between Hydrothermal System Geochemistry and Microbiology: Traversing Tectonic Boundaries in the South-Central Peruvian Andes
}

Heather Upin

Utah State University

Follow this and additional works at: https://digitalcommons.usu.edu/etd

Part of the Geochemistry Commons, Geology Commons, and the Microbiology Commons

\section{Recommended Citation}

Upin, Heather, "Connections Between Hydrothermal System Geochemistry and Microbiology: Traversing Tectonic Boundaries in the South-Central Peruvian Andes" (2020). All Graduate Theses and Dissertations. 7887.

https://digitalcommons.usu.edu/etd/7887

This Thesis is brought to you for free and open access by the Graduate Studies at DigitalCommons@USU. It has been accepted for inclusion in All Graduate Theses and Dissertations by an authorized administrator of DigitalCommons@USU. For more information, please contact digitalcommons@usu.edu.

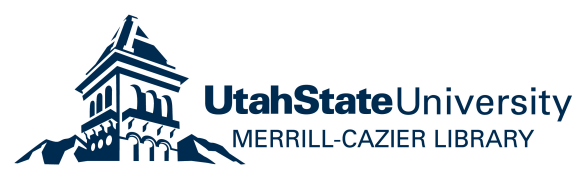


CONNECTIONS BETWEEN HYDROTHERMAL SYSTEM GEOCHEMISTRY AND

MICROBIOLOGY: TRAVERSING TECTONIC BOUNDARIES IN THE SOUTH-

CENTRAL PERUVIAN ANDES

by

Heather Upin

A thesis submitted in partial fulfillment

of the requirements for the degree

of

MASTER OF SCIENCE

in

Geosciences

Approved:

Dennis Newell, Ph.D.

Major Professor

Alexis Ault, Ph.D.

Committee Member

Eric Boyd, Ph.D.

Committee Member

Janis L. Boettinger, Ph.D.

Acting Vice Provost of Graduate Studies

UTAH STATE UNIVERSITY

Logan, Utah 
Copyright (C) Upin 2020

All Rights Reserved 


\begin{abstract}
Connections between hydrothermal systems

geochemistry and microbiology: traversing tectonic

boundaries in the south-central Peruvian Andes
\end{abstract}

by

Heather Upin, Master of Science

Utah State University, 2020

\title{
Major Professor: Dr. Dennis Newell
}

Department: Geosciences

Hot springs in continental arcs exhibit varied geochemistry, reflecting tectonomagmatic influences, fluid-rock interactions, and inputs from deeply-derived volatiles, that provide compositionally diverse niches for microbial life. Here we report new water, gas, and molecular microbiology data from 14 thermal springs along a transect from the amagmatic flat-slab region to the active magmatic arc in southern Peru. The springs examined are slightly acidic ( $\mathrm{pH} 5.3-6.8)$, exhibit a wide range in surface temperature (17$81^{\circ} \mathrm{C}$ ), and have variable subsurface reservoir temperature estimates (RTEs) of $40-240{ }^{\circ} \mathrm{C}$ based on geothermometry. Springs contain a variety of redox sensitive species including $\mathrm{Fe}^{2+}(0.54-28 \mathrm{ppm})$ and As $(0.01-23 \mathrm{ppm})$, and dissolved $\mathrm{O}_{2}(0.002-0.253 \mathrm{mM})$ and $\mathrm{H}_{2}$ $(0.075-1.612 \mu \mathrm{M})$. There are geochemical and microbial differences between springs in the flat-slab (flat-slab springs, FSS) and back-arc (back-arc springs, BAS) regions. A principle component analysis of physiochemical parameters indicates four distinct 
geochemical groups of springs. There are two FSS groups that are characterized by major ions and atmospheric gas signatures, and two BAS groups characterized by volatile signatures indicative of volcanic influence. Analysis of Similarities (ANOSIM) identified statistically significant relationships between spring geochemistry, microbial community composition, and geologic setting. FSS are chemically heterogenous, have modest surface temperatures $\left(20-45^{\circ} \mathrm{C}\right)$ and RTEs $\left(40-193{ }^{\circ} \mathrm{C}\right)$, and are dominated by members of the metabolically diverse phylum Proteobacteria $(42.2 \%$ of sequences). BAS are more geochemically homogenous, exhibit high concentrations of metals and dissolved gas, have generally elevated surface temperatures $\left(43-81^{\circ} \mathrm{C}\right.$, with one spring $\left.17^{\circ} \mathrm{C}\right)$ and RTEs $(117-$ $240{ }^{\circ} \mathrm{C}$ ), and host a diverse group of putatively thermophilic microorganisms including Deinococcus-Thermus (18.4\%), Thaumarchaeota (5.6\%), and Crenarchaeota (4.4\%) phyla. Flat-slab spring characteristics and microbial communities are impacted by near-surface water-rock re-equilibration and groundwater mixing; whereas, higher heat flow and increased contribution of volatiles shows influence from young magmatism in backarc springs. Our data suggest that transitions in tectonic setting influence the interplay of geochemistry and the resulting microbiology by altering the availability of nutrients through flow path processes such as circulation depth and extent of water-rock interaction. 


\title{
PUBLIC ABSTRACT
}

\author{
Connections between hydrothermal systems \\ geochemistry and microbiology: traversing tectonic \\ boundaries in the south-central Peruvian Andes \\ Heather Upin
}

Geochemistry and microbiology are inherently tied in the natural world. The study of geomicrobiology has historically taken place in extreme systems, like hot springs of Yellowstone National Park and deep-sea hydrothermal vents, because the organisms that exist there have deep lineages on the tree of life and provide insight into early life on Earth. These microbes use chemical energy from nutrients available in their environment rather than relying on photosynthesis, energy obtained from the sun, to support their metabolism. The goal of this study is to improve our understanding of geological controls (for example the tectonic setting) on hot spring geomicrobiology. Fourteen thermal springs were sampled for aqueous and gas geochemistry and molecular microbiology along a transect from the Peruvian flat-slab subduction segment southward to the back-arc setting with steep-dip subduction in the Altiplano. The flat-slab region currently lacks active magmatic activity in contrast to southern Peru that is characterized by active arc volcanoes and behind the arc volcanism. Flat-slab springs (FSS) are cooler, more geochemically varied, and are supported by cooler subsurface reservoir temperatures compared to back-arc springs (BAS). Conversely, BAS have higher temperatures, exclusively $\mathrm{Na}-\mathrm{Cl}$ rich waters, and are supported by hot subsurface temperatures. Statistical analyses were employed to meaningfully interpret and link the geochemistry and microbial community datasets. 
Significant relationships between spring geochemistry, spring temperature, microbial community composition, and geologic setting show that the FSS and BAS contain different phyla based on geologically influenced characteristics (i.e. temperature, chemistry). Our findings show that geological processes deep in the subsurface impart a primary control on surface geomicrobiological diversity. 


\section{ACKNOWLEDGEMENTS}

There have been many people who have helped me throughout my thesis process. First and foremost I would like to thank my friends and family for constantly being there for me and encouraging me to conquer my goals.

Many folks have helped me in the field, lab, and office. First, thank you to Alberto Cafferata, our Peruvian guide, who drove us almost 4,000 km around south-central Peru to gather hot spring samples. Thank you to the Utah State University Water Research Lab for running our water samples and to the University of New Mexico Fluid and Volatiles Lab for obtaining our gas chemistry. Thank you to the Boyd Lab, specifically Dan Colman and Melody Lindsay, for welcoming me and helping me process my microbial DNA samples. I would like to thank Bonnie Waring and Susan Durham at Utah State University for their help decoding the mystery of OTUs and R statistical analyses. A huge thank you to Ellen Imler and Hollie Richards in the main office of the Geosciences Department, for not only their help with paperwork but more importantly their continual support and encouragement. Thank you to Mikaela Pulsipher and Julia Greider for reading my entire thesis for spelling and grammatical errors. To my committee, Alexis Ault and Eric Boyd, thank you for your thoughts and edits that made my thesis stronger. Eric, thank you for letting me work in your lab and sharing your knowledge of microbes with me.

Finally, the biggest thank you to my advisor Dennis Newell. You have been an outstanding mentor and I appreciate all our conversations, academic or otherwise. Thank you so much for suggesting microbes, I deeply enjoyed learning about a new topic of science that I would never have considered otherwise. Thank you for your faith in me to take on this new and exciting direction to your Peru work. 


\section{CONTENTS}

Page

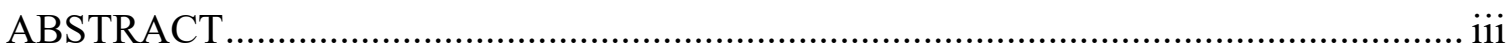

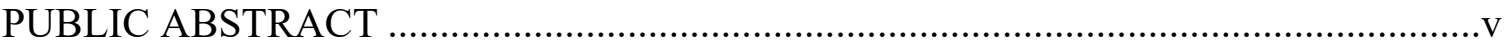

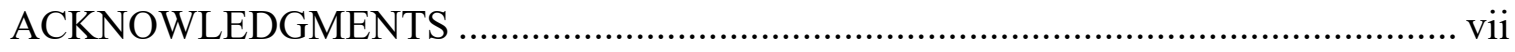

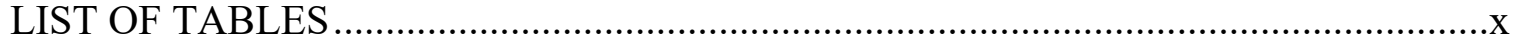

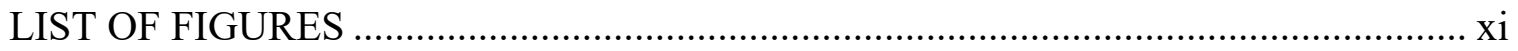

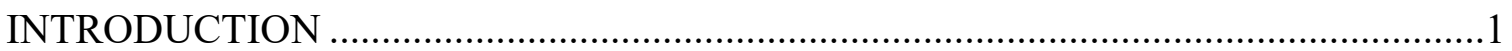

GEOLOGIC SETTING AND HISTORY .............................................................4

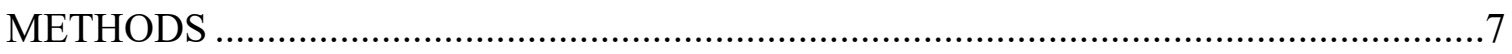

Field methods and sampling .....................................................................

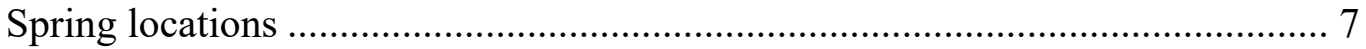

Aqueous and gas samples and field measurements ...................................... 8

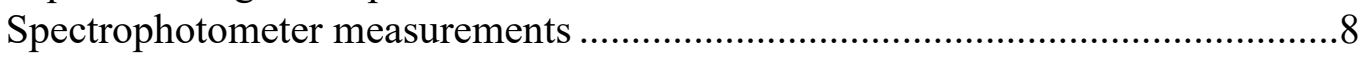

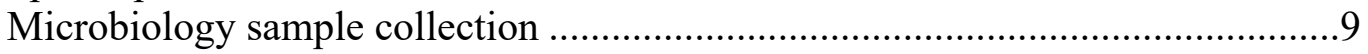

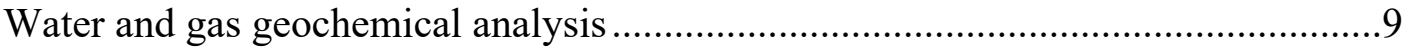

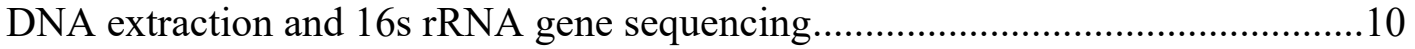

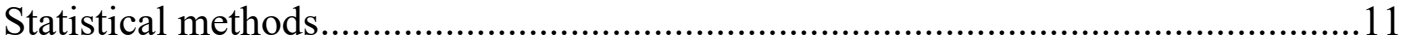

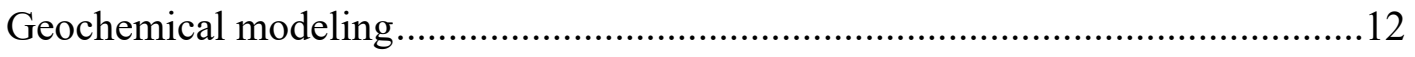

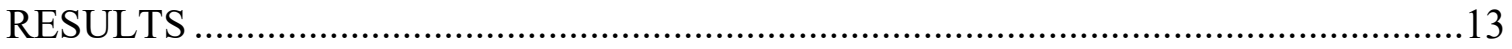

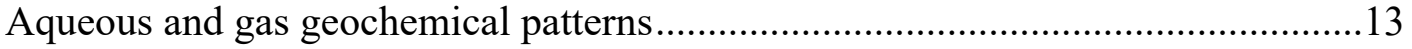

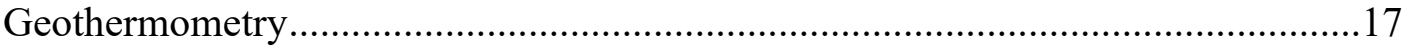

Molecular microbiology of spring systems ................................................. 18

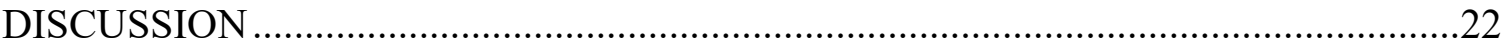

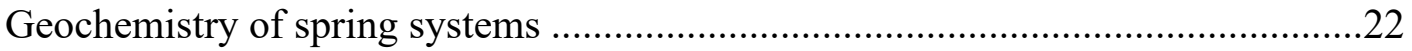

Microbial community ecology and connections to tectonic setting .......................28

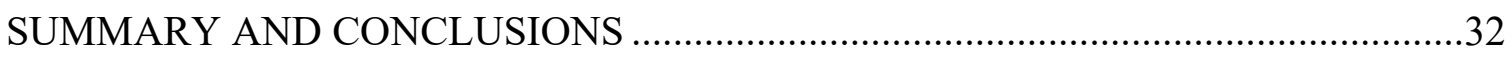

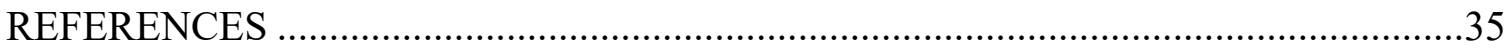

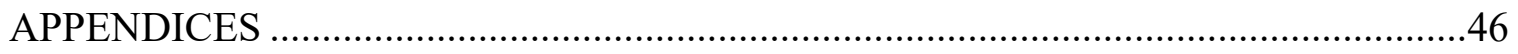

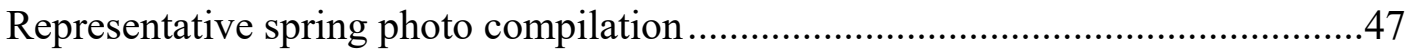


Aqueous and gas geochemistry and geothermometry data tables.......................49

Taxonomic information for $\geq 1 \%$ abundant OTUs ................................................52

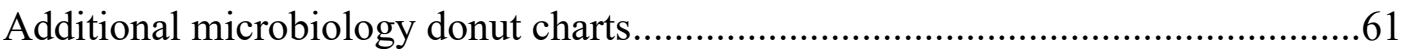

Additional NMDS ordinations and statistical summary ..................................64

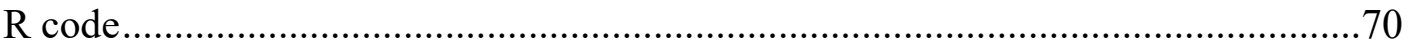




\section{LIST OF TABLES}

Table Page

1. Spring identification, location, and field parameters ..................................... 14

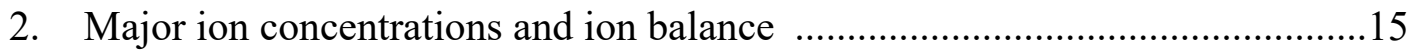

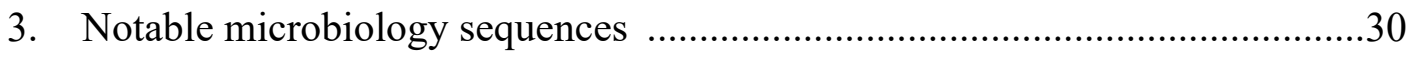

A1. Trace element and gas chemistry ….........................................................

A2. Geothermometry temperature estimates ...................................................51

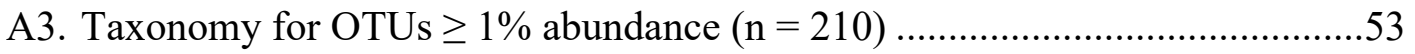

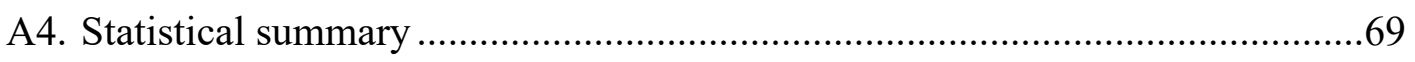




\section{LIST OF FIGURES}

Figure Page

1. Spring location and tectonic setting map ...................................................

2. Major element Piper diagram and principle component analysis ...................15

3. Microbial community class-level taxonomic data ....................................20

4. Non-metric multidimensional scaling (NMDS) ordination ...........................22

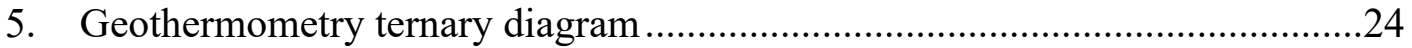

6. Tectonic setting cross sections with microbiology donut charts.....................26

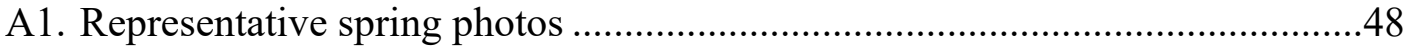

A2. Microbial community taxonomic donut charts (3 levels) ............................62

A3. Novel verses characterized sequences donut charts..................................63

A4. Subsampled dataset NMDS ordinations ....................................................65 


\section{INTRODUCTION}

Hot springs are geochemically heterogeneous environments that create ecological niches capable of supporting diverse populations of microorganisms (e.g., Macur et al., 2004; Inskeep et al., 2005; Huang et al., 2011; Hurwitz and Lowenstern, 2014; Wang et al., 2014; Colman et al., 2016). The biodiversity that inhabits these environments includes those microorganisms that use light for energy and those that are dependent on chemical energy. Photosynthetic processes convert light into chemical energy and have a functional upper limit of $\sim 73{ }^{\circ} \mathrm{C}$ (Brock, 1967; Boyd et al., 2012), limiting their existence to lower temperature hot spring systems. Chemosynthetic-dependent organisms can live above or below this temperature and are thus less limited by the physiochemical properties of the fluid environment. Non-photosynthetic microorganisms exploit disequilibrium in electron donor and acceptor pairs to generate energy for macromolecular biosynthesis and growth (Shock et al., 2010; Colman et al., 2016; Jelen et al., 2016; Merino et al., 2019). At hot springs, reduced subsurface thermal fluids mix with more oxidized near-surface groundwater to generate redox disequilibrium capable of providing a continual source of potential energy to support microbial life.

Thermal spring geochemistry is controlled by the depth of fluid circulation, the types of rocks encountered along fluid flow paths, water-rock interactions along these pathways, and the degree of mixing with shallow meteoric groundwater (e.g., Fournier, 1989; Arnold et al., 2017). These factors are closely tied to the overall tectono-magmatic setting, and spring chemical and isotopic composition (e.g., He, C, O, S) can inform the relative contribution from magmatic, crustal, and meteoric sources (Hilton, 1996; van Soest et al., 1998; de Hoog et al., 2001; Hilton et al., 2002; Zimmer et al., 2004; Newell et al., 
2008; Sano et al., 2009; Scott et al., 2020). Given the linkages between spring chemistry and microbiology it is likely that the types of microorganisms inhabiting hot springs may also be influenced by tectonic setting.

The link between geomicrobiology and host environment has been investigated at many continental hydrothermal systems (Shock et al., 2010; Colman et al., 2014; Colman et al., 2016), marine deep sea vents (Amend et al., 2011; Reveillaud et al., 2016), in deep wells and pore fracture fluids (Kieft et al., 2005; Moser et al., 2005; Rempfert et al., 2017), and at convergent margins associated with volcanic arcs (Burgess et al., 2012; Ward et al., 2017; Barry et al., 2019). Recent work at the magmatically active Costa Rican continental arc suggests that microbial respiration plays an important role in volatile cycling (Barry et al., 2019; Fullerton et al., 2019). Collectively, existing geomicrobiological research in tectonically active systems supports relationships between hot spring environment and microbiology, and hints at a connection to the tectonic setting that can be quantified. Continental arc settings exhibit distinct variations and transitions in tectonic style (e.g., subduction angle, magmatic gaps) and provide an opportunity to make direct comparisons between tectonic setting, geochemistry, and geomicrobiology.

Peru hosts an excellent example of a shift in subduction style (i.e., tectonic setting) along a continental arc, where a gap in magmatism associated with flat-slab subduction transitions southward to steeper subduction and an active magmatic arc (Fig.1). Here, we explore the interplay between tectonic setting in the Peruvian Andes, its influence on the geochemistry of hot spring emanations, and how these factors shape the composition of hot spring microbial communities. We investigate thermal springs in both the amagmatic flat-slab subduction and magmatically-active back-arc settings via a $1000 \mathrm{~km}$, broadly arc- 
parallel sampling transect (Fig. 1). We report new major and trace element chemistry, gas composition, and molecular microbiological results from 14 thermal spring systems to characterize relationships between tectonic setting, spring geochemistry, and microbial diversity. We suggest that differences in subduction style and magmatic activity exert strong controls on the diversity and putative function of microorganisms observed at thermal springs. In particular, we hypothesize that the composition of microbial communities reflects their environment and the availability of nutrients provided by geofluid-rock interaction along flow paths, which is ultimately influenced by the underlying tectonic setting.

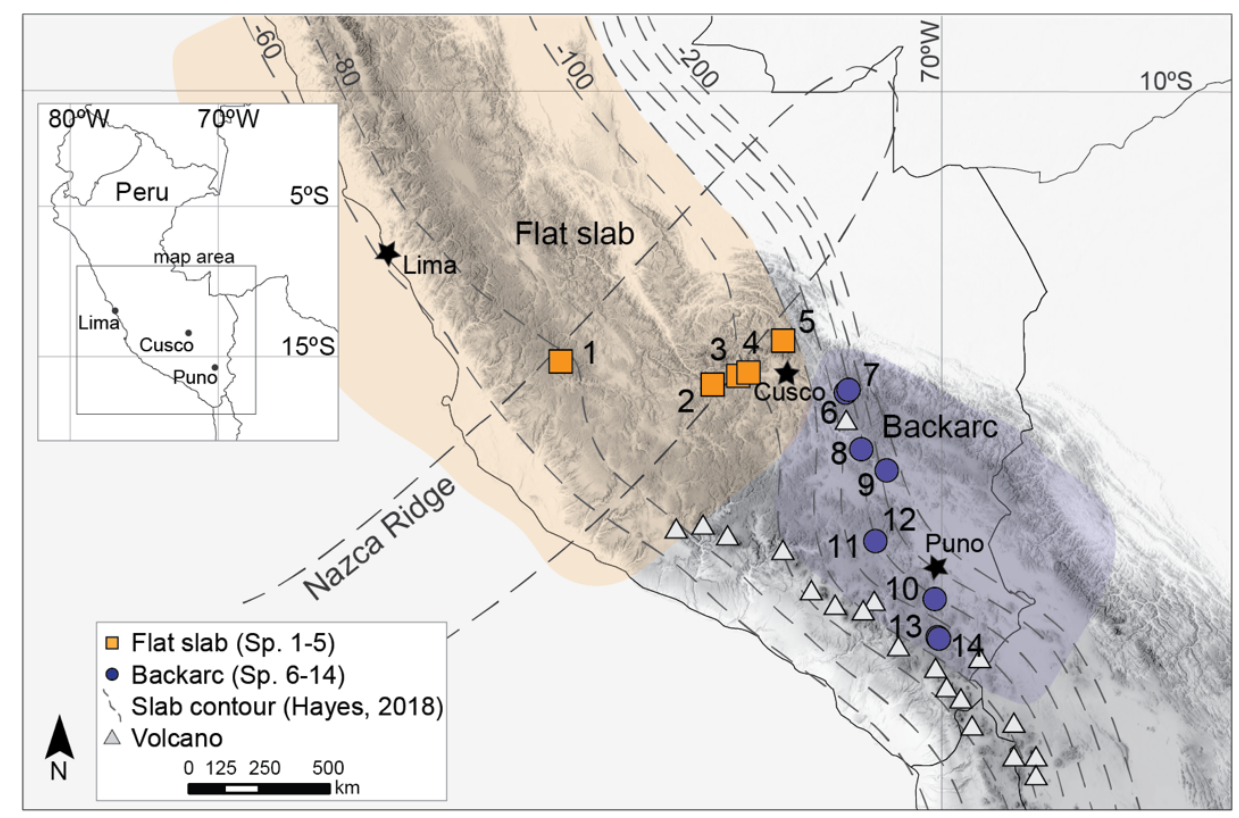

Figure 1. Thermal springs (1-14) investigated along a NW-SE transect from the Peruvian flat-slab subduction segment into the backarc of the active subduction segment. Springs 15 are within the flat-slab region, and springs $6-14$ are located in the backarc. The subducting Nazca slab contours (km) are from the Slab2 model (Hayes, 2018) and offer a schematic of slab depth and geometry. 


\section{GEOLOGIC SETTING AND HISTORY}

Flat-slab subduction $\left(\sim<10^{\circ}\right.$ slab angle $)$ is observed at $\sim 10 \%$ of continental arcs and places the down-going oceanic plate into contact with the overriding lithosphere (e.g., James, 1978; Gutscher et al., 2000). A flat slab geometry eliminates the asthenospheric wedge and ceases the generation of melts, resulting in prominent gaps in magmatism along continental arcs. Today, most of the western South American margin is characterized by normal $\left(\sim 30^{\circ}\right)$ subduction and active arc volcanism (Horton, 2018). These volcanically active sections of the Andean arc are separated by three prominent magmatic gaps associated with flat-slab subduction (Gutscher et al., 2000; Ramos and Folguera, 2009). The longest of these flat-slab segments (both in the Andes and worldwide) underlies most of Peru. This flat slab is coincident with the subducting Nazca ridge; however, the triggers and controls on flat-slab subduction are complicated and debated (e.g., Abbot et al., 1994; Ramos and Folguera, 2009; Antonijevic et al., 2015; Manea et al., 2017). South of the Nazca ridge, the flat slab steepens to normal subduction and an active arc (Fig. 1). Here, the back-arc region is geographically part of the Altiplano Plateau, the second highest continental plateau in the world and the highest at a non-collisional convergent margin (Lamb and Hoke, 1997; Allmendinger et al., 1997).

Prior to $\sim 11 \mathrm{Ma}$, most of the present-day flat-slab segment was an active arc with normal-dip subduction as evidenced by widespread Cretaceous-Neogene plutons and volcanic rocks (Megard, 1984; Cobbing, 1999; Gutscher et al., 2000; Ramos and Folguera, 2009). A magmatic lull at the end of the Miocene signals the establishment of the Peruvian flat slab, concurrent with the Nazca Ridge subducting beneath the South American plate (Ramos and Folguera, 2009). The flat slab has been migrating southeastward due to the 
oblique subduction of the Nazca plate, and presently the widest part of the flat-slab region is located above the Nazca Ridge (Gutscher et al., 2000; Hampel, 2002; Scire et al., 2016). Southeast of this area, the Altiplano Plateau preserves a prior geological record of the flatto-steep subduction cycle (Lamb and Hoke, 1997; Ramos and Folguera, 2009; Mamani et al., 2010). Slab shallowing, evidenced by an eastward migration of volcanism, occurred between $\sim 45$ and $30 \mathrm{Ma}$, ultimately leading to the termination of arc magmatism (Mamani et al., 2010). A flat slab existed from $\sim 30$ to $25 \mathrm{Ma}$, which correlates with a lack of igneous rocks of this age (Ramos and Folguera, 2009). Widespread volcanism returned to this area $\sim 26$ to 22 Ma coincident with slab rollback and re-steepening (Sandeman et al., 1995; Allmendinger et al., 1997; Hoke and Lamb, 2007; Mamani et al., 2010; Horton et al., 2014).

The south-central Peruvian Andes are characterized geologically by three prominent morphostructural features: the Western Cordillera, the Altiplano Plateau, and the Eastern Cordillera. In the study area, the Western Cordillera defines the active arc, the Altiplano Plateau defines the high-elevation back-arc region, and the Eastern Cordillera is characterized by the thin-skinned Marañon fold and thrust belt (Megard, 1984; Lamb and Hoke, 1997; Scherrenberg et al., 2016). Generally, the Western Cordillera is composed of sedimentary strata with a continental history and plutonic and volcanic igneous rocks, including several granitoid batholiths along the coast (McKee and Noble, 1982; Cobbing, 1999). The Altiplano Plateau is characterized by Mesozoic marine and continental sedimentary rocks with some Cenozoic volcanoclastic units, and the Eastern Cordillera is characterized by upper Paleozoic volcano-sedimentary and plutonic rocks that post-date deformed lower Paleozoic plutonic and shallow marine sedimentary series (Suárez et al., 1983; Cabrera et al., 1991). Recent back-arc magmatism in the Altiplano is exemplified by 
Cretaceous-Tertiary volcanic rocks. The youngest magmatic activity in the backarc and northern Altiplano is represented by a relatively small volume of Pliocene-Quaternary ultra-potassic intermediate intrusive and volcanic rocks, that host mantle and crustal xenoliths (Chapman et al., 2015). These recent magmatic rocks include 11-6 ka flows from the Quimsachata volcano southwest of Cusco (Global Volcanism Program, 2013). This activity is relevant to this study because young magmatism injects volatiles into the lithosphere, affecting the geochemical composition of hot springs in the surrounding region (e.g., Hilton et al., 1996).

The structural geology of south-central Peru is dominated by the thin-skinned deformation of the Marañon fold and thrust belt (Megard, 1984; Scherrenberg et al., 2016) near Cusco. Specifically, the Cusco region contains many large normal faults and older thrust faults (Megard, 1984; Cabrera et al., 1991); whereas, the Altiplano region is characterized by synsedimentary deformation including tight folding and faulting (Perello et al., 2003). Two generally NW-SE trending fault zones, Limatambo-Ayaviri and Abancay-Yauri faults, dominate the Cusco region and include both reverse and normal faulting (Cabrera et al., 1991; Perello et al., 2003). Regionally, the NW-trending CuscoVilcanota fault system dominates the structure of south-central Peru, separating the Altiplano into two structure blocks (Carlier et al., 2005).

The Peruvian Instituto Geológico Minero y Metalúrgico (INGEMMET) has performed surveys of Peru's hot spring systems to inventory thermal and mineral resources across the country. Two reports encompassing the transition from flat-slab subduction to the active backarc of the Altiplano Plateau provide the preliminary geochemical framework for this study (Steinmüller and Huamaní Huaccán, 1999; Huamaní Huaccán, 2001). In 
addition to INGEMMET reports, geochemical studies on springs in Peru have focused on magmatically active hydrothermal systems (e.g., Pajuelo et al., 2020) and hot springs of the Cordillera Blanca and Cordillera Huayhuash regions (Newell et al., 2015; Scott et al., 2020), providing key data for comparison.

\section{METHODS}

\section{Field methods and sampling}

Spring locations

This study investigates fourteen hot spring systems located along a roughly NWSE transect of the Peruvian Andes (Fig. 1). These springs were selected based on existing geochemical data sets, geographic location, accessibility, and tectonic setting (Steinmüller and Huamaní Huaccán, 1999; Huamaní Huaccán, 2001). The 14 springs are located in the Peruvian provinces of Ayacucho, Apurimac, Cusco, Puno, and Moquegua. Our aim was not to simply target extreme conditions, but rather to capture a range of aqueous and gas chemistries, temperatures, and geological settings. Many spring locations are actually a cluster of individual emanations. In those cases, sampling was based on temperature and specific conductance measurements so that the spring with the least amount of near-surface mixing with dilute and low-temperature groundwater could be targeted (e.g., highest temperature and highest specific conductance). 
Aqueous and gas samples and field measurements

Spring sampling and field measurements were conducted as close to the spring source as possible while maintaining safe distance from hot fluids and unstable ground. Water and gas samples from large high temperature springs were collected using a funnel and tubing attached to a $2.5 \mathrm{~m}$ pole. Specific conductance, $\mathrm{pH}$, and temperature measurements were collected in the field using a portable meter. Water samples for cations were field filtered into $60 \mathrm{~mL}$ wide-mouth Nalgene ${ }^{\circledR}$ HPDE bottles using $0.45 \mu \mathrm{m}$ syringe filters (Thermo Scientific, surfactant-free cellulose acetate). Filtered cation samples were later acidified using $0.5 \mathrm{~mL}$ concentrated trace-metal grade nitric acid. Samples for anions and alkalinity determinations were collected unfiltered into $125 \mathrm{~mL}$ wide-mouth Nalgene ${ }^{\circledR}$ bottles with no head space. In cases where waters were particularly turbid, these samples were also filtered. Gasses from bubbling springs were collected into $12 \mathrm{in.}$ by $3 / 8 \mathrm{in.}$. ID copper tubes via polyethylene tubing and an inverted funnel, and cold sealed using metal clamps following methods adopted from Hilton et al. (2002). The funnel and tubing were flushed with spring water and then gasses before sampling to prevent atmospheric contamination. Samples were kept cool and dark prior to analyses.

\section{Spectrophotometer measurements}

Field spectrophotometer measurements of ferrous iron and sulfide were adapted from the HACH 8146 1,10-Phenanthroline Method and the HACH 8131 USEPA Methylene Blue Method, respectively (HACH 2014; 2015). Using these methods, the dynamic range for ferrous iron $\left(\mathrm{Fe}^{2+}\right)$ is 0.02 to $3.00 \mathrm{mg} / \mathrm{L}$ and 5 to $800 \mu \mathrm{g} / \mathrm{L}$ for sulfide $\left(\mathrm{S}^{2-}\right)$. Samples were collected as close to the source as possible, and readings were taken 
immediately after collection. Samples were initially analyzed undiluted. If concentrations exceeded the maximum range for the method, the samples were diluted as necessary to within the detectable range. Field dilutions were accomplished using bottled water and a $50 \pm 0.5 \mathrm{~mL}$ graduated cylinder.

\section{Microbiology sample collection}

Water (planktonic cells) and sediments (sediment-associated cells) from springs were collected for use in DNA extraction and sequencing. For planktonic cells, 1-3 L of water were passed through $0.2 \mu \mathrm{m}$ Sterivex ${ }^{\circledR}$ filters using a $140 \mathrm{~mL}$ syringe that was flushed with spring water prior to use. After filtration, a volume of air was passed through the Sterivex filter to remove any remaining water from the filter, which was then stored in a sterile Whirl Pak ${ }^{\circledR}$ bag. Microbial mat and sediment samples were collected using a flame sterilized metal spoon and placed into $15 \mathrm{~mL}$ centrifuge tubes. An approximately equal part of sucrose lysis buffer (Mitchell and Takacs-Vesbach, 2008) was added to the sediment and the contents were shaken to coat the entire sample (Colman et al., 2016). All microbiology samples were collected in either duplicate or triplicate and stored at room temperature for 5-15 days until shipment back to Utah State University (USU). Once back in the lab, samples were frozen to $-80^{\circ} \mathrm{C}$.

\section{Water and gas geochemical analyses}

Dissolved gas composition was measured in 10 of the 14 springs using gas chromatography quadrupole mass spectrometry (MS) at the University of New Mexico Fluid and Volatiles Lab. Gas composition was reported as a mole percent and converted to 
dissolved molar concentrations using published Henry's Law constants (Sander, 2005). Major ions and trace elements were measured in 14 springs by inductively coupled plasma MS (ICP-MS) and ion chromatography (IC) respectively at the USU Water Research Lab. Cation and anion samples were volumetrically diluted, as needed, for measurement on the ICP-MS and IC. Alkalinity was measured as total carbonate alkalinity in the USU Geochemistry Lab using colorimetric titration (USGS, 2006).

\section{DNA extraction and 16S rRNA gene sequencing}

Methods for genomic DNA extraction, polymerase chain reaction (PCR) amplification of 16S rRNA genes, sequencing, and informatics were conducted according to the methods outlined in Colman et al. (2016). Briefly, filters were cut open using a sterilized jewelry saw, removed from their housing, and peeled from the filter cartridges using sterilized tweezers. Filters or $\sim 0.35 \mathrm{~g}$ of sediment were placed into FastDNA SPIN kit bead-beating tubes (MP Biomedicals) with sterilized tweezers or spatulas, respectively. DNA was extracted from each using the FastDNA SPIN Kit for Soil using previously described methods in Boyd et al. (2007) and yielded a total of 29 microbiology samples (one filter was split into two tubes due to a large amount of visible biomass). Genomic DNA was quantified using a Qubit fluorescence assay and fluorometer and roughly $200 \mathrm{ng}$ of DNA were subject to PCR using universal primers (515F and 806R) as previously described in Colman et al. (2016). 16S rRNA gene amplicons were sent to the Molecular Research DNA Lab in Shallowater, Texas, for sequencing utilizing the paired end $(2 \times 300$ bp) Illumina MiSeq platform. 
16S rRNA genes were subjected to analysis using the software program Mothur (Schloss et al., 2009) as previously described by Hamilton et al. (2013), Colman et al. (2016), and Lindsay et al. (2018). In short, sequences were filtered, aligned, and trimmed using defined start and end sites based on $85 \%$ inclusion of total sequences. Redundant sequences and sequencing errors were detected and removed. Chimeras were identified and removed using UCHIME (Edgar et al., 2011). Operational taxonomic units (OTUs) were assigned at a sequence similarity of $\geq 97 \%$ using the nearest-neighbor method. The sequence dataset was randomly subsampled to generate 45,226 gene sequences per sample. High abundance OTUs ( $\geq 1 \%$ relative abundance) were subjected to BLASTn analysis to identify the most closely related taxon with a characterized physiology. Adopting this information, a prediction of the metabolism for 16S rRNA gene phylotypes was made for each high abundance OTU.

\section{Statistical methods}

Statistical analyses of geochemical and microbiological data were conducted in RStudio (version 1.1.463). Multivariate analyses, including non-metric multidimensional scaling ordination (NMDS), were accomplished using the vegan package version 2.5-4 (Oksanen, 2015; Oksanen et al., 2019). The NMDS ordinations were made with the metaMDS function and a calculated Bray-Curtis distance matrix with three dimensions for combined sediment and planktonic 16S rRNA gene data. We used the envifit function within metaMDS to assess the correlation between environmental parameters and the community distance matrix. NMDS ordination provides a visualization of community similarity between sites. The function ANOSIM, a program in the vegan package, was used 
to determine the statistical significance of chemical, temperature, and geographic spring groupings. ANOSIM provides a way to test whether different treatments are statistically significant to microbial community similarity, and returns a $P$ value (considered significant if $<0.001 ; 99.9 \%$ confidence) and an R statistic (a metric specific to this program). The $\mathrm{R}$ statistic can vary between -1 and 1 and is based on the dissimilarities between and within groups. If the dissimilarity between groups is high but within groups is low, the R statistic will approach 1, indicating the communities within treatment groups are similar but different from one another. An R statistic of 0 implies random grouping and a negative $\mathrm{R}$ statistic indicates that the dissimilarity within groups is greater than between groups. A principle component analysis (PCA) of standardized temperature, $\mathrm{pH}$, gas, and water composition data was created to address linear relationships between samples and geochemical variables. The PCA was made with the prcomp function in the stats package and graphically displayed with the ggplot 2 package. The plot is considered good if the first two principle components explain the majority of the variance in the dataset $(\geq 50 \%)$.

\section{Geochemical modeling}

Ion balances were calculated with the major ion and trace element chemistry for the 14 springs. The total concentration (in equivalents/L) of cations (c) and anions (a) were used to calculate a percent imbalance using the equation: $([\mathrm{c}]-[\mathrm{a}]) /([\mathrm{c}]+[\mathrm{a}]) * 100$. Geochemists Workbench version 12.0.4 (Bethke, 2008) was used to generate a Piper diagram with the measured major ion chemistry (Piper, 1944), and calculate saturation indices for spring components. 
Reservoir temperature estimates (RTEs) were obtained using empirical and thermodynamically based geothermometers. Multiple thermometers were considered but we focus on the Na-K-Ca, Na-K, and K-Mg cation geothermometers. We do not report silica thermometers because silica measurements were not made for the 14 springs. Calculations are based on original computations and measurements from Fournier and Truesdell (1973) and Giggenbach (1988) and as summarized in Baioumy et al. (2015). The geothermometry spreadsheet calculator from Powell and Cumming (2010) was used to calculate RTEs using the measured water chemistry.

\section{RESULTS}

\section{Aqueous and gas geochemical patterns}

For this study, the spring (Sp.) locations are numbered 1-14 along the sampling transect (Fig. 1; Table 1), where Sp. 1-5 are located above the flat slab (flat-slab springs, FSS) and Sp. 6-14 are located in the backarc (back-arc springs, BAS). Table 1 provides the local names of these springs. Springs range in temperature and $\mathrm{pH}$ from $16.6-80.1{ }^{\circ} \mathrm{C}$ and 5.31-6.84, respectively (Table 1$)$. In general, BAS are hotter $\left(>40^{\circ} \mathrm{C}\right)$ and have slightly more acidic fluids $(5.3-6.5 \mathrm{pH})$ than FSS $\left(<45^{\circ} \mathrm{C}\right.$ and $\left.6.0-6.8 \mathrm{pH}\right)$. In 13 of the 14 springs, specific conductance varies from 1.31 to $18.76 \mathrm{mS} / \mathrm{cm}$. Agua Termal Sauceda (Sp. 4) is a distinct outlier, issuing from evaporite-bearing strata that are locally mined for salt. Sp. 4 has a specific conductance of $85.80 \mathrm{mS} / \mathrm{cm}$ (Table 1). All 14 springs are associated with surface mineralization, such as travertine and iron oxide precipitates (Fig. A1). 
Table 1. Spring and sample identification, location, and field parameters.

\begin{tabular}{cccccccc}
\hline Sp. & Name & $\begin{array}{c}\text { Elevation } \\
(\mathbf{m})\end{array}$ & Longitude & Latitude & $\mathbf{T}\left({ }^{\mathbf{O}} \mathbf{C}\right)$ & $\mathbf{p H}$ & $\begin{array}{c}\text { Cond. } \\
(\mathbf{m S} / \mathbf{c m})\end{array}$ \\
\hline $\mathbf{1}$ & Licapa & 4103 & -74.87776 & -13.36887 & 20.2 & 6.53 & 1.31 \\
$\mathbf{2}$ & Santo Tomás & 1693 & -72.94484 & -13.65254 & 39.9 & 6.12 & 11.31 \\
$\mathbf{3}$ & Ccónocc & 1850 & -72.63866 & -13.54313 & 31.8 & 6.84 & 3.26 \\
$\mathbf{4}$ & Agua termal Sauceda & 2308 & -72.49839 & -13.50098 & 27.8 & 6.16 & 85.80 \\
$\mathbf{5}$ & Baños termales Lares & 3281 & -72.05453 & -13.11067 & 45.4 & 5.96 & 7.17 \\
$\mathbf{6}$ & Baños de Upis & 4418 & -71.2752 & -13.75014 & 71.0 & 6.54 & 9.01 \\
$\mathbf{7}$ & Baños Pacchanta & 4308 & -71.24201 & -13.71736 & 54.2 & 5.96 & 3.27 \\
$\mathbf{8}$ & Aguas Calientes La & 4054 & -71.07299 & -14.45071 & 56.4 & 6.09 & 7.02 \\
$\mathbf{9}$ & Pichacani-Santa Rosa & 3931 & -70.75443 & -14.70899 & 16.6 & 6.15 & 6.76 \\
$\mathbf{1 0}$ & Baños Termales Collpa & 4106 & -70.14219 & -16.26762 & 54.0 & 5.98 & 4.82 \\
$\mathbf{1 1}$ & Aguas Calientes-Pinaya & 4386 & -70.88657 & -15.56674 & 80.5 & 6.15 & 15.16 \\
$\mathbf{1 2}$ & Aguas Calientes-Pinaya & 4379 & -70.88768 & -15.56689 & 68.5 & 6.09 & 14.61 \\
$\mathbf{1 3}$ & Aguas termales Crucero & 4572 & -70.11648 & -16.74175 & 62.0 & 5.98 & 18.76 \\
$\mathbf{1 4}$ & Punta Perdida- & 4614 & -70.08931 & -16.76263 & 43.2 & 5.31 & 6.29 \\
\hline
\end{tabular}

Major ion chemistry varies substantially in the 14 springs (Table 2); however, some distinct patterns emerge among FSS and BAS. Consistent with its high specific conductance, Sp. 4 exhibits very high concentrations of several geochemical constituents (Table 2; Table A1) and is omitted from the following comparisons. Overall the BAS are characterized by high salinity waters $\left(\mathrm{Na}^{+}=422-4616 \mathrm{ppm} ; \mathrm{Cl}^{-}=490-6931 \mathrm{ppm}\right)$, whereas the FSS are generally more dilute. However Sp. 2, located above the flat-slab segment, has the highest $\mathrm{HCO}_{3}{ }^{-}$and $\mathrm{Ca}^{2+}$ concentrations reported in this study (1751 ppm and $674 \mathrm{ppm}$ respectively). Concentrations of $\mathrm{SO}_{4}{ }^{2-}$ vary widely between the 14 springs with no distinction between FSS and BAS (19.5-975 ppm). Patterns and trends in major ion chemistry are visualized using a Piper diagram (Fig. 2A), modified to include symbols scaled to the concentration of total dissolved solids. As outlined above, the majority of BAS classify as $\mathrm{Na}-\mathrm{Cl}$ type waters, whereas FSS range from $\mathrm{Na}-\mathrm{Cl}$ type waters to $\mathrm{Ca}$ $\mathrm{HCO}_{3}$ and $\mathrm{Ca}-\mathrm{SO}_{4}$ water types. 
Table 2. Major ion concentrations (ppm) for the 14 spring. Ion balance was calculated with all relevant major and trace elements.

\begin{tabular}{|c|c|c|c|c|c|c|c|c|c|c|}
\hline $\begin{array}{l}\text { Sp. } \\
\text { MRL }\end{array}$ & $\begin{array}{l}\mathbf{C a}^{2+} \\
0.50\end{array}$ & $\begin{array}{c}\mathbf{M g}^{2+} \\
0.05\end{array}$ & $\begin{array}{l}\mathbf{N a}^{+} \\
0.40\end{array}$ & $\begin{array}{c}\mathbf{K}^{+} \\
0.13\end{array}$ & $\begin{array}{l}\mathrm{Cl}^{-} \\
0.1\end{array}$ & $\begin{array}{r}\mathbf{S O}_{4}{ }^{2-} \\
0.25\end{array}$ & $\begin{array}{l}\mathbf{N O}_{3}{ }^{-} \\
0.05\end{array}$ & $\mathrm{HCO}_{3}^{-}$ & $\mathbf{F}^{-}$ & $\begin{array}{c}\text { Ion Balance } \\
(\%)\end{array}$ \\
\hline 1 & 225 & 24.5 & 70.0 & 8.15 & 89.7 & 77.6 & $<0.10$ & 848 & 1.49 & -5 \\
\hline 2 & 674 & 96.3 & 1923 & 296 & 3096 & 354 & 0.98 & 1751 & 2.26 & 4 \\
\hline 3 & 295 & 88.0 & 381 & 9.95 & 614 & 912 & 0.24 & 223 & 1.70 & -2 \\
\hline 4 & 1649 & 182 & 16284 & $<130$ & 30023 & 1954 & $<3.5$ & 68 & 0.00 & -5 \\
\hline 5 & 585 & 138 & 894 & 100 & 1915 & 367 & $<0.10$ & 1330 & 2.10 & -1 \\
\hline 6 & 266 & 23.7 & 1498 & 263 & 2671 & 563 & $<0.20$ & 594 & 4.76 & -5 \\
\hline 7 & 263 & 19.5 & 422 & 54.0 & 490 & 832 & $<0.10$ & 532 & 3.93 & -7 \\
\hline 8 & 396 & 42.1 & 1256 & 123 & 1782 & 623 & $<0.10$ & 1015 & 3.56 & 1 \\
\hline 9 & 434 & 115 & 1158 & 69.5 & 1938 & 247 & $<0.20$ & 1454 & 2.57 & 0 \\
\hline 10 & 269 & 43.0 & 845 & 44.5 & 1159 & 561 & $<0.10$ & 643 & 2.13 & 0 \\
\hline 11 & 365 & 33.5 & 3350 & 183 & 5034 & 900 & $<0.50$ & 247 & 8.34 & 2 \\
\hline 12 & 357 & 33.4 & 3240 & 178 & 5014 & 975 & 3.50 & 229 & 8.76 & 0 \\
\hline 13 & 153 & 26.4 & 4616 & 386 & 6931 & 70.4 & $<0.50$ & 637 & 6.34 & 3 \\
\hline 14 & 73.1 & 5.73 & 1297 & 144 & 2174 & 19.5 & $<0.20$ & 198 & 3.03 & 0 \\
\hline
\end{tabular}
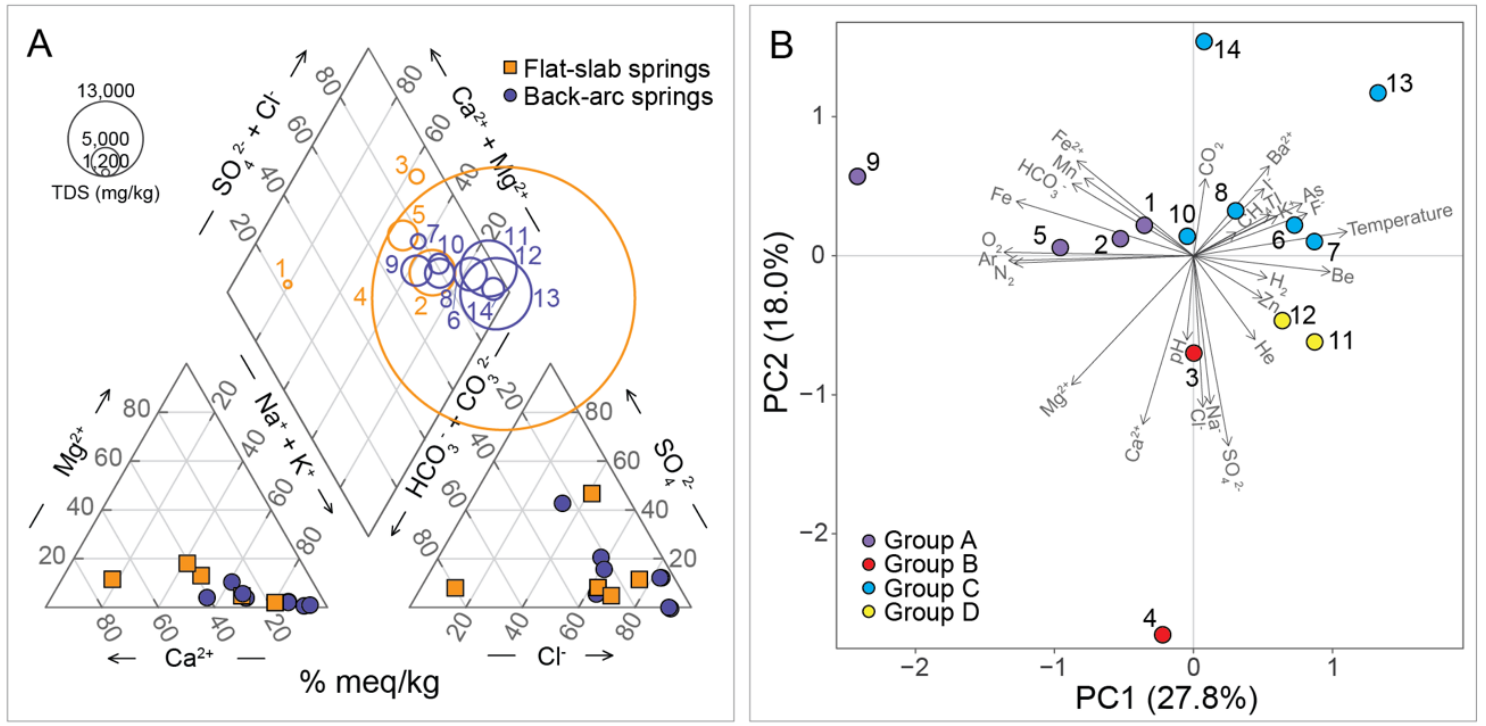

Figure 2. Geochemical trends for the thermal springs investigated. (A) Piper diagram with major element chemistry (Piper, 1944). Anions and cations come together in the central diamond to showcase dominant geochemical trends and ring size is correlated to total dissolved solids concentration (TDS, $\mathrm{mg} / \mathrm{kg}$ ). Note that $\mathrm{Sp} .4$ has significantly higher TDS than the other springs (see text for further explanation). (B) Principle component analysis (PCA) with geochemical parameters and spring temperature. Each vector represents a geochemical parameter and the vector direction is the relationship to the two principle components. Longer vector length indicates a stronger correlation and two vectors are correlated if the angle between them is $<90^{\circ}$. 
Concentrations of trace elements and dissolved gases vary among the 14 springs. Trace elements are more pronounced in BAS; specifically, As, Mn, and Ba concentrations are all notably higher in BAS than in FSS (Table A1). Dissolved gas chemistry $\left(\mathrm{CO}_{2}, \mathrm{CH}_{4}\right.$, $\mathrm{H}_{2}, \mathrm{~N}_{2}, \mathrm{O}_{2}, \mathrm{He}, \mathrm{Ar}$ ) is reported for 10 of 14 springs (Table A1), including two FSS (Sp. 2 and Sp. 5) and 8 BAS (Sp. 6-9 and Sp. 11-14). FSS gas chemistry is characterized by elevated $\mathrm{Ar}(0.0063-0.0066 \mathrm{mM})$ and $\mathrm{O}_{2}(0.0826-0.0896 \mathrm{mM})$ concentrations. In BAS higher concentrations of $\mathrm{CO}_{2}(6.1-19.5 \mathrm{mM}), \mathrm{He}(0.0058-0.6474 \mu \mathrm{M})$, and $\mathrm{CH}_{4}(0.0003-$ $0.1374 \mathrm{mM}$ ) are found, and $\mathrm{O}_{2}$ is much lower (as low as $0.0020 \mathrm{mM}$ ), compared to FSS. There is no distinction in $\mathrm{H}_{2}$ concentrations between FSS and BAS $(0.035-3.8374 \mu \mathrm{M})$.

PCA is used to identify geochemical groupings based on a more holistic composition by taking major ions, trace elements, and dissolved gases into consideration (Fig. 2B). The trace elements $\mathrm{Pb}, \mathrm{Ni}, \mathrm{Zn}, \mathrm{Cr}, \mathrm{Co}, \mathrm{Cu}, \mathrm{Se}, \mathrm{Sb}$ were detected in only one spring each, and are thus excluded from the PCA. The axes on the PCA represent the first two principle components, with principle component 1 explaining $28 \%$ of the variance in the dataset and principle component 2 explaining $18 \%$ of the variance. A PCA is considered good if the first two principle components explain the majority of the dataset's variance. For this PCA they explain 46\%. Vectors (arrows, Fig. 2B) represent each geochemical parameter and its relationship to principle components 1 and 2 . Two vectors are positively correlated if the angle between them is $<90^{\circ}$.

Four chemical groups emerged from the PCA analysis (colored groups in Fig. 2B) and follow a similar pattern to those outlined above. Groups A and B include the FSS, and Groups $\mathrm{C}$ and D comprise the BAS. Group A is characterized by the strong correlation between dissolved $\mathrm{N}_{2}, \mathrm{O}_{2}$, and Ar, and weaker correlation with total Fe. Group B is 
characterized by the correlation of major ions $\mathrm{Na}^{+}, \mathrm{Cl}^{-}$, and $\mathrm{Ca}^{2+}$. Group $\mathrm{C}$ is characterized by the correlation of $\mathrm{CO}_{2}$ and trace elements (i.e., As, Tl, and $\mathrm{Ba}$ ). Group D is characterized by the correlation of dissolved gas, such as $\mathrm{H}_{2}$ and $\mathrm{He}$.

\section{Geothermometry}

We use multiple geothermometers, specifically the Na-K-Ca, Na-K, and $\mathrm{K}-\mathrm{Mg}$ cation geothermometers, to estimate the temperature of subsurface geothermal fluids (RTEs) (Table A2). These estimates are based on the assumption of thermodynamic equilibrium at depth and the preservation of this equilibrium during flow to the surface (Fournier and Truesdell, 1973; Giggenbach, 1988). The Na-K-Ca geothermometer is an empirical thermometer and is most appropriate for surface fluids that contain high concentrations of $\mathrm{Ca}$, controlled by the solubility of carbonate in the spring water, and low concentrations of dissolved $\mathrm{CO}_{2}$ (Fournier and Truesdell, 1973; Giggenbach, 1988). The $\mathrm{Na}-\mathrm{K}$ geothermometer is based on empirical and thermodynamic data and is best suited for reservoir temperatures $>100^{\circ} \mathrm{C}$. Cation concentrations impact these two geothermometers. The Na-K-Ca geothermometer is most useful for surface fluids that satisfy the equation: $\log \left(\mathrm{Ca}^{1 / 2} / \mathrm{Na}\right)+2.06>1$; whereas the $\mathrm{Na}-\mathrm{K}$ geothermometer is best suited for concentrations such that $\log \left(\mathrm{Ca}^{1 / 2} / \mathrm{Na}\right)+2.06<1$ (Fournier and Truesdell, 1973). The K$\mathrm{Mg}$ geothermometer can accurately estimate reservoir temperatures for mature water chemistries; however, it re-equilibrates rapidly and can thus reflect cooling and mixing during fluid ascent through the crust (Fournier and Truesdell, 1973; Giggenbach, 1988).

In this study, the Na-K-Ca geothermometer returns the widest range of RTEs (40$\left.218^{\circ} \mathrm{C}\right)$, whereas the $\mathrm{Na}-\mathrm{K}$ thermometer estimates are hotter $\left(144-282^{\circ} \mathrm{C}\right)$, and the $\mathrm{K}-\mathrm{Mg}$ 
geothermometer gives, on average, cooler RTEs $\left(44-159^{\circ} \mathrm{C}\right)$ (Table A2). In general, the $\mathrm{Na}-\mathrm{K}-\mathrm{Ca}$ and $\mathrm{K}-\mathrm{Mg}$ geothermometers provide similar temperatures for cooler FSS, and $\mathrm{Na}-\mathrm{K}-\mathrm{Ca}$ and $\mathrm{Na}-\mathrm{K}$ are in close agreement for higher temperature BAS. Based on these observations and spring cation concentrations, the Na-K-Ca and $\mathrm{Na}-\mathrm{K}$ geothermometers are the most useful to estimate maximum subsurface geothermal fluid temperatures. The maximum RTEs for Sp. 1-10 and Sp. 11-14 are estimated with the Na-K-Ca and the NaK geothermometers, respectively. With respect to tectonic setting, RTEs, on average, yield lower temperatures for FSS $\left(40-193^{\circ} \mathrm{C}\right)$ compared to the BAS $\left(117-240^{\circ} \mathrm{C}\right)$. We note that springs located in the transition from the flat slab to backarc region (Sp. 6-9, Fig. 1) yield intermediate RTEs $\left(117-218^{\circ} \mathrm{C}\right)$.

\section{Molecular microbiology of spring systems}

A total of 53,479 unique $16 \mathrm{~S}$ rRNA gene OTUs were identified in planktonic and sediment communities sampled. This sequence dataset was subsampled for OTUs $\geq 1 \%$ abundance in at least one spring, resulting in 210 distinct OTUs (Table A3). These were described with respect to their homology to characterized taxa, and each comparison includes a calculated percent match to the known cultivar. In this way, each OTU was classified as novel ( $<97 \%$ match to described sequences) or previously characterized $(\geq$ 97\% match) (Fig. A2). Using this framework, 55\% of the high abundance ( $\geq 1 \%$ of total sequences in a given spring) OTUs are considered previously characterized and $45 \%$ are considered novel. Within the 14 springs, the abundances of dominant OTUs vary markedly, with some genera comprising up to $50 \%$ of the spring microbial community. 
Bacterial OTUs dominate the 14 springs (89.5\% abundance), followed by Archaeal OTUs (10\% abundance), and one unclassifiable OTU (Fig. A3A). These OTUs comprise 12 Bacteria phyla and two Archaea phyla (Fig. A3B). The three dominant bacterial phyla include Bacteroidetes, Firmicutes, and Proteobacteria, representing $46 \%$ of the high abundance OTUs. Proteobacteria is the dominant Bacteria phyla (24\%) regardless of any further subsampling (i.e., planktonic versus sediment community), and includes Alpha-, Beta-, Gamma-, Delta-, and Zeta-proteobacteria classes. Two archaeal classes were identified, Nitrososphaerales and Thermoprotei (Fig. A3C), and are only present in BAS. Thermoprotei represents the majority of the OTUs in Sp. 11 (63\%) and are only identified in this spring. OTUs affiliated with phototrophic microbes were identified in each of the 14 springs and include bacterial (Cyanobacteria) and algal (Chloroplast) populations. Putatively phototrophic OTUs comprise $12 \%$ of the dataset and are represented by as much as $28 \%$ of the high abundance OTUs in these springs.

To identify factors that may explain differences in the composition of microbial communities across the studied springs, class-level abundances of communities were compared to spring temperature (Fig. 3). There are five microbial classes that only appear in springs $>45{ }^{\circ} \mathrm{C}$ : Anaerolineae, Ignavibacteria (with the exception of $1.5 \%$ of the sediment fraction of Sp. 2), Deinococci, Nitrososphaerales (with the exception of $1 \%$ of the sediment fraction of Sp. 14), and Thermoprotei. The classes Zetaproteobacteria and Spirochaetia are not present above $25{ }^{\circ} \mathrm{C}$. With the exception of $2 \%$ of the planktonic fraction of Sp. 6, algal chloroplasts are also not detected in springs with temperatures above $25^{\circ} \mathrm{C}$. 


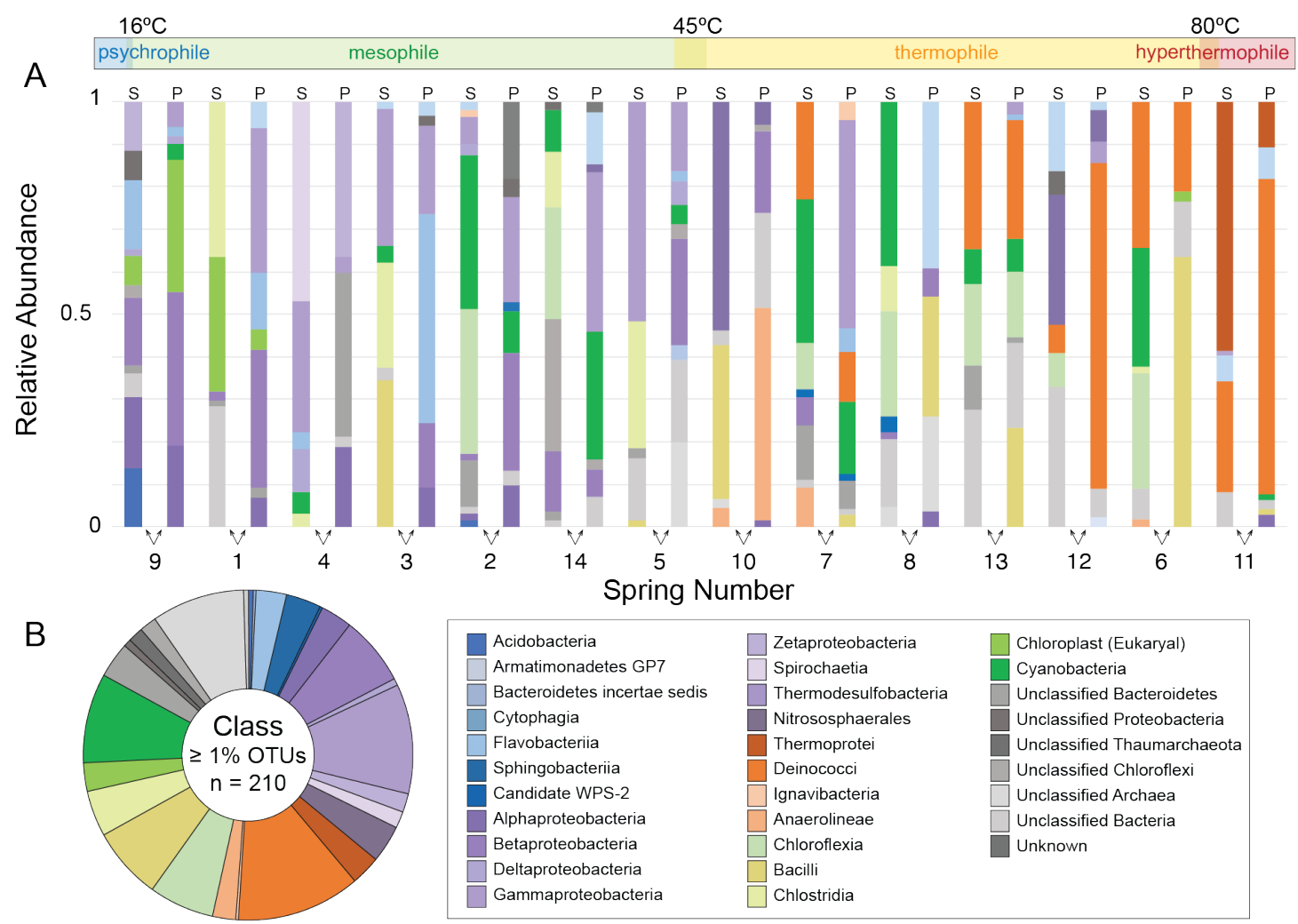

Figure 3. Microbial community taxonomic data at the class level for operational taxonomic units (OTUs) that represent $\geq 1 \%$ relative abundance in at least one of the 14 springs. (A) Bar chart showing relative abundance of classes in each spring, including the sediment (S) and planktonic $(\mathrm{P})$ communities. The springs are arranged from low to high temperature. (B) Donut chart displaying the composite distribution of Classes within all 14 springs. The key and color-coding applies to both charts and is rudimentarily based on inferred metabolism or another key characteristic of the Class. Purple represents dominantly chemotrophic species, orange signifies thermophiles, green shows dominantly phototrophs, blue represents general Bacteria, yellow represents Archaea, and grey signifies unknown or unclassified sequences.

NMDS ordinations for A) the entire dataset $(n=53,479)$, B) sequences $\geq 0.1 \%$ abundance $(n=765)$, and $C)$ sequences $\geq 1 \%$ abundance $(n=210)$ return a stress of 0.14 (ideal fit if $\leq 0.05$, poor fit if $\geq 0.2$; Buttigieg and Ramette, 2014), which is considered good fit. For the purpose of this analysis, we will use the NMDS ordination with all sequences (Fig. 4A). Springs that plot close together on the NMDS have more sequences in common than springs that plot farther apart. The tightest cluster on the NMDS is a group of BAS 
(Sp. 6, 7, 8, 10, 13, 14), which corresponds to PCA Group C, indicating that these springs also have similar chemistries. The program ANOSIM statistically determines the similarity of sample communities in pre-defined groups, here outlined by observations of spring characteristics and geographic location (groups as polygons in Fig. 4B-D). Microbial communities cluster around temperature $(P<0.001$ and R statistic $=0.5)$, chemistry $(P<$ 0.001 and $\mathrm{R}$ statistic $=0.6$ ), and the two tectonic setting groups (flat slab verses backarc) $(P<0.001$ and $\mathrm{R}$ statistic $=0.5)$. These general patterns withstand regardless of which groups of springs (i.e. subsampled springs) are included in the NMDS analysis (Fig A4, Table A4). 

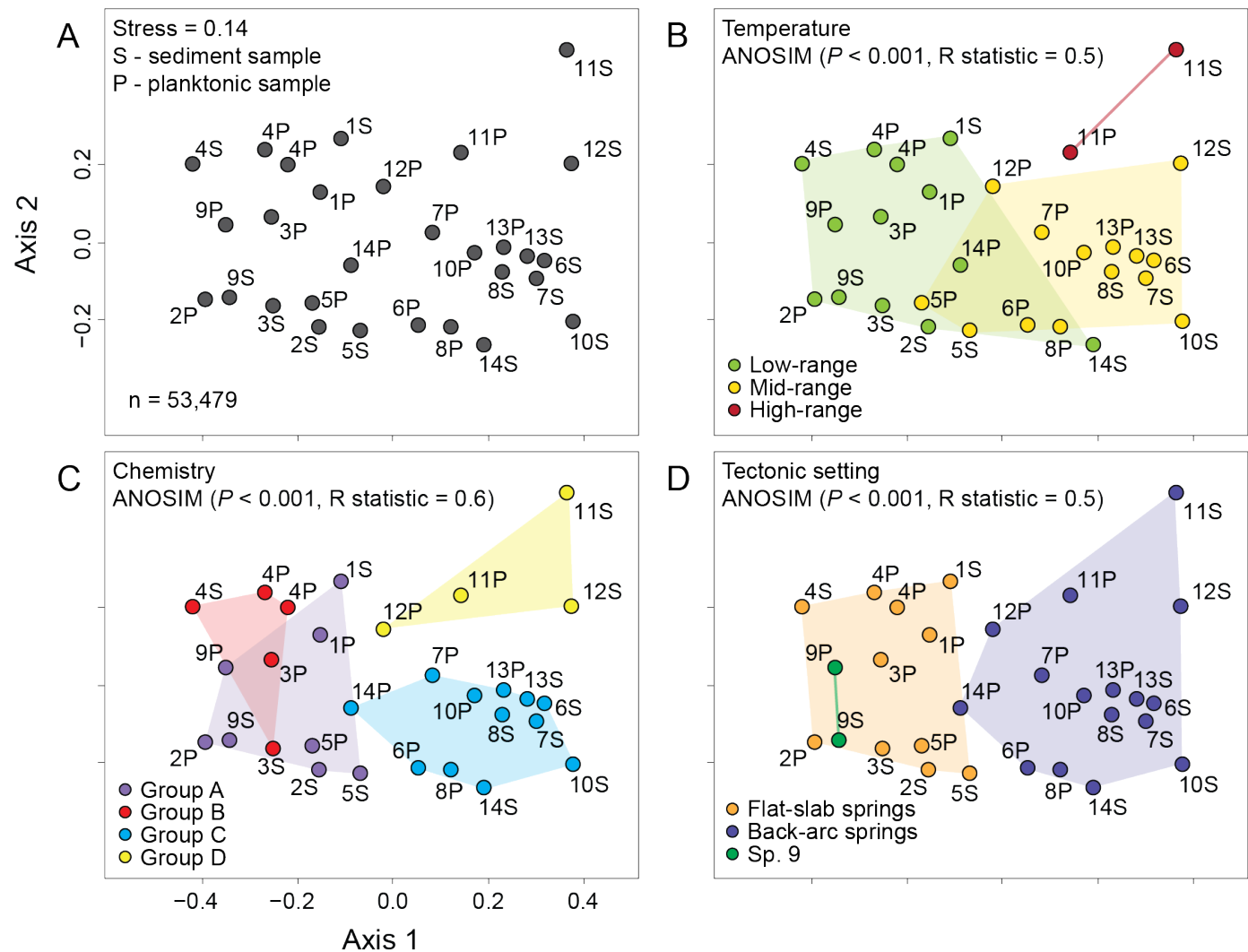

Figure 4. (A) Non-metric multidimensional scaling (NMDS) ordination based on BrayCurtis dissimilarity for all OTUs in the 14 springs $(n=53,489)$, including both the sediment (S) and planktonic (P) microbial communities. The stress for this ordination is 0.14 . Springs that plot close together have more species in common than those that plot far apart. Three observational treatments are overlain on the ordination and are supported by ANOSIM (see text for details): (B) microbial temperature classifications ( $\mathrm{R}$ statistic $=0.5$ ), $(C)$ PCA geochemistry groups $(\mathrm{R}$ statistic $=0.6)$, and $(\mathrm{D})$ tectonic setting $(\mathrm{R}$ statistic $=0.5)$.

\section{DISCUSSION}

\section{Geochemistry of spring systems}

Our data spans the transition from an amagmatic flat-slab subduction setting to an active backarc. Spring geochemical and statistical trends highlight cooler and chemically heterogenous FSS, and metal-rich, gas-rich, and more geochemically variable BAS (Table 2; Table A1). Springs in both settings are carbonic with $f_{\mathrm{CO} 2}\left(\sim \mathrm{P}_{\mathrm{CO} 2}\right)$ that ranges from $10^{-}$ 1.8 to $10^{-0.3} \mathrm{~atm}$. We note that all but one BAS issue gas bubbles at their source and are 
primarily $\mathrm{CO}_{2}(1.4-47.9 \%)$ based on dry gas data (Table A1). High volatile content in the backarc is consistent with influences from recent magmatism (11-6 ka flows) and possibly high heat flow (Henry and Pollack, 1988; Global Volcanism Program, 2013). The subsurface geology provides a source for metals (e.g., As and Fe) and the deep circulation of hot, $\mathrm{CO}_{2}$-rich, likely reducing groundwater aids in chemical alteration and mobilization of these ions. High subsurface temperatures and a long flow path will increase the concentrations of ions at the surface. BAS generally have higher concentrations of $\mathrm{Na}^{+}$, $\mathrm{K}^{+}$, total $\mathrm{Fe}, \mathrm{Ba}$, and $\mathrm{As}$, indicative of water-rock interaction during fluid flow and interaction with relatively young volcanic rocks (Hilton et al., 1996; Arnold et al., 2017). Conversely, FSS show a wider variety of dominant chemistry types (including $\mathrm{Ca}, \mathrm{HCO}_{3}$, and $\mathrm{Na}-\mathrm{Cl}$ waters types) (Fig. 2A), reflecting shallow groundwater mixing, subsequently less high temperature water-rock interaction at greater depth, and partial re-equilibration with the variable near surface rock types.

Geochemically diverse FSS and saline-rich BAS are consistent with RTE patterns, geothermometry estimates, and flow path depth interpretations. RTEs inform fluid circulation depths, fluid maturity, and water-rock interaction (Fournier and Truesdel, 1973). The degree of agreement between the different geothermometers helps inform the extent of fluid-rock interaction. Disparity between temperature estimates implies less water-rock interaction at depth and fluid "immaturity" (Fig. 5). Springs with this signature likely cooled and re-equilibrated since traveling from the reservoir to the surface, and have since mixed with shallow, cooler groundwater (Fournier and Truesdell, 1973). Agreement or partial agreement between geothermometers is generally associated with higher RTEs. These fluids are termed "mature" and suggest a higher degree of water-rock interaction due 
to hotter fluids. These fluids also reflect preservation of the primary geothermal fluid and the RTEs are likely more representative of fluid temperatures at depth (Giggenbach, 1988).

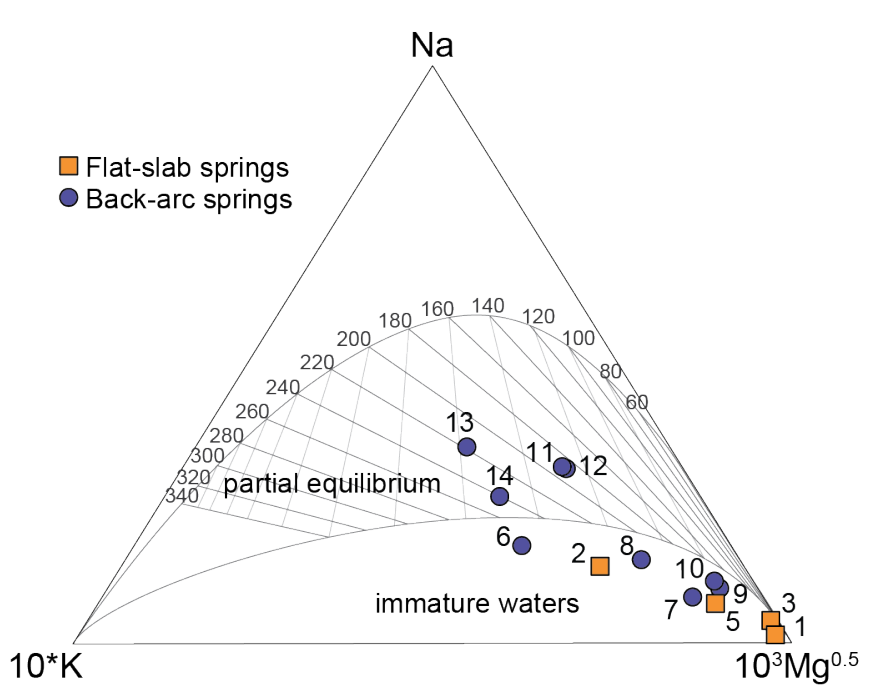

Figure 5. Ternary diagram for the $\mathrm{Na}-\mathrm{K}$ and $\mathrm{K}-\mathrm{Mg}$ geothermometers, modified from Giggenbach (1988). This diagram reflects the extent of water-rock interaction at depth and "immature" fluid signatures indicate re-equilibration since travel to the surface and groundwater mixing. Sp. $1-10$ plot as "immature" waters. Sp. 11-14 are in partial equilibrium suggesting they have experienced less mixing and the geothermometry estimates for these springs are more representative of temperatures at depth.

Our RTEs support the observation that the transition from amagmatic flat-slab subduction into the active backarc is expressed geochemically in crustal fluids accessed at host springs. For example, Sp. 1-10 are "immature" waters (and include the transitional BAS), whereas Sp. 11-14 show partial equilibration between geothermometers and host more "mature" waters (Fig. 5), suggesting RTEs for these springs may be representative of maximum temperatures at depth. Using the average RTEs for FSS (40-193 $\left.{ }^{\circ} \mathrm{C}\right)$ and BAS $\left(117-240{ }^{\circ} \mathrm{C}\right)$, an average geothermal gradient of $25^{\circ} \mathrm{C} / \mathrm{km}$, and surface temperature of 0 ${ }^{\circ} \mathrm{C}$, we estimate circulation depths of $\sim 4.2 \mathrm{~km}$ in the flat-slab region, and $\sim 7.2 \mathrm{~km}$ in the backarc. Broadly, this shows the BAS likely have deeper flow paths and a deeper waterrock interaction signal is preserved compared to FSS (Fig. 6). We note that constraints on 
the geothermal gradient are not available, and it is possible that recent magmatism in the backarc requires the use of a higher gradient $\left(30\right.$ to $35^{\circ} \mathrm{C} / \mathrm{km}$ ), which will lower the fluid circulation depth estimates (5.8 and $4.9 \mathrm{~km}$, respectively).

Pichacani-Santa Rosa (Sp. 9) is a distinct outlier among BAS (Fig. 3 and Fig. 4D), exhibiting temperature and chemical similarities to some of the FSS. This spring is the coolest $\left(16.6^{\circ} \mathrm{C}\right)$ of the 14 investigated, vigorously bubbles $\mathrm{CO}_{2}$-rich gases, emanates from a travertine spring mound near the Rio Santa Rosa, and lies along a large inferred fault (De La Cruz, 1995). The spring exhibits a regular fluctuation of water level and bubbling intensity ( $\sim 20$-minute cycles) reminiscent of other documented $\mathrm{CO}_{2}$-geysers (Keating et al., 2010; Han et al., 2013). The $\mathrm{CO}_{2}$ flux at this spring likely reflects a deep source that could be related to magmatism or a crustal origin (e.g., natural gas, carbonate decarbonation). However, compared to other BAS, the flow path for Sp. 9 is either shallower or significantly modified by groundwater mixing as evidenced by cooler RTEs (Na-K-Ca: $127^{\circ} \mathrm{C} ; \mathrm{K}-\mathrm{Mg}: 85^{\circ} \mathrm{C}$ ). This spring illustrates that in addition to the subduction style, local structural and geological controls are important when addressing factors affecting the overall system. 


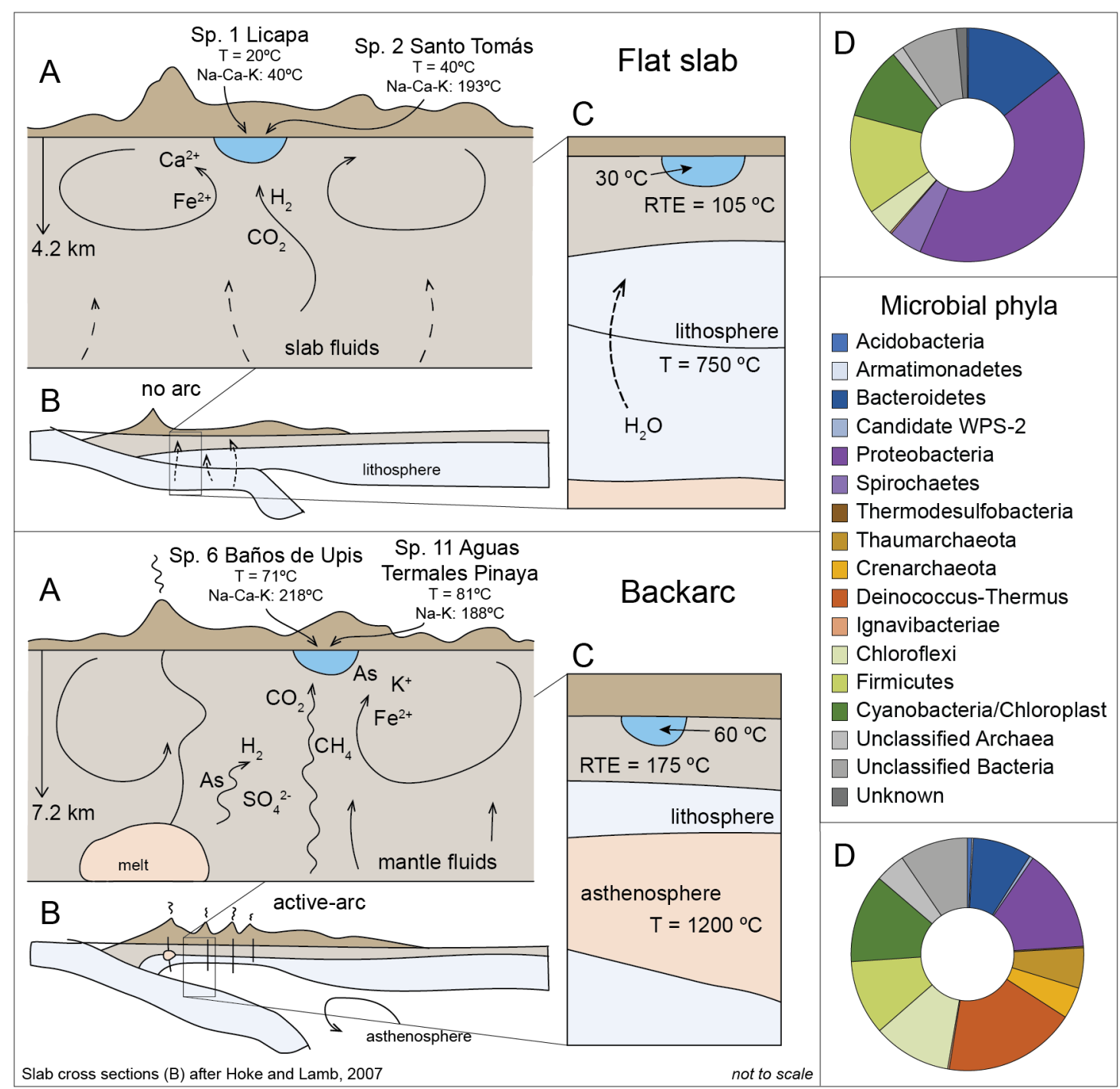

Figure 6. Schematic cross-sections and microbial breakdown for the flat-slab (left) and backarc (right) settings. (A) Key characteristics and differences between the two tectonic settings are highlighted, such as fluid circulation depth and volatile contributions impacting fluid-rock interaction and microbial respiration. Notably for the flat slab, there are shallower flow paths and influence from slab-derived fluids. In the backarc, fluid circulation depth is deeper and there is more intense water-rock interaction due to recent magmatism providing heat and volatiles. Each cross-section contains information on representative springs. Spring surface and subsurface temperature is highlighted to show generally lower temperatures in the flat slab compared to the backarc. The indicated ion concentrations are some of the highest in the study area and are possible energy sources used for microbial metabolism. (B) Schematic of the slab angle associated with each setting (after Hoke and Lamb, 2007). (C) Zoomed view of subduction style. Average surface water temperatures, RTEs, and deep subsurface temperatures are shown. (D) The donut charts (made with the same rudimentary color-coding as Fig. 3) indicate that the backarc is more microbially diverse than the flat slab which is dominated by Proteobacteria $(42 \%)$. The phylum "Cyanobacteria/ Chloroplast" contains 2.8\% Eukaryal chloroplast. Cross-sections (A \& B) are not to scale. 
We speculate that thermal springs in the back-arc region are fed through deeper, warmer flow paths than in the flat-slab region (Fig. 6). This is due, in part, to the tectonic history of southern Peru and the Altiplano, which has experienced recent and ongoing magmatism since $\sim 22 \mathrm{Ma}$ and includes Pliocene-Quaternary activity (Hoke and Lamb, 2007; Ramos and Folguera, 2009; Chapman et al., 2015). The magmatic influences in the backarc cause higher heat flow, at least locally, that result in deeper fluid circulation and the advection of hot, saline fluids towards the surface. These processes are associated with higher temperature subsurface fluids (estimated by RTEs), higher observed spring temperatures, and the relatively uniform $\mathrm{Na}-\mathrm{Cl}$ water type. The younger magmatism also adds volatiles and metals (e.g., $\mathrm{CO}_{2}, \mathrm{~S}$ species, As) to the system (Arnold et al., 2017), reflected in the surface gas and water geochemistry.

In contrast, the flat-slab region has lower RTEs and spring temperatures that imply less heat flow and/or more shallowly circulated fluids than in the backarc. This results in a wide range of water types and salinities that are indicative of near-surface water-rock reequilibration and groundwater mixing. The flat-slab geometry has ultimately shut off the magmatic volatiles and heat from melt, but fluids are still circulating (Fig. 6), albeit at shallower depths and cooler temperatures. However, FSS do contain some volatiles (e.g., $\mathrm{CO}_{2}, \mathrm{H}_{2}$ ), which could be associated with deep-seated decarbonation reactions and possibly mobilized by the migration of slab-derived fluids, which are consistent with observations elsewhere along the Peruvian flat slab (Newell et al., 2015; Scott et al., 2020). 


\section{Microbial community ecology and connections to tectonic setting}

We propose that subduction style and magmatic activity influence the geochemistry and temperature of thermal springs which, in turn, shape the diversity of nutrients available to cultivate various communities of microorganisms in these environments. Sustained disequilibrium of electron donor and acceptor pairs, resulting in part from the flux of deeply-circulated reducing fluids mixing with more oxic surface waters, supports microbial metabolism in the 14 springs. NMDS ordination (Fig. 4) reflects the link between microbiology and environment, exhibiting clusters of springs that correspond to physiochemical groups. For instance, a NMDS cluster of BAS correlates to Group C from the PCA, suggesting a correlation between chemistry and community diversity for these specific springs. Our ANOSIM results give high R statistics for groups based on the flatslab and back-arc tectonic settings $(\mathrm{R}=0.5)$, the PCA analysis $(\mathrm{R}=0.6)$, and spring temperature $(\mathrm{R}=0.5)$. There is minimal overlap between tectonic style groups on the NMDS (colored polygons in Fig. 4D), suggesting that the microbial communities are distinctly different between but similar within these groups. Minimal overlap is observed for chemistry and temperature groups as well (Fig. 4B-C). Thus, the FSS and BAS contain entirely different phyla, despite the 14 springs containing a range of phototrophic and chemotrophic taxa.

We speculate the putative function of OTUs ( $\geq 1 \%$ abundance, in at least one spring) based on similarity to known cultivars and use spring inorganic geochemistry to discuss whether the microbial function reflects the observed chemistry of the environment (Colman et al., 2016; Rempfert et al., 2017). Microbial community differences between the FSS and BAS can be explained, in part, by the metabolic attributes of the organisms 
responding to the given chemical components and temperatures of each habitat. Mesophilic springs located in the flat-slab region are dominated by Proteobacteria ( $52 \%$ of identified OTUs) with Alpha-, Beta-, Delta-, Gamma-, and Zeta- proteobacteria represented, highlighting the metabolic diversity of the phylum. This also reflects the variable spring chemistry in the flat slab where groundwater mixing results in water types that are $\mathrm{Na}-\mathrm{Cl}$, $\mathrm{Ca}-\mathrm{HCO}_{3}$, and $\mathrm{Ca}-\mathrm{SO}_{4}$ type waters (Fig. 2A). In contrast, the microbial composition of BAS are dominantly controlled by temperature and to a lesser extent geochemistry. In these springs $\mathrm{SO}_{4}$-reducing organisms and high temperature tolerant microorganisms dominate (29\% of OTUs) and reflect an increase of volatiles and heat to the backarc spring systems. There is also a wider variety of phyla in the communities of BAS compared to those of the FSS (Fig. 6C). Notable OTUs found in BAS are affiliated with Thermaceae, Desulfurococcaceae, Rhodothermaceae, Nitrososphaera, Ignavibacteriaceae, and Thermodesulfobacteriaceae. In this study, the family Thermaceae is the most prevalent family, and is found in abundance (11-50\% abundant) in 5 of the 6 hottest springs (54-81 ${ }^{\circ} \mathrm{C}$ ) in the backarc (Table 3). 


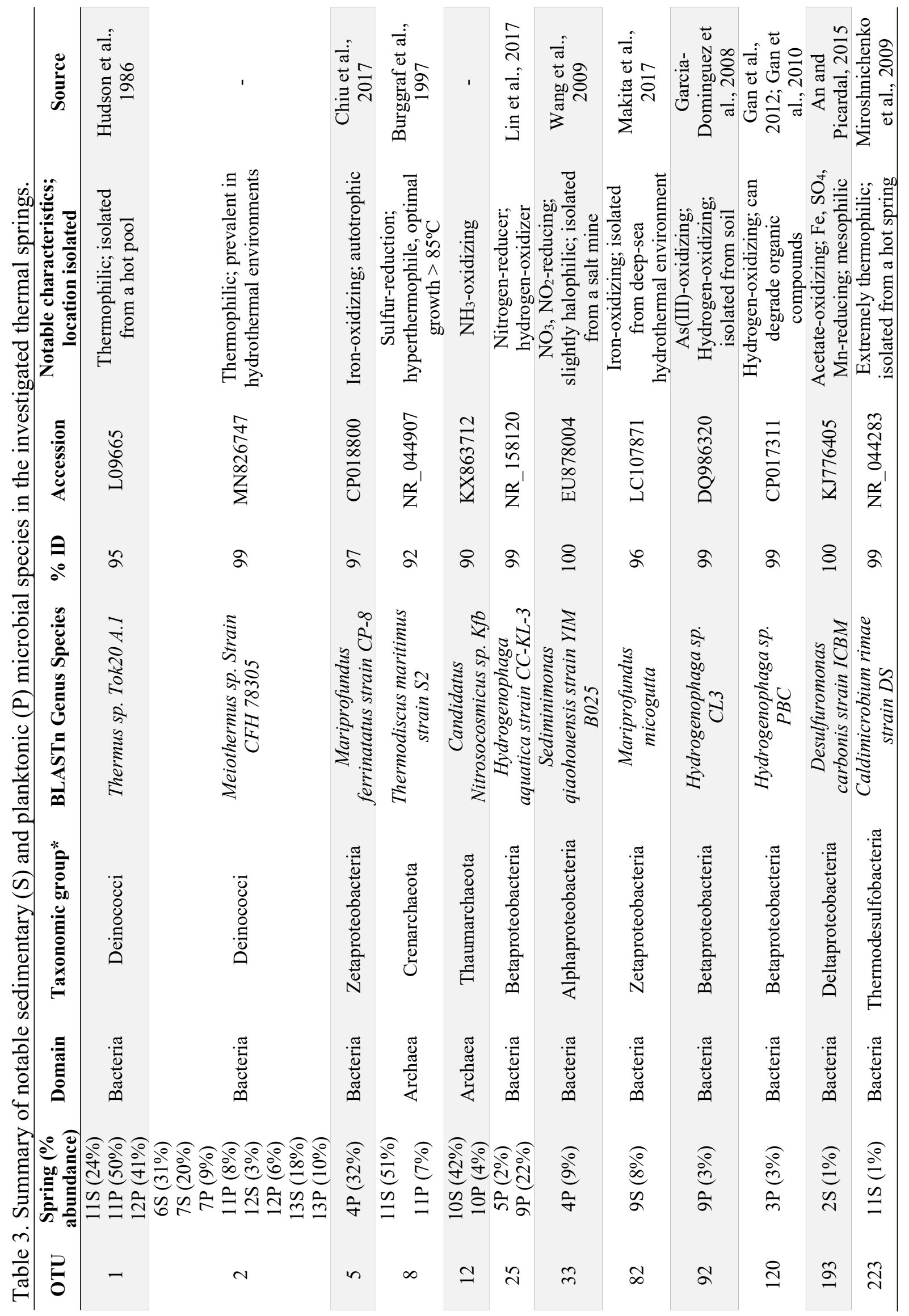


The diverse chemistry of FSS is reflected in their microbial communities. For example, genera of Comamonadaceae (i.e., Hydrogenophaga) are present in, and dominate the community of, Sp. 3, 5, and 9 (up to $22 \%$ abundant). The presence of Comamonadaceae in these springs is consistent with the demonstrated ability of Hydrogenophaga to oxidize $\mathrm{H}_{2}$ (Willems and Gillis, 2005). Sp. 5 and 9 contain appreciable amounts of dissolved $\mathrm{H}_{2}$ (1.17 and $0.075 \mu \mathrm{M}$, respectively), and although $\mathrm{H}_{2}$ was not detected in Sp. 3, it is likely still present at very low levels and is used as a nutrient. Genera of Desulfomonadales (i.e., Desulfuromonas) are characterized by facultative $\mathrm{Fe}$ and $\mathrm{S}$ respiring microbes (Kuever et al., 2005). The presence of Desulfuromonas carbonis in the sediment fraction of Sp. 2 is consistent with the spring's elevated concentration of reduced $\mathrm{Fe}\left(4.95 \mathrm{ppm} \mathrm{Fe}{ }^{2+}\right)$. The halophilic microbial strain Sediminimonas qiaohouensis strain YIM B025 (phylum Proteobacteria) was isolated from a salt mine and is present in the planktonic fraction of Sp. 4 (100\% ID match; Table 3). Sp. 4 has a very high concentration of $\mathrm{Cl}^{-}(>30,000 \mathrm{ppm})$, reflecting the circulation of spring fluids through evaporite deposits, suggesting that local bedrock geology also contributes to community diversity.

The phylum Thermodesulfobacteria represents a group of hyperthermophilic, sulfate-reducing microorganisms generally isolated from Yellowstone National Park (YNP) and other hydrothermal systems (Garrity et al., 2001). An OTU most closely related to Caldimicrobium rimae (99\% ID match) was found in Sp. 11, the BAS with the highest measured surface temperature $\left(80.5^{\circ} \mathrm{C}\right)$ and one of the highest $\mathrm{SO}_{4}{ }^{2-}$ concentrations (900 ppm), a characteristic component of magmatically controlled hydrothermal systems. Sp. 11 also contains an OTU belonging to the sulfur-reducing family Desulfurococcaceae (phylum Crenarchaeota; Huber and Stetter, 2001) and is most closely related to 
Thermodiscus maritimus (99\% ID match). This is the most abundant OTU in any one spring $(51 \%$ of Sp. 11$)$ of the study area.

We suggest that the distinct differences in geomicrobiology between FSS and BAS fundamentally reflect the subduction style and associated processes. The dominant factors impacting spring geomicrobiology are the flux of deeply circulated fluids to the surface, the extent of water-rock interaction along flow-paths, and ultimately the system temperature. Although local and regional rock types can impact nutrient availability (Rempfert et al., 2017), it is unlikely to be the dominant controlling factor here. It is well documented that microbial communities respond to gradients in temperature, chemistry, and acidity in places such as YNP (e.g., Brock, 1967; Shock et al., 2010; Inskeep et al., 2015; Colman et al., 2018) and along the Costa Rican convergent margin (Fullerton et al., 2019). These systems are influenced by a nearby volcanic presence that dominates the spring chemistry and thus microbial community ecology. Here, we show that despite a lack of a volcanic influence diverse niches of microbial communities still develop and likely give a clearer picture of the underlying system controls. The distinct geomicrobiological differences between the FSS and BAS indicate the importance of the subducting slab angle at convergent margins on the regulation of temperature and chemistry that ultimately shapes surface environments.

\section{SUMMARY AND CONCLUSIONS}

To evaluate the tectonic controls on thermal system microbial diversity, we quantify the linkages between geochemistry and microbial ecology in continental thermal springs along a traverse from the amagmatic flat-slab subduction segment to the active 
back-arc region in south-central Peru. Aqueous and gas geochemistry and molecular microbiological sequence data was collected from 14 thermal springs. General trends show that FSS geochemistry is more variable with lower total dissolved solids (with some exceptions) than those in the backarc. BAS chemistry shows exclusively higher salinity, $\mathrm{Na}-\mathrm{Cl}$ type waters with higher concentrations of volatiles such as $\mathrm{CO}_{2}$ and $\mathrm{S}$ species. This is reflective of a magmatic influence, imparting more heat to the backarc. The microbial communities that develop in the FSS and BAS are reflective of the dominant chemistry and temperature signatures of each environment. The dominant phyla in FSS microbial communities is Proteobacteria ( $46 \%$ of sequences), including two springs that contain ironoxidizing Zetaproteobacteria. There is a wider variety of phyla in BAS, however microbes in these environments respond to temperature more dominantly then chemistry, reflected by thermophilic taxa including Crenarchaeota (4\%) and Deinococcus-Thermus (18\%).

The geochemical differences between the two settings suggest different flow paths, flux of volatiles from depth, and degrees of water-rock interaction that we argue are ultimately controlled by the subducting slab angle, and the presence or absence of asthenosphere in contact with the continental lithosphere. Recent magmatism in the backarc fosters deeper and higher temperature flow paths, a greater amount of water-rock interaction, higher spring temperatures, and an influx of volatiles. In contrast, the flat slab region has limited heat flow and no present-day magmatism; as such, fluids spend less time in the subsurface along shallower flow-paths with more near-surface water-rock-aquifer interaction. There is likely still mantle to crust fluid transfer in the flat-slab region (e.g., Newell et al., 2015), which may help explain the high $\mathrm{CO}_{2}$ content of some springs over the flat slab. 
Statistically significant relationships between spring chemistry and temperature and microbial communities suggest a strong connection of spring physicochemical parameters to diversity. The relationship between spring microbial community and tectonic setting (flat slab verses backarc) is also significantly different, where FSS contain a different set of phyla than BAS. We suggest tectonic setting regulates the amount and variety of nutrients available for microbial metabolism by controlling subsurface processes (i.e., extent of water-rock interaction and temperatures of fluids at depth). Redox disequilibrium, created when deep reducing fluids mix with oxidizing groundwater, fosters diverse and geochemically reflective communities at the surface. We note that the springs southwest of Cusco (Sp. 6-9) are located where the slab angle is transitioning from flat to steep (Hayes, 2018). Based on observed and statistical overlaps in the geochemistry and microbiology of these springs, we suggest that gradients in tectonic setting also strongly influence the geomicrobiology of continental thermal springs. 


\section{REFERENCES}

Abbott, D., Brury, R., and Smith, W.H.F., 1994, Flat to steep transition in subduction style: Geology, v. 22, p. 937-940.

Allmendinger, R.W., Jordan, T.E., Kay, S.M., and Isacks, B.L., 1997, The evolution of the Altiplano-Puna plateau of the central Andes: Annu. Rev. Earth Planet. Sci, v. 25, p. $139-74$.

Amend, J.P., McCollom, T.M., Hentscher, M., and Bach, W., 2011, Catabolic and anabolic energy for chemolithoautotrophs in deep-sea hydrothermal systems hosted in different rock types: Geochimica et Cosmochimica Acta, v. 75, p. 5736-5748, doi: 10.1016/J.GCA.2011.07.041.

Amend, J.P., and Teske, A., 2005, Expanding frontiers in deep subsurface microbiology: Paleogeography, Paleoclimatology, Paleoecology, v. 219, p. 131-155, doi: 10.1016/j.palaeo.2004.10.018.

An, T.T., and Picardal, F.W., 2015, Desulfuromonas carbonis sp. nov., an Fe (III)-, S- and Mn (IV)-reducing bacterium isolated from an active coalbed methane gas well: International Journal of Systematic and Evolutionary Microbiology, v. 65, p. 16861693, doi: 10.1099/ijs.0.000159.

Antonijevic, S.K., Wagner, L.S., Kumar, A., Beck, S.L., Long, M.D., Zandt, G., Tavera, H., and Condori, C., 2015, The role of ridges in the formation and longevity of flat slabs: Nature, v. 524, p. 212-215, doi: 10.1038/nature14648.

Arnold, Y. Peralta, Cabassi, J., Tassi, F., Caffe, P.J., and Vaselli, O., 2017, Fluid geochemistry of a deep-seated geothermal resource in the Puna plateau (Jujuy Province, Argentina): Journal of Volcanology and Geothermal Research, v. 338, p. 121-134, doi: 10.1016/j.jvolgeores.2017.03.030.

Baioumy, H., Nawawi, M., Wagner, K., and Arifin, M.H., 2015, Geochemistry and geothermometry of non-volcanic hot springs in West Malaysia: Journal of Volcanology and Geothermal Research, v. 290, p. 12-22, doi: 10.1016/j.jvolgeores.2014.11.014.

Barry, P.H., de Moor, J.M., Giovannelli, D., Schrenk, M., Hummer, D.R., Lopez, T., Pratt, C.A., Segura, Y.A., Battaglia, A., Beaudry, P., Bini, G., Cascante, M., D’Errico, G., di Carlo, M., et al., 2019, Forearc carbon sink reduces long-term volatile recycling into the mantle: Nature, v. 568, p. 487-492, doi: 10.1038/s41586-019-1131-5.

Bethke, C., 2008, Geochemical and biogeochemical reaction modeling: Cambridge University Press, p. 1-543. 
Boone, D.R., Castenholz, R.W., and Garrity, G.M. (Eds.), 2001, Bergey’s Manual® of Systematic Bacteriology: Springer New York, v. 1, doi: 10.1007/978-0-387-21609-6.

Boyd, E.S., Jackson, R.A., Encarnacion, G., Zahn, J.A., Beard, T., Leavitt, W.D., Pi, Y., Zhang, C.L., Pearson, A., and Geesey, G.G., 2007, Isolation, characterization, and ecology of sulfur-respiring crenarchaea inhabiting acid-sulfate-chloride-containing geothermal springs in Yellowstone National Park.: Applied and environmental microbiology, v. 73, p. 6669-6677, doi: 10.1128/AEM.01321-07.

Boyd, E.S., Fecteau, K.M., Havig, J.R., Shock, E.L., and Peters, J.W., 2012, Modeling the Habitat Range of Phototrophs in Yellowstone National Park: Toward the Development of a Comprehensive Fitness Landscape: Frontiers in Microbiology, v. 3, p. 221, doi: 10.3389/fmicb.2012.00221

Boyd, E.S., Schut, G.J., Adams, M.W.W., and Peters, J.W., 2014, Hydrogen Metabolism and the Evolution of Biological Respiration: Microbe Magazine, v. 9, p. 361-367, doi: 10.1128/microbe.9.361.1.

Brock, T.D., 1967, Yellowstone Thermal Biology View project: Science, v. 158, p. 10121019, doi: 10.1126/science.230.4722.132.

Burgess, E.A., Unrine, J.M., Mills, G.L., Romanek, C.S., and Wiegel, J., 2012, Comparative Geochemical and Microbiological Characterization of Two Thermal Pools in the Uzon Caldera, Kamchatka, Russia: Microbial Ecology, v. 63, p. 471-489, doi: 10.1007/s00248-011-9979-4.

Burggraf, S., Huber, H., and Stetter, K.O., 1997, Reclassification of the Crenarchaeal Orders and Families in Accordance with 16S rRNA Sequence Data: International Journal of Systematic Bacteriology, v. 47, p. 657-660.

Buttigieg, P.L., and Ramette, A., 2014, A guide to statistical analysis in microbial ecology: a community-focused, living review of multivariate data analyses: FEMS Microbiology Ecology, v. 90, p. 543-550, doi: 10.1111/1574-6941.12437.

Cabrera, J., Sébrier, M., and Mercier, J.L., 1991, Plio-Quaternary geodynamic evolution of a segment of the Peruvian Andean Cordillera located above the change in the subduction geometry: the Cuzco region: Tectonophysics, v. 190, p. 331-362.

Carlier, G., Lorand, J.P., Liégeois, J.P., Fornari, M., Soler, P., Carlotto, V., and Cárdenas, J., 2005, Potassic-ultrapotassic mafic rocks delineate two lithospheric mantle blocks beneath the southern Peruvian Altiplano: Geology, v. 33, p. 601-604, doi: 10.1130/G21643.1. 
Chapman, A.D., Ducea, M.N., McQuarrie, N., Coble, M., Petrescu, L., and Hoffman, D., 2015, Constraints on plateau architecture and assembly from deep crustal xenoliths, northern Altiplano (SE Peru): Bulletin of the Geological Society of America, v. 127, p. 1777-1797, doi: 10.1130/B31206.1.

Chiu, B.K., Kato, S., Mcallister, S.M., Field, E.K., Chan, C.S., and Chan, C.S., 2017, Novel Pelagic Iron-Oxidizing Zetaproteobacteria from the Chesapeake Bay Oxic - Anoxic Transition Zone: Frontiers in Microbiology, v. 8, doi: 10.3389/fmicb.2017.01280.

Cobbing, E.J., 1999, The Coastal Batholith and other aspects of Andean magmatism in Peru: Geological Society, London, Special Publications, v. 168, p. 111-122.

Colman, D.R., Garcia, J.R., Crossey, L.J., Karlstrom, K., Jackson-Weaver, O., and TakacsVesbach, C., 2014, An analysis of geothermal and carbonic springs in the western United States sustained by deep fluid inputs: Geobiology, v. 12, p. 83-98, doi: 10.1111/gbi.12070.

Colman, D.R., Feyhl-Buska, J., Robinson, K.J., Fecteau, K.M., Xu, H., Shock, E.L., and Boyd, E.S., 2016, Ecological differentiation in planktonic and sediment-associated chemotrophic microbial populations in Yellowstone hot springs: FEMS Microbiology Ecology, v. 92, doi: 10.1093/femsec/fiw137.

Colman, D.R., Poudel, S., Hamilton, T.L., Havig, J.R., Selensky, M.J., Shock, E.L., and Boyd, E.S., 2018, Geobiological feedbacks and the evolution of thermoacidophiles: ISME Journal, v. 12, p. 225-236, doi: 10.1038/ismej.2017.162.

Cox, A., Shock, E.L., and Havig, J.R., 2011, The transition to microbial photosynthesis in hot spring ecosystems: Chemical Geology, v. 280, p. 344-351, doi: 10.1016/j.chemgeo.2010.11.022.

de Hoog, J.C.M., Taylor, B.E., and van Bergen, M.J., 2001, Sulfur isotope systematics of basaltic lavas from Indonesia: implications for the sulfur cycle in subduction zones: Earth and Planetary Science Letters, v. 189, p. 237-252.

De La Cruz, N.B., 1995, Geologia de los cuadrangulos de Velille, Yauri, Ayaviri, y Azangaro: Instituto Geologico Minero y Metalurgico, v. Serie A, doi: 10.1017/CBO9781107415324.004.

Eby, G.N., 2016, Principles of Environmental Geochemistry: Long Grove, Illinois, Waveland Press.

Edgar, R.C., Haas, B.J., Clemente, J.C., Quince, C., and Knight, R., 2011, UCHIME improves sensitivity and speed of chimera detection: Bioinformatics, v. 27, p. 21942200, doi: 10.1093/bioinformatics/btr381. 
Fournier, R.O., 1989, Geochemistry and Dynamics of the Yellowstone National Park Hydrothermal System: Ann. Rev. Earth Planet. Sci., v. 17, p. 13-53.

Fournier, R.O., and Truesdell, A.H., 1973, An empirical NaKCa geothermometer for natural waters: Geochimica et Cosmochimica Acta, v. 37, p. 1255-1275, doi: 10.1016/0016-7037(73)90060-4.

Fullerton, K.M., Schrenk, M., Yucel, M., Manini, E., Fattorini, D., Carlo, M. di, Regoli, F., Nakagawa, M., Smedile, F., Vetriani, C., Miller, H., Morrison, S., Martinez, M., Moor, J.M. de, et al., 2019, Plate tectonics drive deep biosphere microbial community composition: EarthArXiv, doi: 10.31223/OSF.IO/GYR7N.

Gan, H.M., Chew, T.H., Tay, Y.-L., Lye, S.F., and Yahya, A., 2012, Genome Sequence of Hydrogenophaga sp. Strain PBC, a 4-Aminobenzenesulfonate-Degrading Bacterium: Journal of Bacteriology, v. 194, p. 4759-4760, doi: 10.1128/JB.00990-12.

Gan, H.M., Shahir, S., Ibrahim, Z., and Yahya, A., 2010, Biodegradation of 4aminobenzenesulfonate by Ralstonia sp. PBA and Hydrogenophaga sp. PBC isolated from textile wastewater treatment plant: Chemosphere, doi: 10.1016/j.chemosphere.2010.10.094.

Garcia-Dominguez, E., Mumford, A., Rhine, E.D., Paschal, A., and Young, L.Y., 2008, Novel autotrophic arsenite-oxidizing bacteria isolated from soil and sediments: FEMS Microbiology Ecology, v. 66, p. 401-410, doi: 10.1111/j.1574-6941.2008.00569.x.

Garrity, G.M., Holt, J.G., Hatchikian, E.C., Ollivier, B., and Garcia, J.-L., 2001, Phylum BIII. Thermodesulfobacteria phy. nov., in Bergey's Manual ${ }^{\circledR}$ of Systematic Bacteriology, Springer New York, p. 389-393, doi: 10.1007/978-0-387-21609-6_20.

Giggenbach, W.F., 1988, Geothermal solute equilibria. Derivation of Na-K-Mg-Ca geoindicators: Geochimica et Cosmochimica Acta, v. 52, p. 2749-2765, doi: 10.1016/0016-7037(88)90143-3.

Global Volcanism Program, 2013, Quimsachata (354000): Smithsoian Institution, v. 4.8.8.

Gold, T., 1992, The deep, hot biosphere: Proceedings of the National Academy of Sciences of the United States of America, v. 89, p. 6045-6049, doi: 10.1073/pnas.89.13.6045.

Gutscher, M.-A., Spakman, W., Bijwaard, H., and Engdahl, E.R., 2000, Geodynamics of flat subduction: Seismicity and tomographic constraints from the Andean margin: Tectonics, v. 19, p. 814-833, doi: 10.1029/1999TC001152.

HACH, 2015, Sulfide - Method 8131: Water Analysis Handbook, doi: DOC316.53.01136.

HACH, 2014, Iron, Ferrous - Method 8146: Water Analysis Handbook, doi: DOC316.53.01049. 
Hamilton, T.L., Peters, J.W., Skidmore, M.L., and Boyd, E.S., 2013, Molecular evidence for an active endogenous microbiome beneath glacial ice: International Society for Microbial Ecology Journal, v. 7, p. 1402-1412, doi: 10.1038/ismej.2013.31.

Hampel, A., 2002, The migration history of the Nazca Ridge along the Peruvian active margin: a re-evaluation: Earth and Planetary Science Letters, v. 203, p. 665-679.

Han, W.S., Lu, M., McPherson, B.J., Keating, E.H., Moore, J., Park, E., Watson, Z.T., and Jung, N.-H., 2013, Characteristics of $\mathrm{CO}_{2}$-driven cold-water geyser, Crystal Geyser in Utah: experimental observation and mechanism analyses: Geofluids, v. 13, p. 283297, doi: $10.1111 / \mathrm{gfl} .12018$.

Hayes, G., 2018, Slab2 - A Comprehensive Subduction Zone Geometry Model: U.S. Geological Survey data release, doi: 10.5066/F7PV6JNV.

Henry, S.G., and Pollack, H.N., 1988, Terrestrial heat flow above the Andean subduction zone in Bolivia and Peru: Journal of Geophysical Research, v. 93, p. 153-162, doi: 10.1029/jb093ib12p15153.

Hilton, D.R., Fischer, T.P., and Marty, B., 2002, Noble Gases and Volatile Recycling at Subduction Zones: Reviews in Mineralogy and Geochemistry, v. 47, p. 319-370, doi: 10.2138/rmg.2002.47.9.

Hilton, D.R., 1996, The helium and carbon isotope systematics of a continental geothermal system: Results from monitoring studies at Long Valley caldera (California, U.S.A.): Chemical Geology, v. 127, p. 269-295, doi: 10.1016/0009-2541(95)00134-4.

Hoke, L., and Lamb, S., 2007, Cenozoic behind-arc volcanism in the Bolivian Andes, South America: implications for mantle melt generation and lithospheric structure: Journal of the Geological Society, v. 164, p. 795-814, doi: 10.1144/0016-76492006092.

Horton, B.K., Perez, N.D., Fitch, J.D., and Saylor, J.E., 2014, Punctuated shortening and subsidence in the Altiplano Plateau of southern Peru: Implications for early Andean mountain building: Lithosphere, v. 7, p. 117-137.

Horton, B.K., 2018, Sedimentary record of Andean mountain building: Earth-Science Reviews, v. 178, p. 279-309, doi: 10.1016/j.earscirev.2017.11.025.

Huamaní Huaccán, A., 2001, Aguas termales y minerales en el suroriente del Peru (Dptos. Apurimac, Cusco, Madre de Dios y Puno): Instituto Geológico, Minero y Metalúrgico - INGEMMET, v. Serie D. 
Huang, Q., Dong, C.Z., Dong, R.M., Jiang, H., Wang, S., Wang, G., Fang, B., Ding, X., Niu, L., Li, X., Zhang, C., and Dong, H., 2011, Archaeal and bacterial diversity in hot springs on the Tibetan Plateau, China: Extremophiles, v. 15, p. 549-563, doi: 10.1007/s00792-011-0386-z.

Huber, H., and Stetter, K.O., 2001, Family I. Desulfurococcaceae, in Boone, D.R., Castenholz, R.W., and Garrity, G.M. eds., Bergey's Manual ${ }^{\circledR}$ of Systematic Bacteriology, Springer, p. 180-181.

Hudson, A.J., Morgan, H.W., and Daniel, R.M., 1986, A Numerical Classification of Some Thermus Isolates: Journal of General Microbiology, v. 132, p. 531-540.

Hurwitz, S., and Lowenstern, J.B., 2014, Dynamics of the Yellowstone hydrothermal system: Reviews of Geophysics, v. 51, p. 375-411, doi: 10.1002/2014RG000452.

Inskeep, W.P., Ackerman, G.G., Taylor, W.P., KozubalL, M., Korf, S., and Macur, R.E., 2005, On the energetics of chemolithotrophy in nonequilibrium systems: case studies of geothermal springs in Yellowstone National Park: Geobiology, v. 3, p. 297-317, doi: 10.1111/j.1472-4669.2006.00059.x.

Inskeep, W.P., Jay, Z.J., Macur, R.E., Clingenpeel, S., Tenney, A., Lovalvo, D., Beam, J.P., Kozubal, M.A., Shanks, W.C., Morgan, L.A., Kan, J., Gorby, Y., Yooseph, S., and Nealson, K., 2015, Geomicrobiology of sublacustrine thermal vents in Yellowstone Lake: Geochemical controls on microbial community structure and function: Frontiers in Microbiology, v. 6, doi: 10.3389/fmicb.2015.01044.

James, D.E., 1978, Subduction of the Nazca plate beneath central Peru: Geology, v. 6, p. $174-178$.

Jelen, B.I., Giovannelli, D., and Falkowski, P.G., 2016, The Role of Microbial Electron Transfer in the Coevolution of the Biosphere and Geosphere: The Annual Review of Microbiology, v. 70, p. 45-62, doi: 10.1146/annurev-micro-102215-095521.

Keating, E.H., Fessenden, J., Kanjorski, N., Koning, D.J., and Pawar, R., 2010, The impact of $\mathrm{CO}_{2}$ on shallow groundwater chemistry: observations at a natural analog site and implications for carbon sequestration: Environmental Earth Science, v. 60, p. 521536, doi: 10.1007/s12665-009-0192-4.

Kieft, T.L., McCuddy, S.M., Onstott, T.C., Davidson, M., Lin, L.-H., Mislowack, B., Pratt, L., Boice, E., Lollar, B.S., Lippmann-Pipke, J., Pfiffner, S.M., Phelps, T.J., Gihring, T., Moser, D., et al., 2005, Geochemically Generated, Energy-Rich Substrates and Indigenous Microorganisms in Deep, Ancient Groundwater: Geomicrobiology Journal, v. 22, p. 325-335, doi: 10.1080/01490450500184876. 
Kuever, J., Rainey, F.A., and Widdel, F., 2005, Class IV. Deltaproteobacteria class nov., in Brenner, D.J., Krieg, N.R., Staley, J.T., and Garrity, G.M. eds., Bergey's Manual ${ }^{\circledR}$ of Systematic Bacteriology, Springer, p. 922.

Lamb, S., and Hoke, L., 1997, Origin of the high plateau in the central Andes, Bolivia, South America: Tectonics, v. 16, p. 623-649, doi: 10.1029/97TC00495.

Lin, S., Hameed, A., Wen, C., Hsu, Y., Liu, Y., Lai, W., and Young, C., 2017, Hydrogenophaga aquatica sp . nov ., isolated from a hot spring: International Journal of Systematic and Evolutionary Microbiology, v. 67, p. 3716-3721, doi: 10.1099/ijsem.0.002146.

Lindsay, M.R., Amenabar, M.J., Fecteau, K.M., Debes, R. V., Fernandes Martins, M.C., Fristad, K.E., Xu, H., Hoehler, T.M., Shock, E.L., and Boyd, E.S., 2018, Subsurface processes influence oxidant availability and chemoautotrophic hydrogen metabolism in Yellowstone hot springs: Geobiology, v. 0, p. 1-19, doi: 10.1111/gbi.12308.

Lloyd, J.R., and Oremland, R.S., 2006, Microbial Transformations of Arsenic in the Environment: From Soda Lakes to Aquifers: Elements, v. 2, p. 85-90, doi: 10.2113/gselements.2.2.85.

Lovley, D.R., and Chapelle, F.H., 1995, Deep subsurface microbial processes: Reviews of Geophysics, v. 33, p. 365-381, doi: 10.1029/95RG01305.

Macur, R.E., Langer, H.W., Kocar, B.D., and Inskeep, W.P., 2004, Linking geochemical processes with microbial community analysis: successional dynamics in an arsenicrich, acid-sulphate-chloride geothermal spring: Geobiology, v. 2, p. 163-177, doi: 10.1111/j.1472-4677.2004.00032.x.

Madigan, M.T., Bender, K.S., Buckley, D.H., Stahl, D.A., and Sattley, W.M., 2017, Brock Biology of Microorganisms: Pearson Education, ISBN: 0134626109.

Makita, H., Tanaka, E., Mitsunobu, S., Miyazaki, M., Nunoura, T., Uematsu, K., Takaki, Y., Nishi, S., Shimamura, S., and Takai, K., 2017, Mariprofundus micogutta sp. nov., a novel iron-oxidizing zetaproteobacterium isolated from a deep-sea hydrothermal field at the Bayonnaise knoll of the Izu-Ogasawara arc, and a description of Mariprofundales ord. nov. and Zetaproteobacteria classis nov.: Archives of Microbiology, v. 199, p. 335-346, doi: 10.1007/s00203-016-1307-4.

Mamani, M., Wörner, G., and Sempere, T., 2010, Geochemical variations in igneous rocks of the Central Andean orocline ( $13^{\circ} \mathrm{S}$ to $\left.18^{\circ} \mathrm{S}\right)$ : Tracing crustal thickening and magma generation through time and space: GSA Bulletin, v. 122, p. 162-182, doi: 10.1130/B26538.1. 
Manea, V.C., Manea, M., Ferrari, L., Orozco, T., Valenzuela, R.W., Husker, A., and Kostoglodov, V., 2017, A review of the geodynamic evolution of flat slab subduction in Mexico, Peru, and Chile: Tectonophysics, v. 695, p. 27-52, doi: 10.1016/j.tecto.2016.11.037.

Mckee, E.H., and Noble, D.C., 1982, Miocene volcanism and deformation in the western Cordillera and high plateaus of south-central Peru: Geological Society of America Bulletin, v. 93, p. 657-662.

Megard, F., 1984, The Andean orogenic period and its major structures in central and northern Peru: Journal of the Geological Society, v. 141, p. 893-900, doi: 10.1144/gsjgs.141.5.0893.

Merino, N., Aronson, H.S., Bojanova, D.P., Feyhl-Buska, J., Wong, M.L., Zhang, S., and Giovannelli, D., 2019, Living at the extremes: Extremophiles and the limits of life in a planetary context: Frontiers in Microbiology, v. 10, doi: 10.3389/fmicb.2019.00780.

Miroshnichenko, M.L., Lebedinsky, A. V, Chernyh, N.A., Tourova, T.P., Kolganova, T. V, Spring, S., and Bonch-osmolovskaya, E.A., 2009, Caldimicrobium rimae gen. nov., sp. nov., an extremely thermophilic, facultatively lithoautotrophic, anaerobic bacterium from the Uzon Caldera, Kamchatka: International Journal of Systematic and Evolutionary Microbiology, v. 59, p. 1040-1044, doi: 10.1099/ijs.0.006072-0.

Mitchell, K.R., and Takacs-Vesbach, C.D., 2008, A comparison of methods for total community DNA preservation and extraction from various thermal environments: Journal of Industrial Microbiology \& Biotechnology, v. 35, p. 1139-1147, doi: 10.1007/s10295-008-0393-y.

Moser, D.P., Gihring, T.M., Brockman, F.J., Fredrickson, J.K., Balkwill, D.L., Dollhopf, M.E., Sherwood Lollar, B., Pratt, L.M., Boice, E., Southam, G., Wanger, G., Baker, B.J., Pfiffner, S.M., Lin, L.-H., et al., 2005, Desulfotomaculum and Methanobacterium spp. Dominate a 4-to 5-Kilometer-Deep Fault: Applied and Environmental Microbiology, v. 71, p. 8773-8783, doi: 10.1128/AEM.71.12.87738783.2005.

Newell, D.L., Jessup, M.J., Cottle, J.M., Hilton, D.R., Sharp, Z.D., and Fischer, T.P., 2008, Aqueous and isotope geochemistry of mineral springs along the southern margin of the Tibetan plateau: Implications for fluid sources and regional degassing of $\mathrm{CO}_{2}$ : Geochemistry, Geophysics, Geosystems, v. 9, doi: 10.1029/2008GC002021.

Newell, D.L., Jessup, M.J., Hilton, D.R., Shaw, C.A., and Hughes, C.A., 2015, Mantlederived helium in hot springs of the Cordillera Blanca, Peru: Implications for mantleto-crust fluid transfer in a flat-slab subduction setting: Chemical Geology, v. 417, p. 200-209, doi: 10.1016/J.CHEMGEO.2015.10.003.

Oksanen, J., 2015, Multivariate Analysis of Ecological Communities in R: vegan tutorial. 
Oksanen, J., Blanchet, F.G., Friendly, M., Kindt, R., Legendre, P., Mcglinn, D., Minchin, P.R., O’hara, R.B., Simpson, G.L., Solymos, P., Henry, M., Stevens, H., Szoecs, E., and Maintainer, H.W., 2019, Package "vegan" Community Ecology Package.

Oremland, R.S., Stolz, J.F., and Hollibaugh, J.T., 2004, The microbial arsenic cycle in Mono Lake, California: FEMS Microbiology Ecology, v. 48, p. 15-27, doi: 10.1016/j.femsec.2003.12.016.

Pajuelo, D., Rowe, M.C., Campbell, K.A., and El Sol, A., 2020, High Altitude, IronCarbonate, Subaqueous Hot-Spring Precipitates of the Central Andes, Peru, in Proceedings World Geothermal Congress, Reykjavik, Iceland.

Parkhurst, D.L., and Appelo, C.A.J., 2013, Description of input and examples for PHREEQC version 3-A computer program for speciation, batch-reaction, onedimensional transport, and inverse geochemical calculations:, https://pubs.usgs.gov/tm/06/a43/.

Perelló, J., Carlotto, V., Zárate, A., Ramos, P., Posso, H., Neyra, C., Caballero, A., Fuster, N., and Muhr, R., 2003, Porphyry-style alteration and mineralization of the Middle Eocene to Early Oligocene Andahuaylas-Yauri Belt, Cuzco Region, Peru: Economic Geology, v. 98, p. 1575-1605, doi: 10.2113/gsecongeo.98.8.1575.

Piper, A.M., 1944, A Graphic Procedure in the Geochemical Interpretation of WaterAnalysis: Hydrology, p. 914-928, doi: 10.1029/tr049i004p00626.

Plümper, O., King, H.E., Geisler, T., Liu, Y., Pabst, S., Savov, I.P., Rost, D., and Zack, T., 2017, Subduction zone forearc serpentinites as incubators for deep microbial life: Proceedings of the National Academy of Sciences of the United States of America, v. 114, p. 4324-4329, doi: 10.1073/pnas.1612147114.

Powell, T., and Cumming, W., 2010, Spreadsheets for geothermal water and gas chromatography, in Thirty-Fifth Workshop on Geothermal Reservoir Engineering.

Ramos, V.A., and Folguera, A.S., 2009, Andean flat-slab subduction through time: Ancient Orogens and Modern Analogues, Geological Society, London, Special Publications, v. 327, p. 31-54, doi: 10.1144/SP327.3.

Rempfert, K.R., Miller, H.M., Bompard, N., Nothaft, D., Matter, J.M., Kelemen, P., Fierer, N., and Templeton, A.S., 2017, Geological and geochemical controls on subsurface microbial life in the Samail Ophiolite, Oman: Frontiers in Microbiology, v. 8.

Reveillaud, J., Reddington, E., McDermott, J., Algar, C., Meyer, J.L., Sylva, S., Seewald, J., German, C.R., and Huber, J.A., 2016, Subseafloor microbial communities in hydrogen-rich vent fluids from hydrothermal systems along the Mid-Cayman Rise: Environmental microbiology, v. 18, p. 1970-1987, doi: 10.1111/1462-2920.13173. 
Sander, R., 2015, Compilation of Henry's law constants (version 4.0) for water as solvent: Atmos. Chem. Phys, v. 15, p. 4399-4981, doi: 10.5194/acp-15-4399-2015.

Sandeman, H.A., Clark, A.H., and Farrar, E., 1995, An Integrated Tectono-Magmatic Model for the Evolution of the Southern Peruvian Andes (13-20 $\mathrm{S})$ since $55 \mathrm{Ma}$ : International Geology Review, v. 37, p. 1039-1073, doi: 10.1080/00206819509465439.

Sano, Y., Kameda, A., Takahata, N., Yamamoto, J., and Nakajima, J., 2009, Tracing extinct spreading center in SW Japan by helium-3 emanation: Chemical Geology, v. 266, p. 50-56, doi: 10.1016/j.chemgeo.2008.10.020.

Scherrenberg, A.F., Kohn, B.P., Holcombe, R.J., and Rosenbaum, G., 2016, Thermotectonic history of the Marañón Fold-Thrust Belt, Peru: Insights into mineralisation in an evolving orogen: Tectonophysics, v. 667, p. 16-36.

Schloss, P.D., Westcott, S.L., Ryabin, T., Hall, J.R., Hartmann, M., Hollister, E.B., Lesniewski, R.A., Oakley, B.B., Parks, D.H., Robinson, C.J., Sahl, J.W., Stres, B., Thallinger, G.G., Van Horn, D.J., et al., 2009, Introducing mothur: Open-Source, Platform-Independent, Community-Supported Software for Describing and Comparing Microbial Communities: Applied and Environmental Microbiology, v. 75, p. 7537-7541, doi: 10.1128/AEM.01541-09.

Scire, A., Zandt, G., Beck, S., Long, M., Wagner, L., Minaya, E., and Tavera, H., 2016, Imaging the transition from flat to normal subduction: variations in the structure of the Nazca slab and upper mantle under southern Peru and northwestern Bolivia: Geophysical Journal International Geophys. J. Int, v. 204, p. 457-479, doi: $10.1093 /$ gji/ggv452.

Scott, B.E., Newell, D.L., Jessup, M.J., Grambling, T.A., and Shaw, C.A., 2020, Structural Controls on Crustal Fluid Circulation and Hot Spring Geochemistry Above a Flat-Slab Subduction Zone, Peru: Geochemistry, Geophysics, Geosystems, v. 21, doi: 10.1029/2020GC008919.

Shock, E.L., Holland, M., Meyer-Dombard, D., Amend, J.P., Osburn, G.R., and Fischer, T.P., 2010, Quantifying inorganic sources of geochemical energy in hydrothermal ecosystems, Yellowstone National Park, USA: Geochimica et Cosmochimica Acta, v. 74, p. 4005-4043, doi: 10.1016/J.GCA.2009.08.036.

Steinmüller, K., and Huamaní Huaccán, A., 1999, Aguas termales y minerales en el centro del Perú: INGEMMET. Bulletin, Series D: Regional Studies, v. Serie D.

Suarez, G., Molnar, P., and Burchfiel, B.C., 1983, Seismicity, fault plane solutions, depth of faulting, and active tectonics of the Andes of Peru, Ecuador and southern Colombia: Journal of geophysical research, v. 88, p. 10,403-10,428. 
USGS, 2006, National field manual for the collection of water-quality data: http://pubs.water.usgs.gov/twri9A.

Van Soest, M.C., Hilton, D.R., and Kreulen, R., 1998, Tracing crustal and slab contributions to arc magmatism in the Lesser Antilles island arc using helium and carbon relationships in geothermal fluids: Geochimica et Cosmochimica Acta, v. 62, p. 3323-3335, doi: 10.1016/S0016-7037(98)00241-5.

Wang, S., Dong, H., Hou, W., Jiang, H., Huang, Q., Briggs, B.R., and Huang, L., 2014, Greater temporal changes of sediment microbial community than its waterborne counterpart in Tengchong hot springs, Yunnan Province, China: Nature Scientific Reports, v. 4, doi: 10.1038/srep07479.

Wang, Y., Wang, Z., Liu, J., Chen, Y., Zhang, X., Wen, M., Xu, L., Peng, Q., and Cui, X., 2009, member of the Roseobacter clade in the order Rhodobacterales: International Journal of Systematic and Evolutionary Microbiology, v. 59, p. 1561-1567, doi: 10.1099/ijs.0.006965-0.

Ward, L., Taylor, M.W., Power, J.F., Scott, B.J., McDonald, I.R., and Stott, M.B., 2017, Microbial community dynamics in Inferno Crater Lake, a thermally fluctuating geothermal spring: ISME Journal, v. 11, p. 1158-1167, doi: 10.1038/ismej.2016.193.

Willems, A., and Gillis, M., 2005, Family IV. Comamondaceae, in Brenner, D.J., Krieg, N.R., Staley, J.T., and Garrity, G.M. eds., Bergey’s Manual ${ }^{\circledR}$ of Systematic Bacteriology, Springer, p. 686-688.

Zimmer, M.M., Fischer, T.P., Hilton, D.R., Alvarado, G.E., Sharp, Z.D., and Walker, J.A., 2004, Nitrogen systematics and gas fluxes of subduction zones: Insights from Costa Rica arc volatiles: Geochemistry, Geophysics, Geosystems, v. 5, doi: 10.1029/2003GC000651. 


\section{APPENDICES}


Appendix A. Representative spring photo compilation 

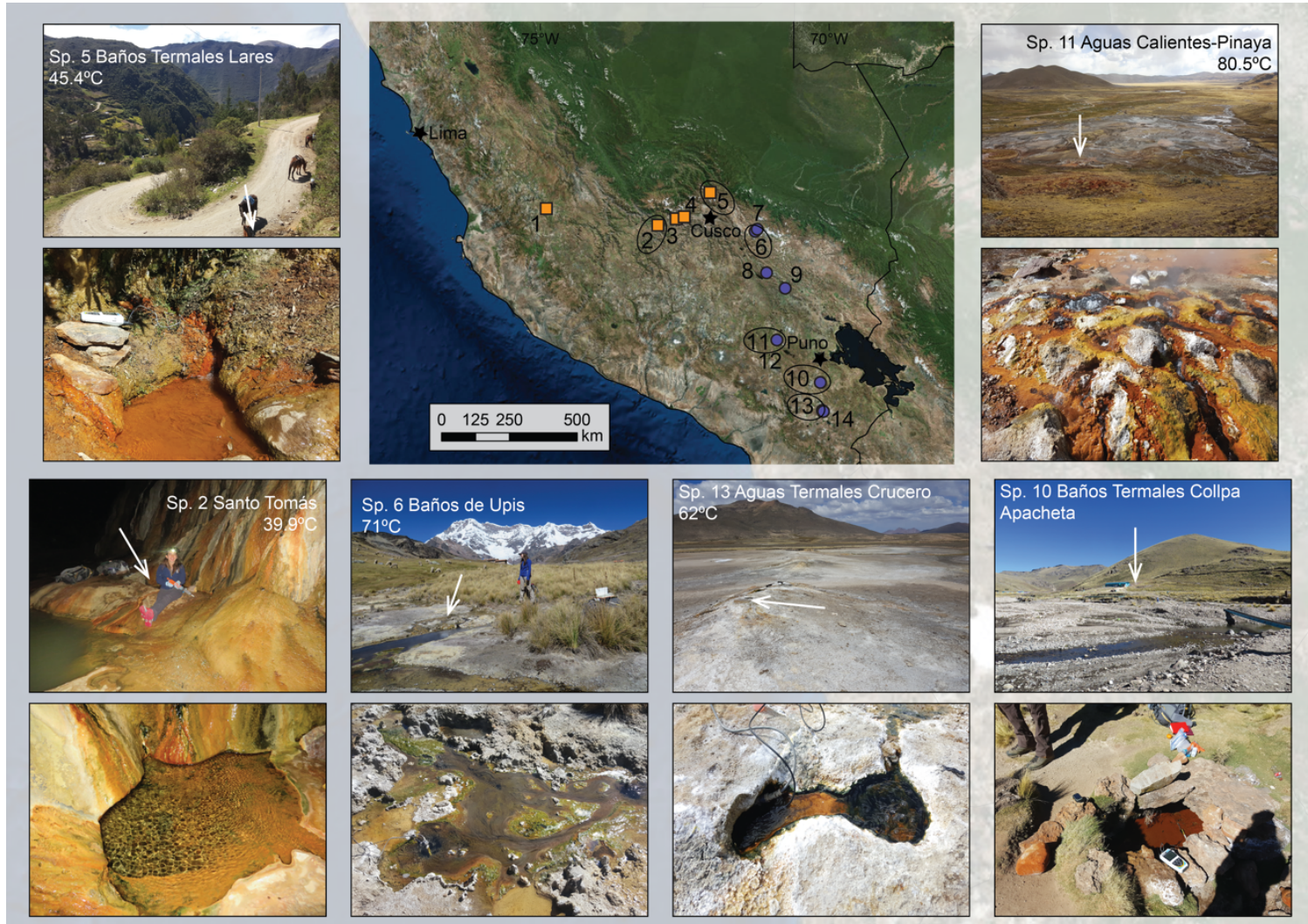

Figure A1. Representative thermal spring photos from the flat slab (Sp. 2, 5) and the backarc (Sp. 6, 10, 11, 13). These springs have a wide range of temperatures and compositions. They exhibit common features of the 14 springs, such as iron oxide and travertine deposits. Temperature and spring name are shown, and arrows denote the spring location. 
Appendix B. Aqueous and gas geochemistry and geothermometry data tables 


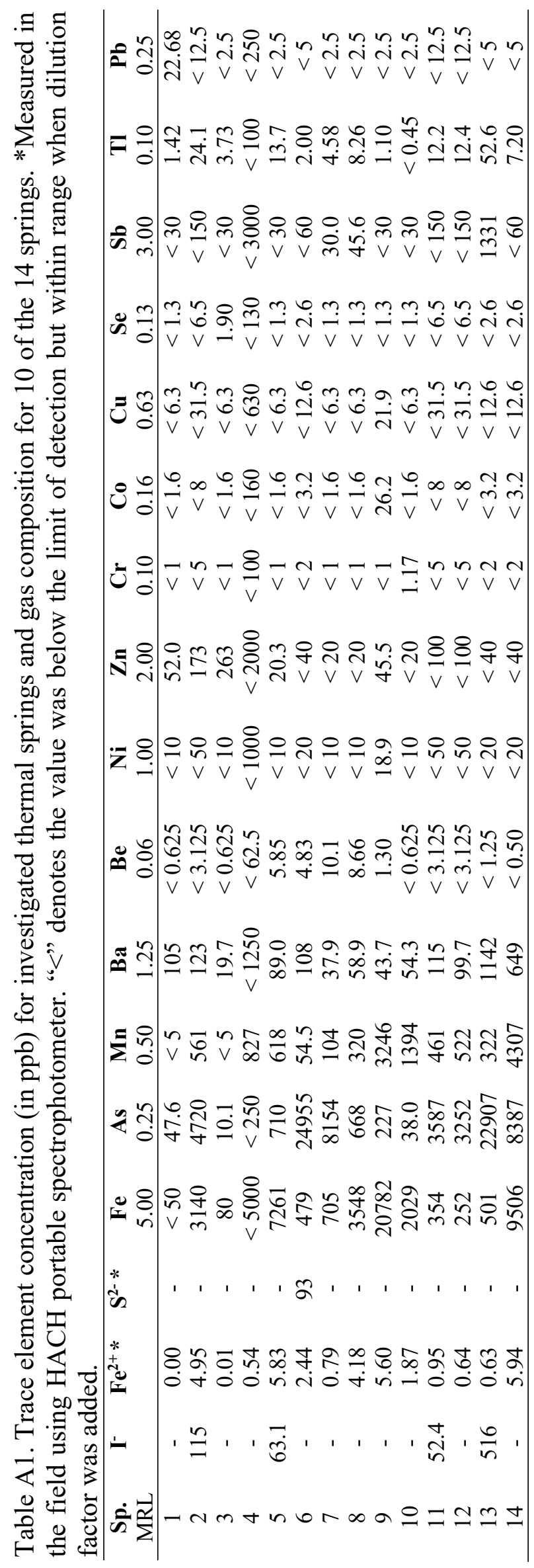

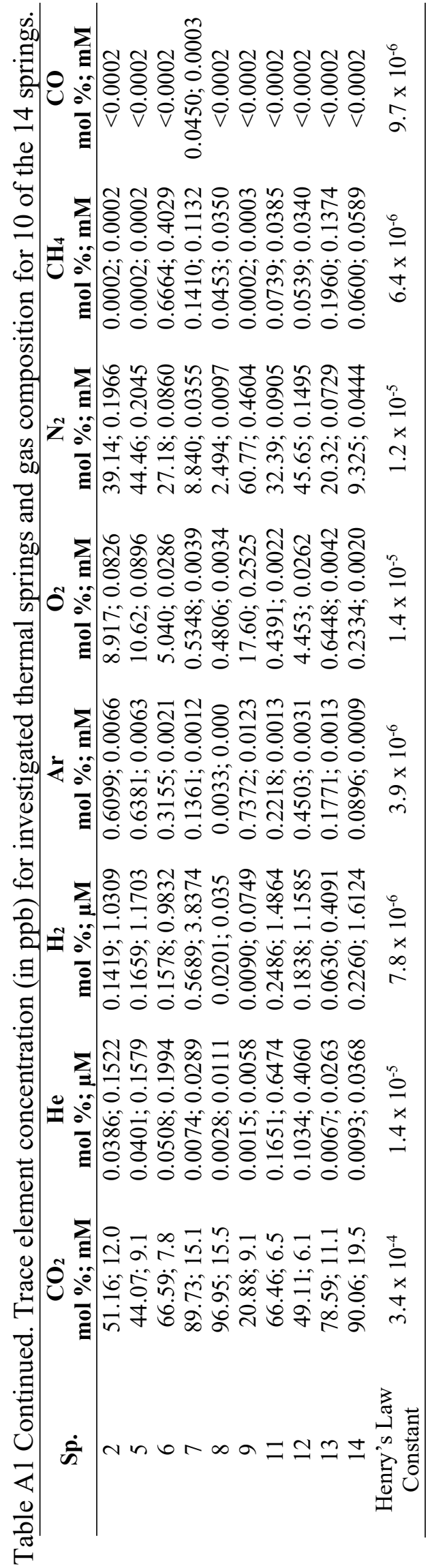


Table A2. Reservoir temperature estimates $\left({ }^{\circ} \mathrm{C}\right)$ from cation geothermometers. Sp. 4 was excluded from the analysis due to exceptionally high cation values that precluded the model constraints. The geothermometers with an * are used in this study.

\begin{tabular}{ccccccccc}
\hline Sp. & $\begin{array}{c}\text { Na-K- } \\
\text { Ca* }\end{array}$ & $\begin{array}{c}\mathbf{N a} / \mathbf{K} \\
\text { Fournier } \\
\mathbf{1 9 7 9}\end{array}$ & $\begin{array}{c}\mathbf{N a} / \mathbf{K} \\
\text { Truesdell } \\
\mathbf{1 9 7 6}\end{array}$ & $\begin{array}{c}\mathbf{N a} / \mathbf{K} \\
\text { Giggenbach } \\
\mathbf{1 9 8 8 *}\end{array}$ & $\begin{array}{c}\mathbf{N a} / \mathbf{K} \\
\text { Tonani } \\
\mathbf{1 9 8 0}\end{array}$ & $\begin{array}{c}\mathbf{N a} / \mathbf{K} \\
\mathbf{N i e v a} \& \\
\text { Nieva } \\
\mathbf{1 9 8 7}\end{array}$ & $\begin{array}{c}\mathbf{N a} / \mathbf{K} \\
\text { Arnorsson } \\
\mathbf{1 9 8 3}\end{array}$ & $\begin{array}{c}\text { K/Mg } \\
\text { Giggenbach } \\
\mathbf{1 9 8 6}^{*}\end{array}$ \\
\hline 1 & 40 & 230 & 205 & 245 & 242 & 217 & 211 & 53 \\
2 & 193 & 257 & 239 & 269 & 281 & 243 & 244 & 128 \\
3 & 56 & 124 & 77 & 144 & 100 & 113 & 89 & 44 \\
4 & - & - & - & - & - & - & - & - \\
5 & 131 & 227 & 200 & 242 & 237 & 214 & 207 & 92 \\
6 & 218 & 270 & 257 & 282 & 302 & 256 & 260 & 147 \\
7 & 117 & 239 & 216 & 253 & 255 & 225 & 222 & 101 \\
8 & 157 & 215 & 185 & 231 & 221 & 202 & 193 & 114 \\
9 & 127 & 177 & 138 & 195 & 168 & 165 & 148 & 85 \\
10 & 118 & 168 & 128 & 186 & 156 & 156 & 138 & 86 \\
11 & 175 & 170 & 131 & 188 & 159 & 158 & 141 & 130 \\
12 & 175 & 171 & 131 & 189 & 160 & 158 & 141 & 129 \\
13 & 214 & 202 & 169 & 218 & 202 & 189 & 177 & 159 \\
14 & 213 & 226 & 199 & 240 & 235 & 212 & 206 & 151 \\
\hline
\end{tabular}


Appendix C. Taxonomic information for $\geq 1 \%$ abundant OTUs 


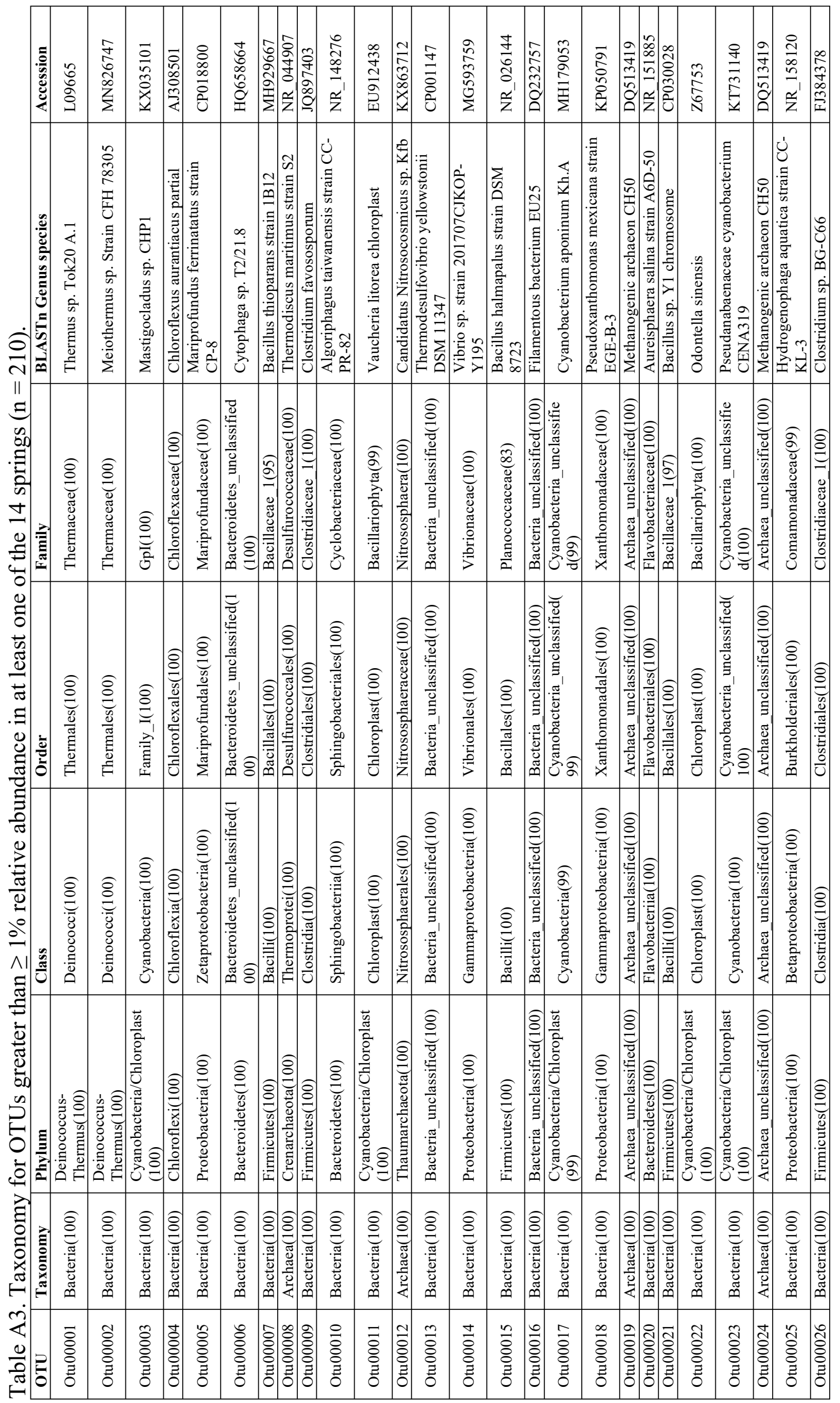




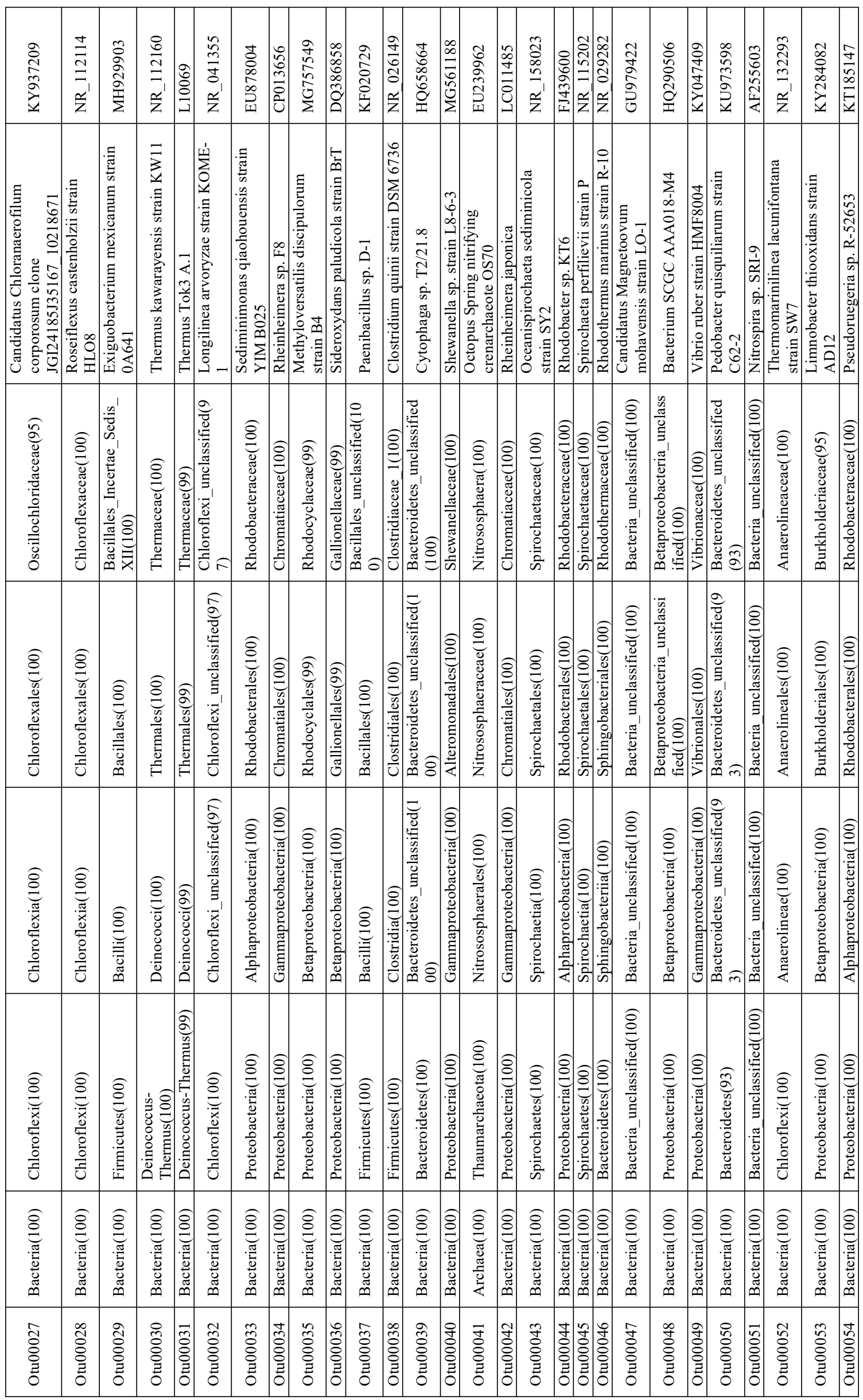




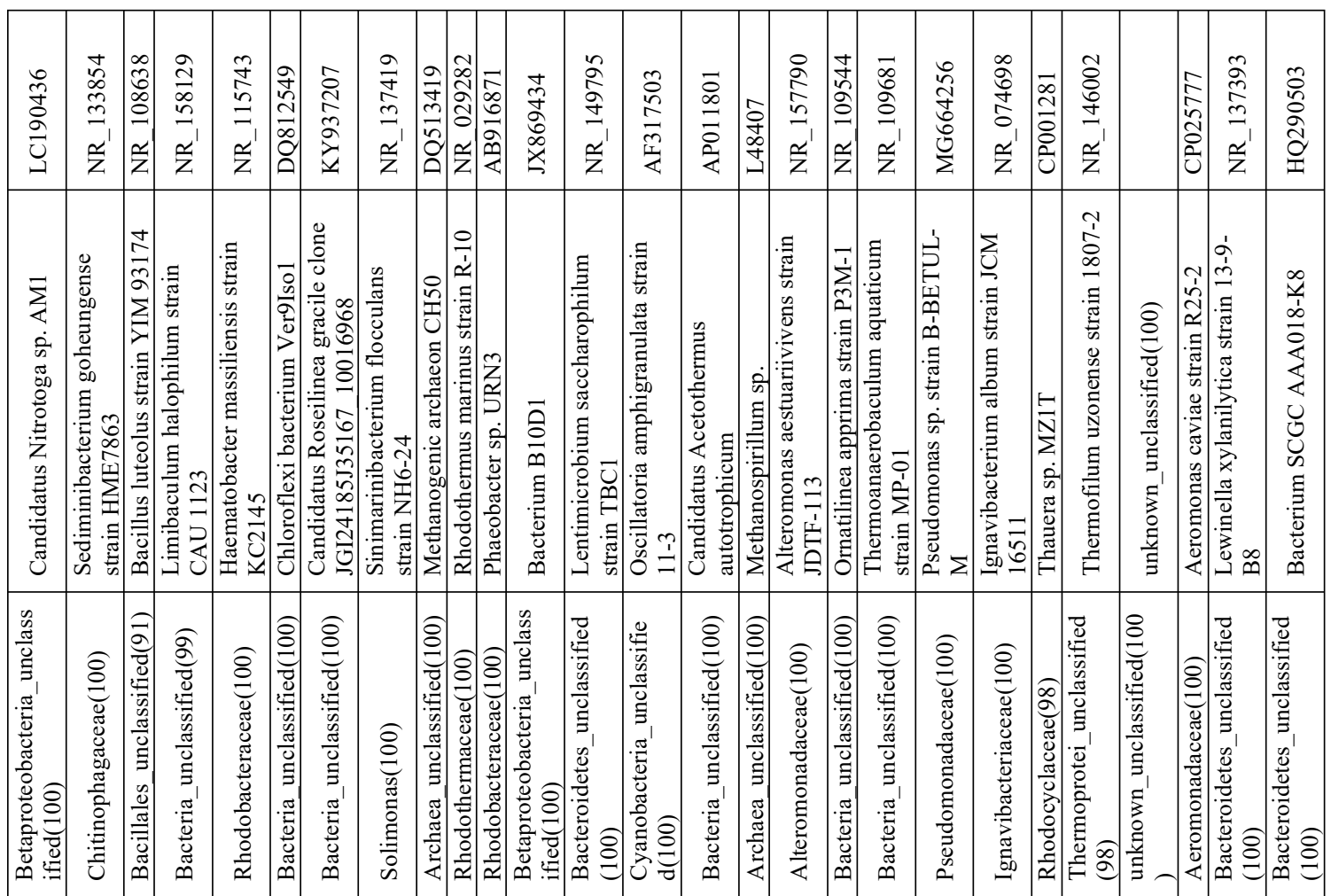

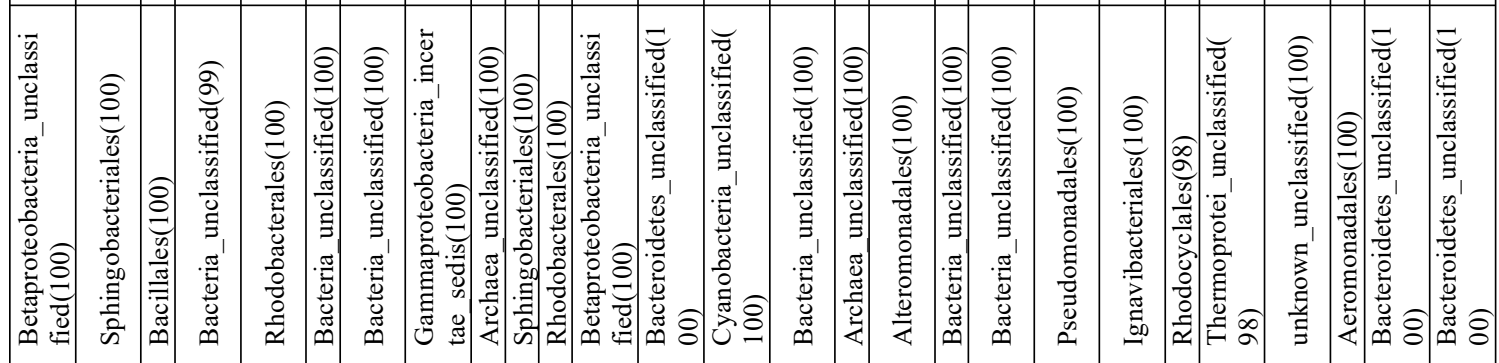

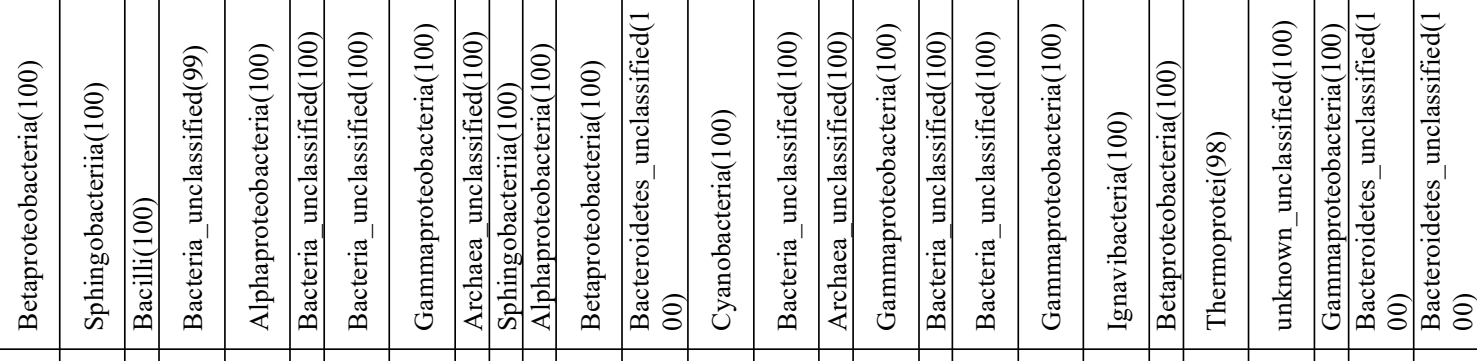

\begin{tabular}{|c|c|c|c|c|c|c|c|c|c|c|c|c|c|c|c|c|c|c|c|c|}
\hline & 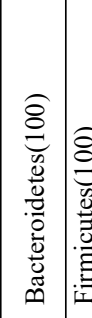 & 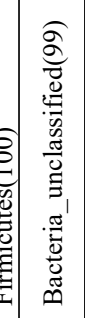 & 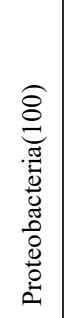 & 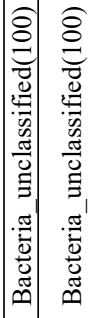 & 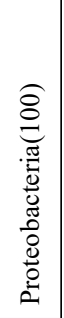 & 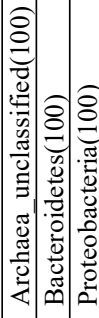 & 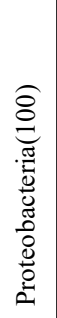 & 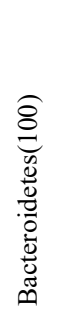 & 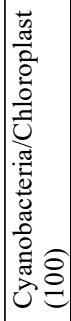 & 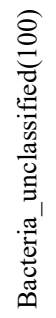 & 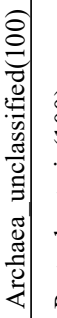 & 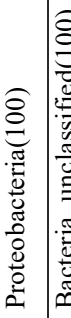 & 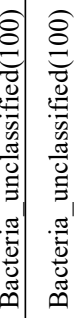 & 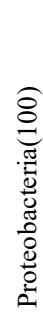 & & & 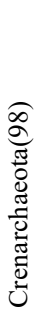 & 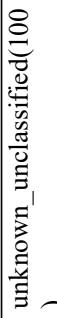 & 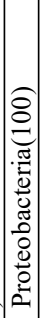 & 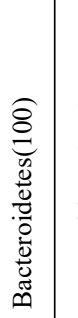 \\
\hline
\end{tabular}

ฉ

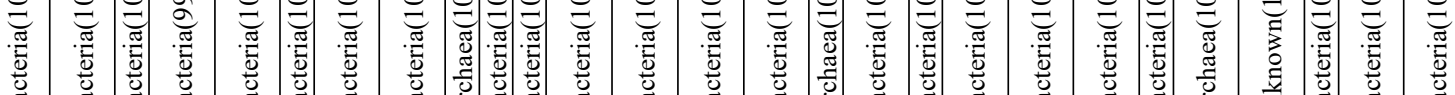

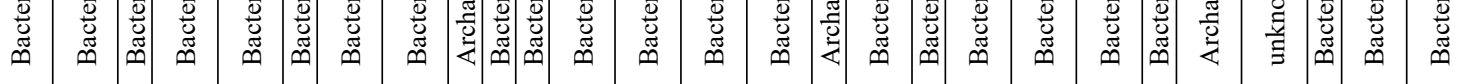

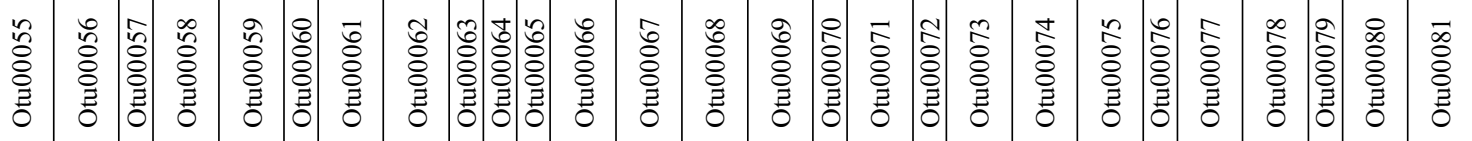




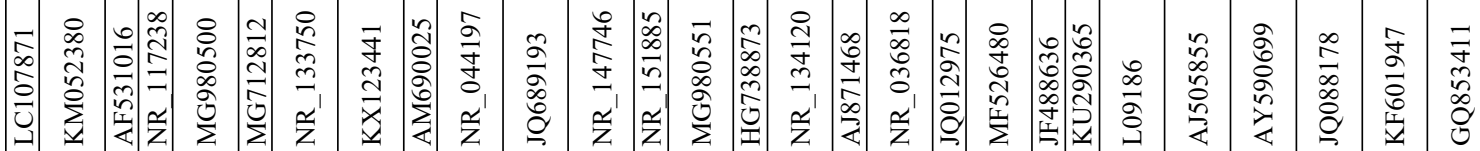

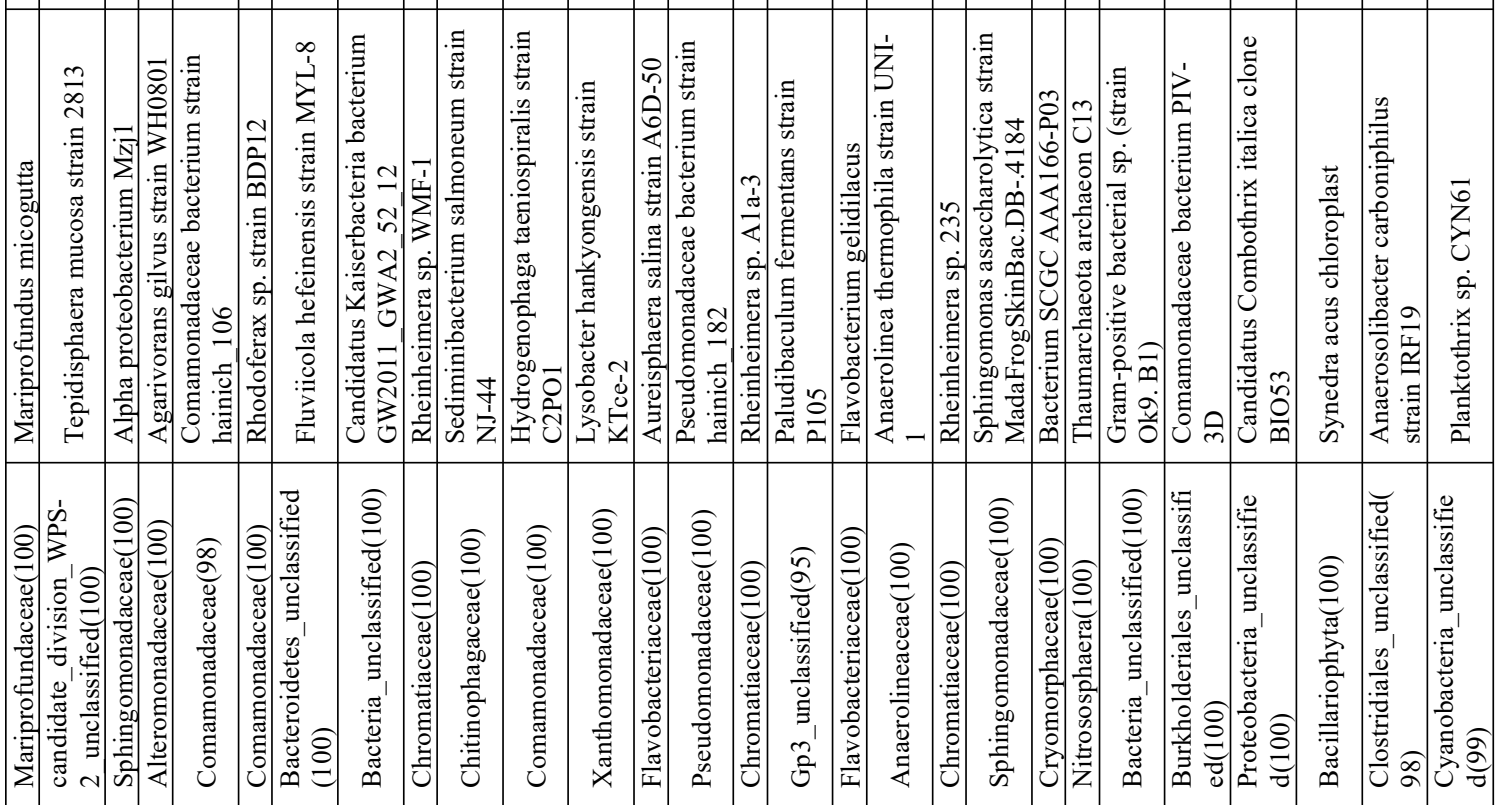

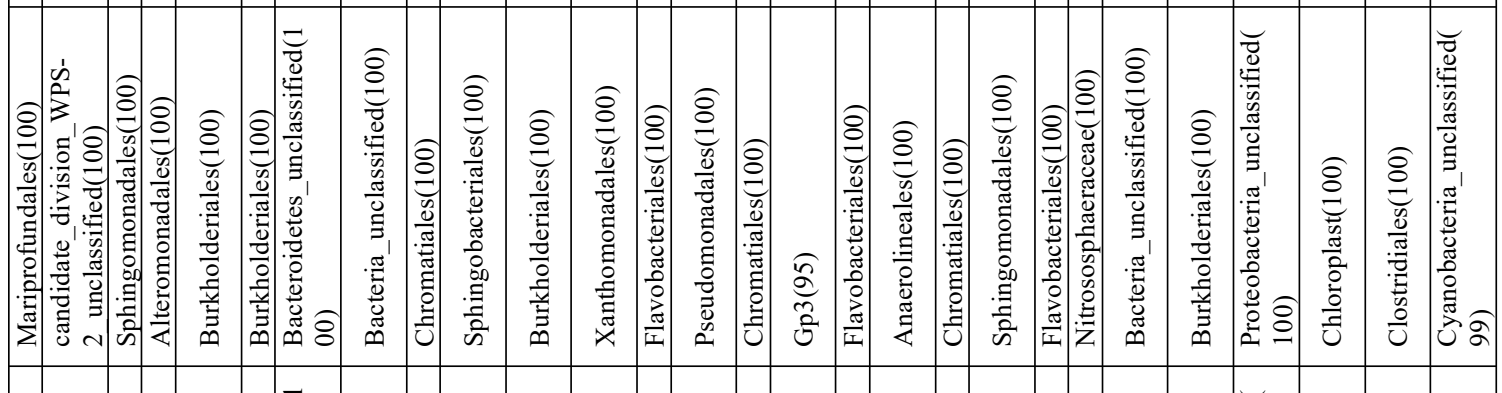

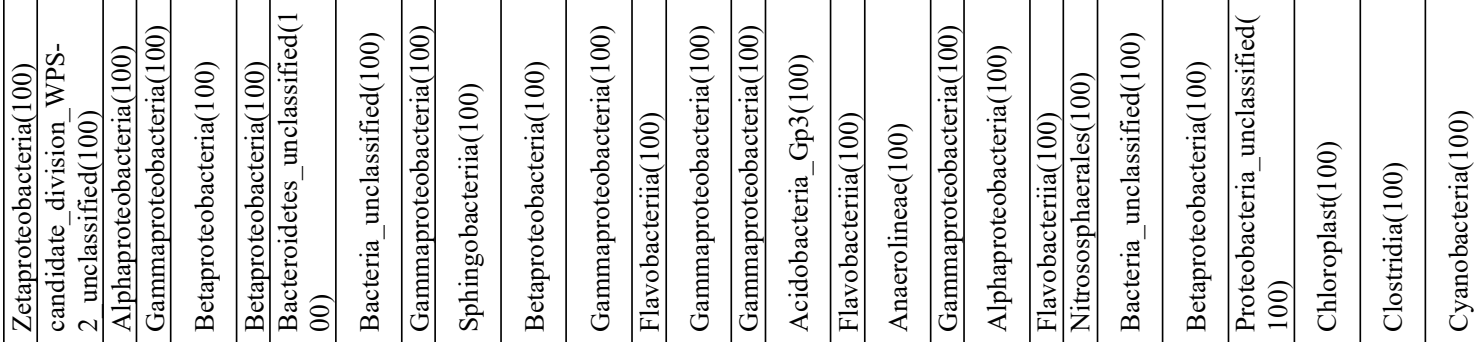

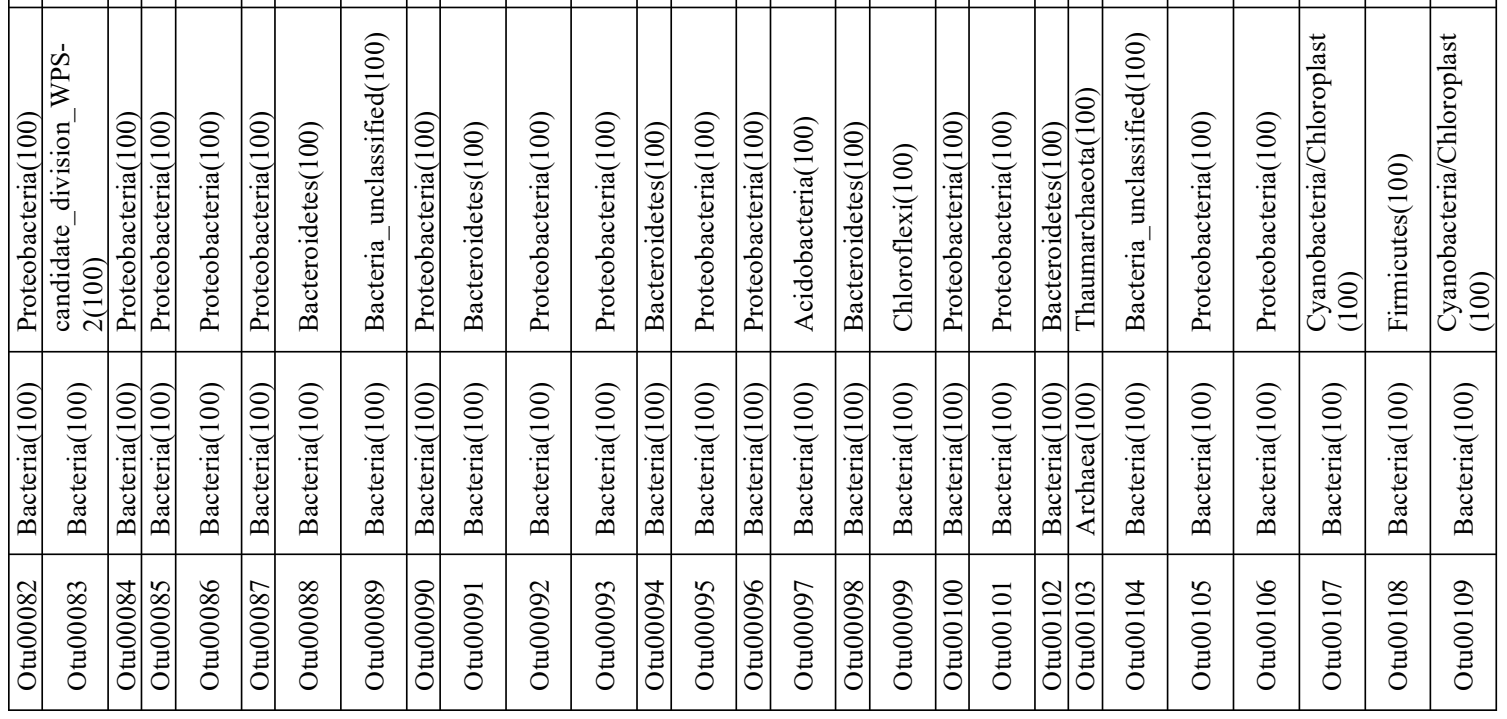




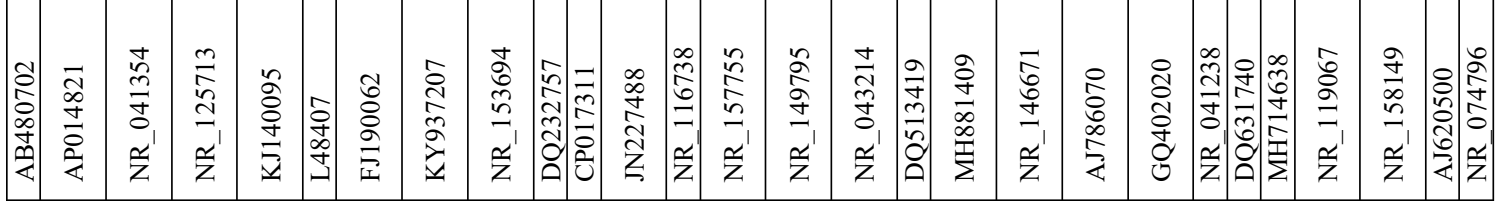

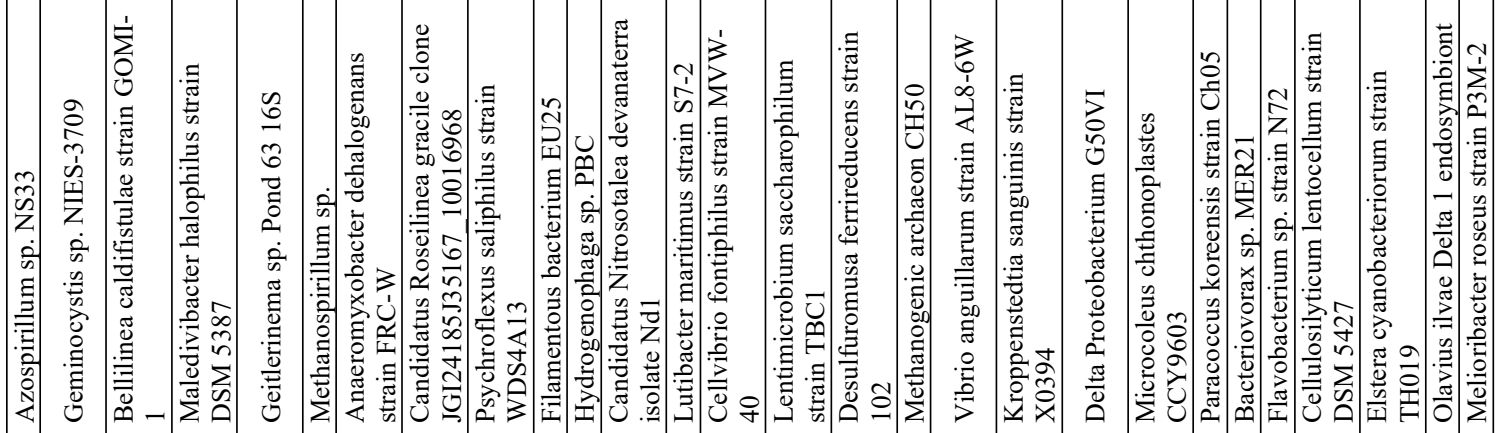

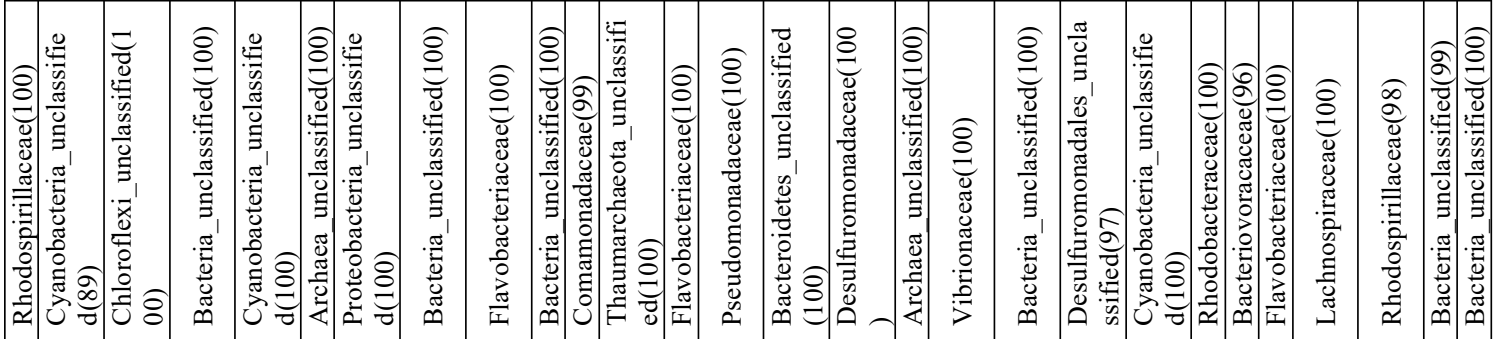

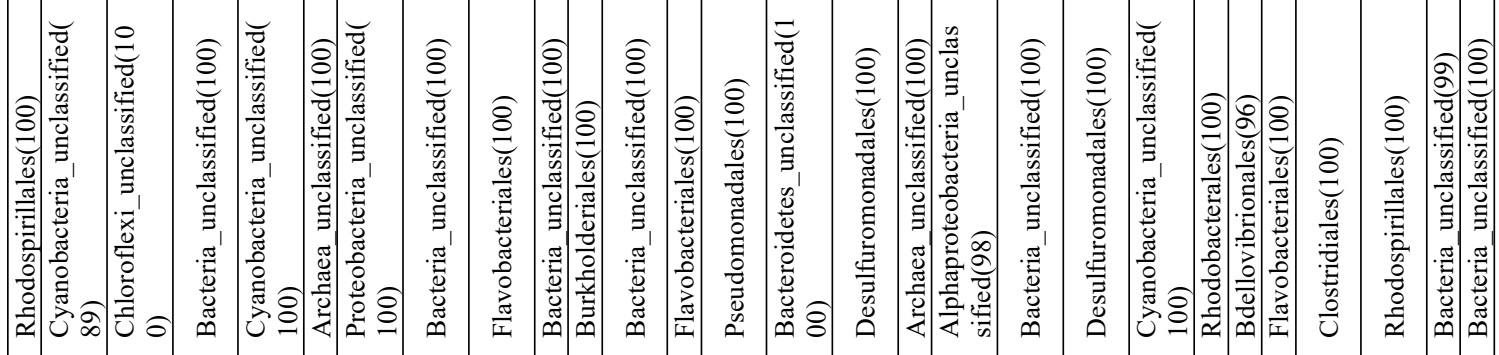

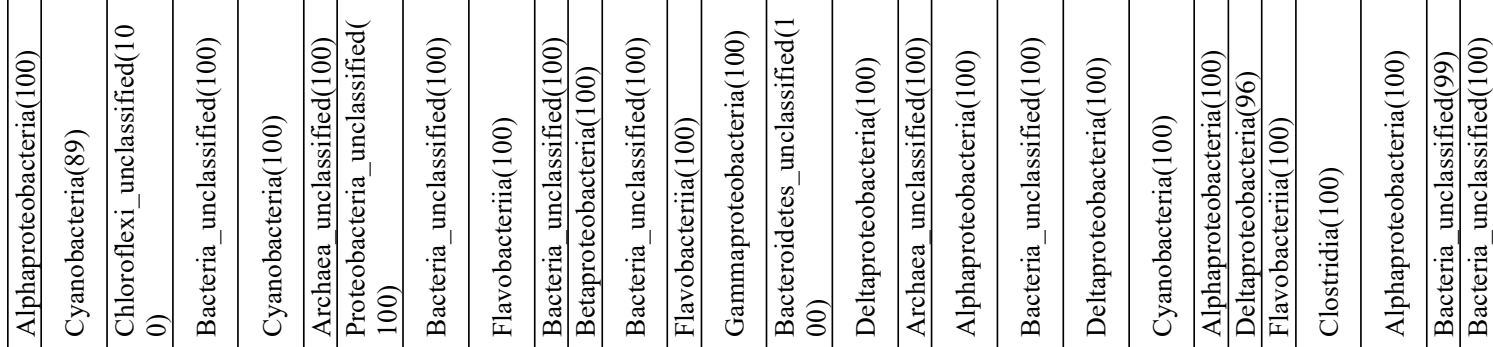

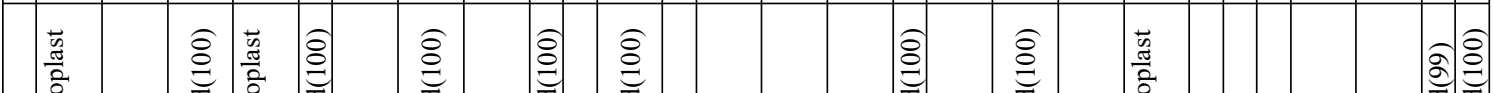

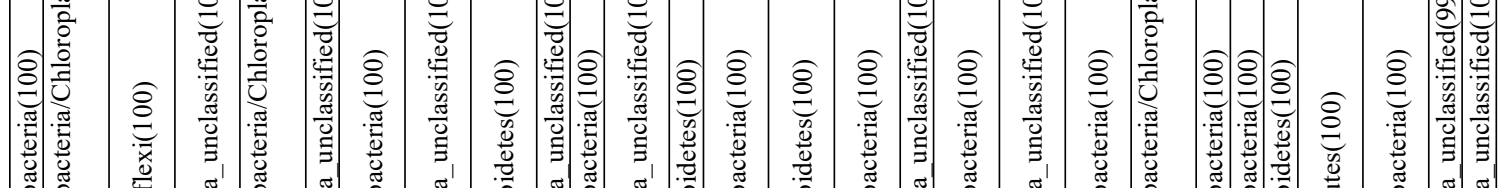

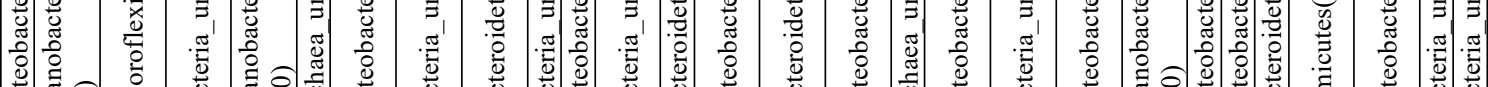

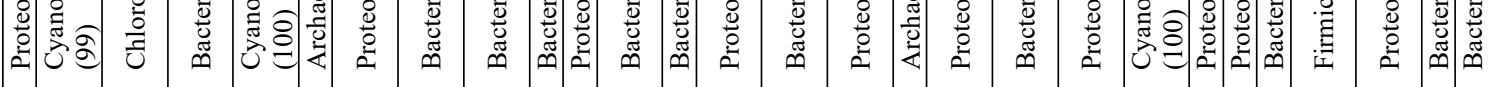

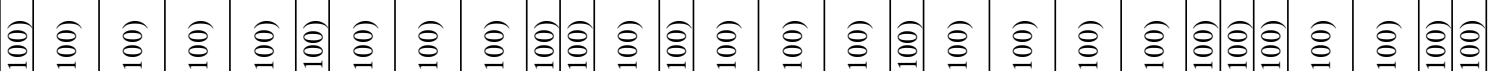

氙离

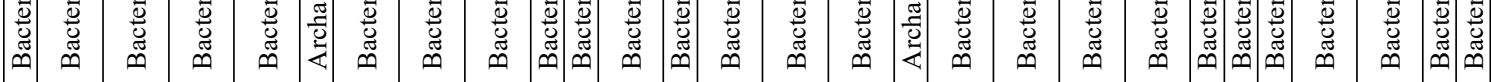

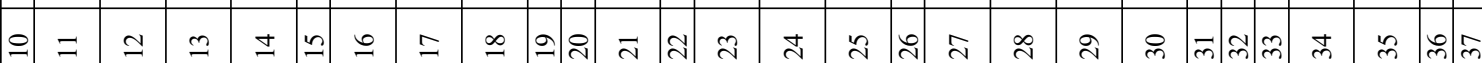

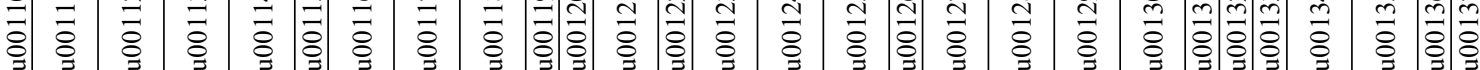

壳 


\begin{tabular}{|c|c|c|c|c|c|c|c|c|c|c|c|c|c|c|c|c|c|c|c|c|c|c|c|}
\hline 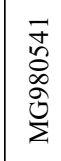 & 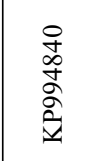 & 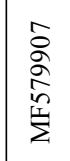 & 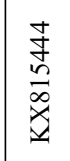 & \begin{tabular}{l}
$\hat{0}$ \\
\multirow{0}{0}{} \\
0
\end{tabular} & $\begin{array}{l}\hat{\tilde{o}} \\
\infty \\
\infty \\
\dot{\infty} \\
\tilde{n}^{\prime}\end{array}$ & & 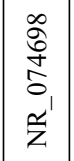 & 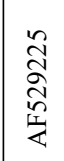 & $\begin{array}{l}\text { हे } \\
\text { ż}\end{array}$ & 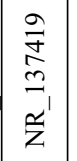 & 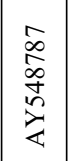 & & 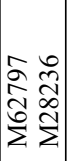 & 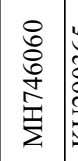 & 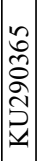 & 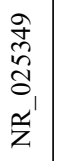 & 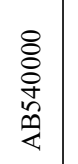 & 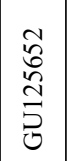 & 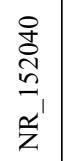 & 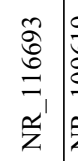 & $\left|\begin{array}{l}a \\
\overrightarrow{0} \\
0 \\
0 \\
\underline{z} \\
z\end{array}\right|$ & 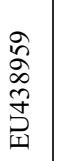 & 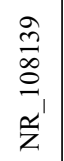 \\
\hline 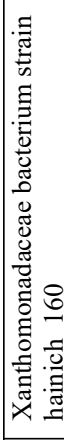 & 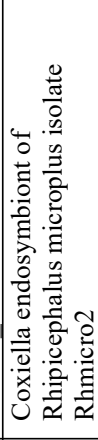 & 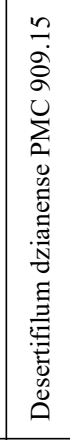 & 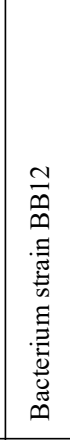 & 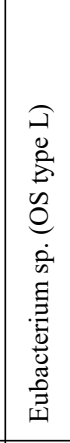 & 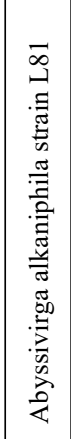 & 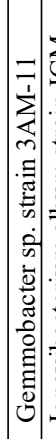 & 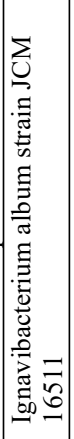 & 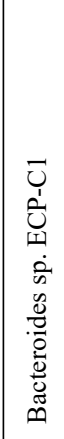 & 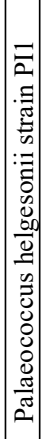 & 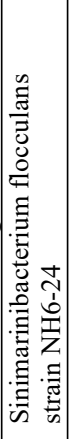 & 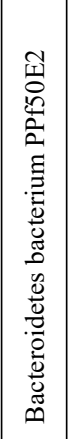 & 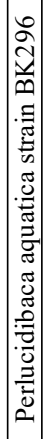 & 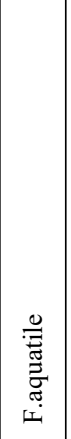 & 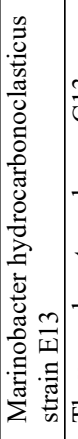 & 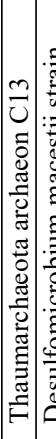 & & 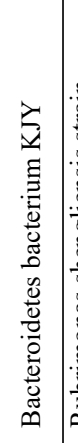 & 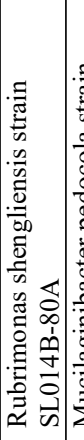 & 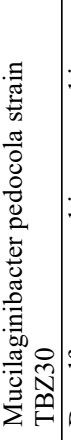 & 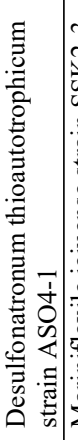 & 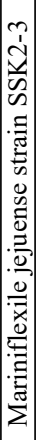 & 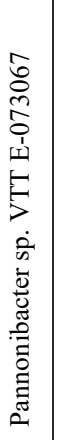 & 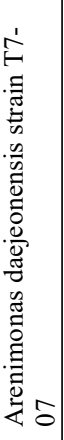 \\
\hline 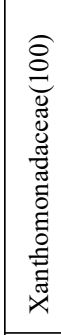 & 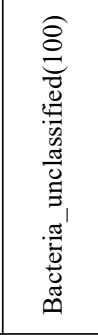 & 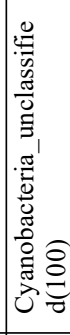 & 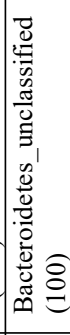 & 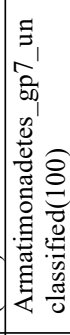 & 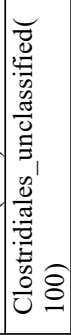 & 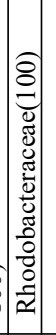 & 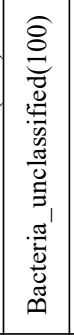 & 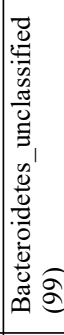 & 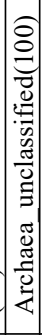 & 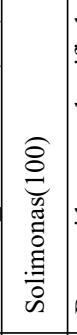 & 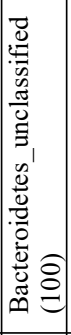 & 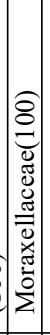 & 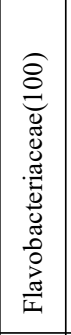 & 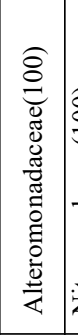 & 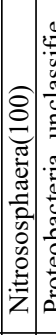 & & 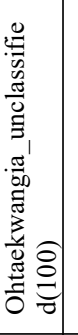 & 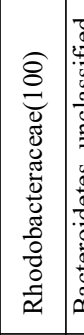 & 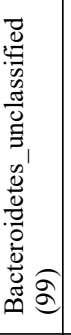 & 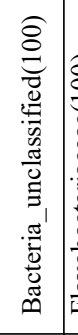 & 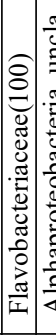 & 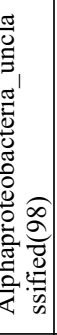 & 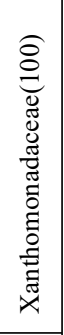 \\
\hline 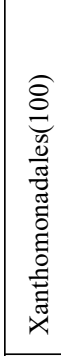 & 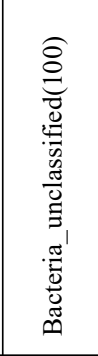 & 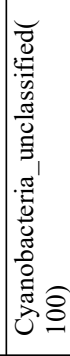 & 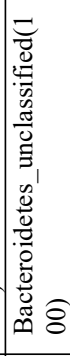 & 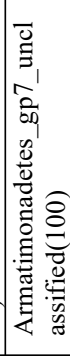 & 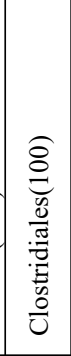 & 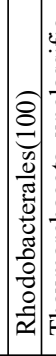 & 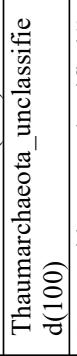 & 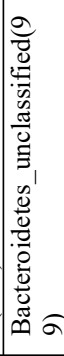 & 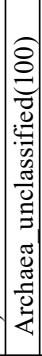 & 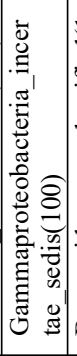 & 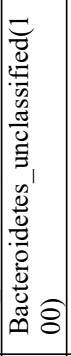 & 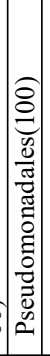 & 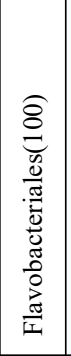 & 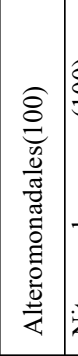 & 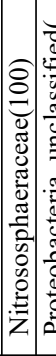 & & 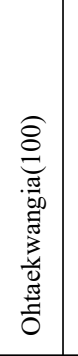 & 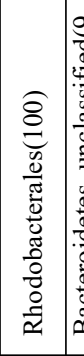 & 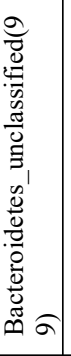 & 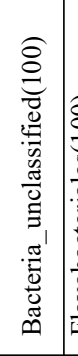 & $\mid$ & 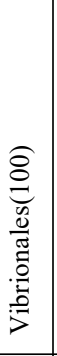 & 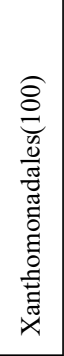 \\
\hline 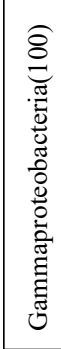 & 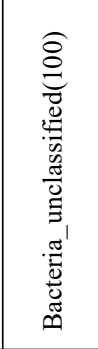 & 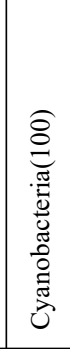 & 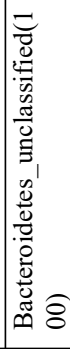 & 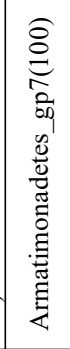 & 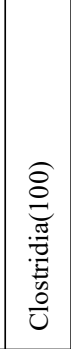 & 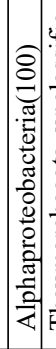 & 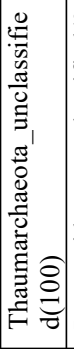 & 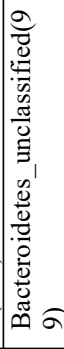 & 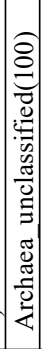 & 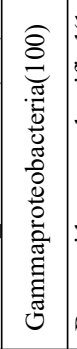 & 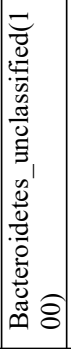 & 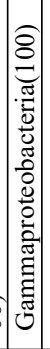 & 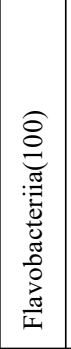 & 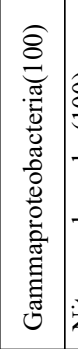 & 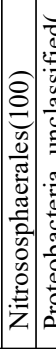 & & 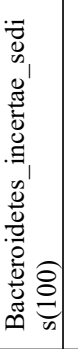 & 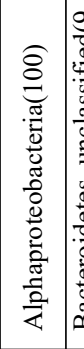 & 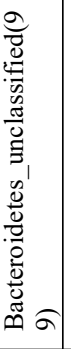 & 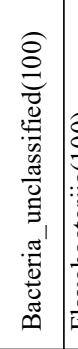 & 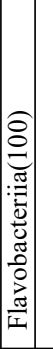 & 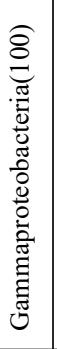 & 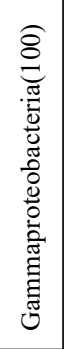 \\
\hline 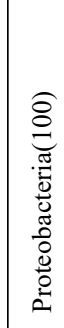 & 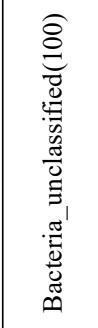 & 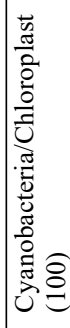 & 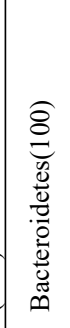 & 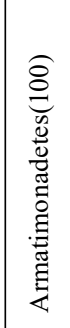 & 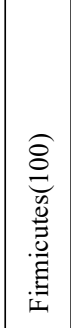 & 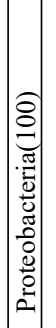 & 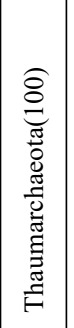 & 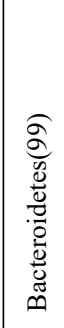 & 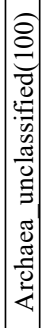 & 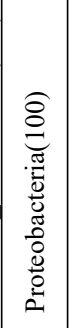 & 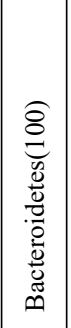 & 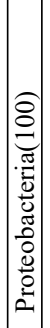 & 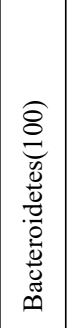 & 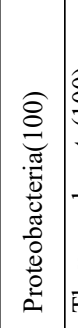 & 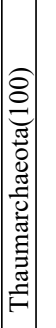 & & 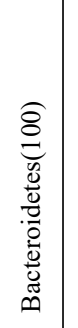 & 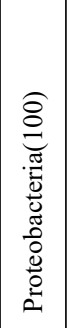 & 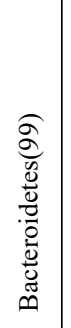 & 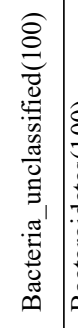 & 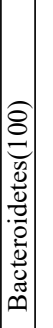 & 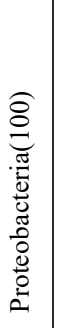 & 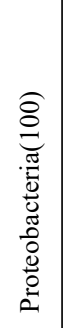 \\
\hline 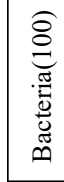 & 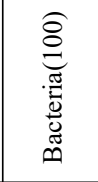 & 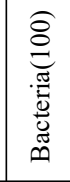 & 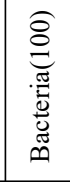 & 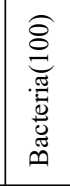 & 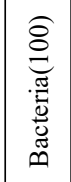 & 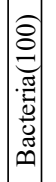 & 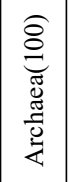 & 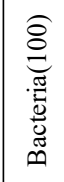 & 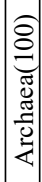 & 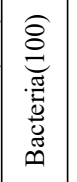 & 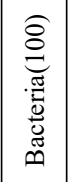 & 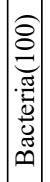 & 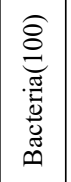 & 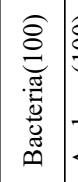 & 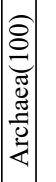 & & 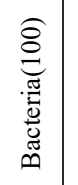 & 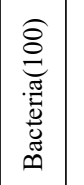 & 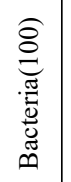 & 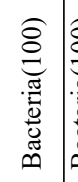 & 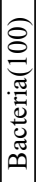 & 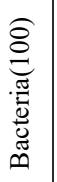 & 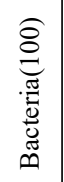 \\
\hline 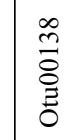 & 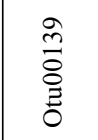 & 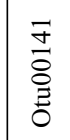 & 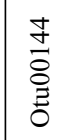 & 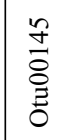 & 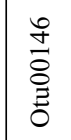 & $\left|\begin{array}{l}\hat{y} \\
\overline{0} \\
\vdots \\
\bar{z}\end{array}\right|$ & 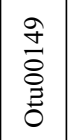 & $\begin{array}{l}\stackrel{0}{1} \\
\stackrel{0}{0} \\
\vdots \\
0\end{array}$ & $\vec{n}$ & $\begin{array}{l}\tilde{n} \\
\tilde{0} \\
\tilde{0} \\
\tilde{z}\end{array}$ & $\begin{array}{l}\tilde{n} \\
\stackrel{0}{0} \\
\vdots \\
0\end{array}$ & & 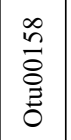 & $\begin{array}{l}\hat{n} \\
\overline{0} \\
\overline{0} \\
0\end{array}$ & $\left|\begin{array}{|}0 \\
0 \\
0 \\
0 \\
0 \\
0 \\
0\end{array}\right|$ & & $\begin{array}{l}\text { Oे } \\
\stackrel{0}{0} \\
\bar{\Xi}\end{array}$ & 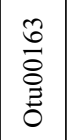 & 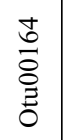 & $\mid \begin{array}{l}n \\
\vdots \\
0 \\
0 \\
0 \\
0\end{array}$ & $\left|\begin{array}{|}0 \\
0 \\
0 \\
0 \\
0 \\
0 \\
0\end{array}\right|$ & & 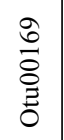 \\
\hline
\end{tabular}




\begin{tabular}{|c|c|c|c|c|c|c|c|c|c|c|c|c|c|c|c|c|c|c|c|c|c|c|c|c|c|}
\hline 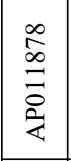 & 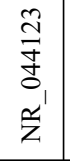 & 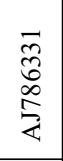 & 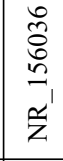 & 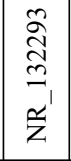 & $\begin{array}{l}\overrightarrow{\widetilde{N}} \\
\tilde{d} \\
\tilde{z}_{1}\end{array}$ & 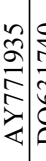 & 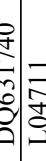 & $\begin{array}{l}0 \\
0 \\
0 \\
0 \\
0\end{array}$ & 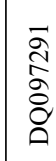 & 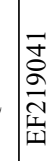 & 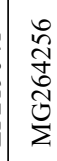 & & & 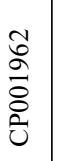 & $\begin{array}{l}\text { o } \\
0 \\
+ \\
0 \\
1 \\
\tilde{z}^{\prime}\end{array}$ & 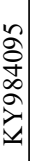 & 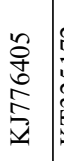 & ש & $\begin{array}{l}\ddot{a} \\
\hat{\sigma} \\
\vdots \\
\tilde{z}^{\prime} \\
\tilde{z}^{\prime}\end{array}$ & 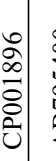 & & 帘 & $\begin{array}{l}\bar{\infty} \\
0 \\
o \\
0 \\
\tilde{n}^{\prime}\end{array}$ & 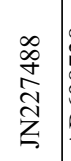 & \\
\hline 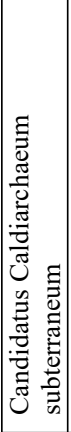 & 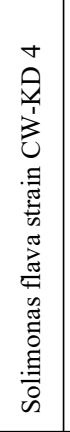 & 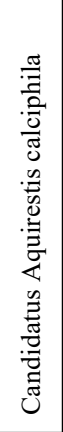 & 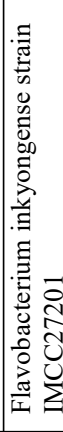 & 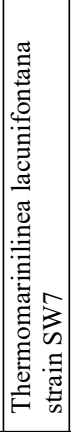 & 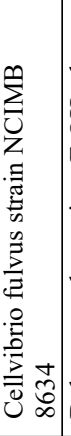 & ل & 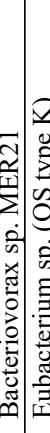 & 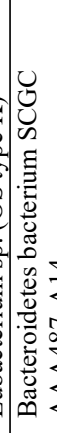 & 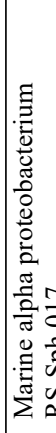 & 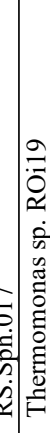 & 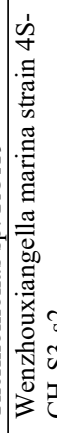 & 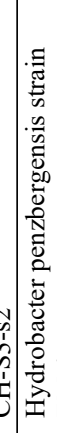 & & 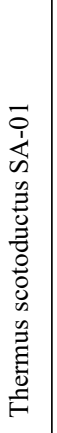 & 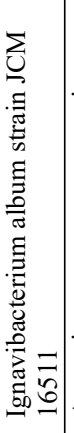 & & 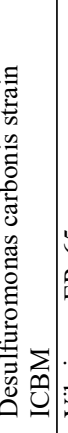 & & 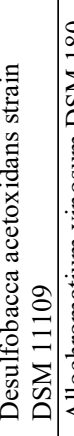 & 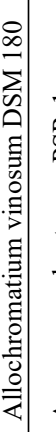 & 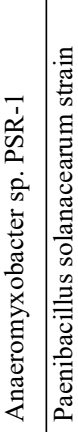 & 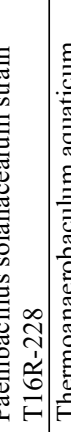 & 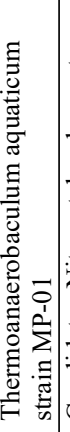 & 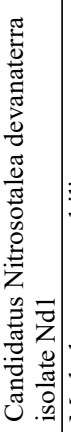 & \\
\hline 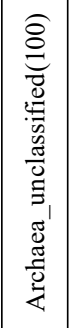 & 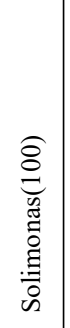 & 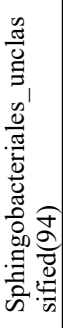 & 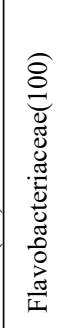 & 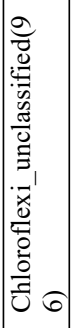 & 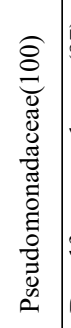 & 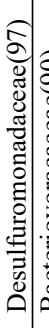 & & 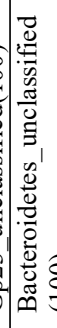 & 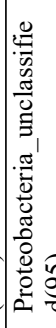 & 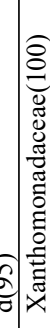 & 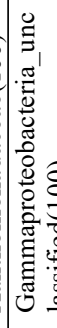 & 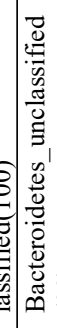 & & 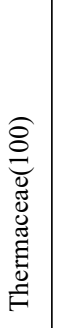 & 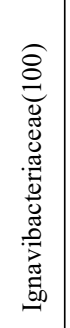 & & $\mathbb{E}$ & & 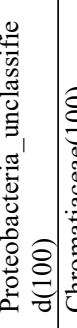 & 气̆ & 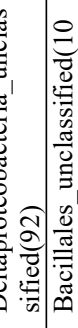 & 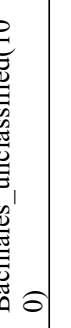 & 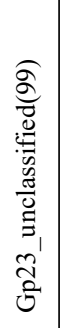 & 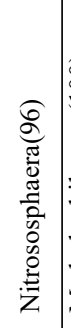 & \\
\hline 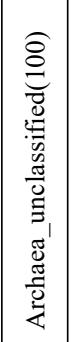 & 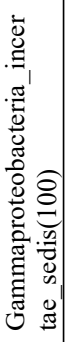 & 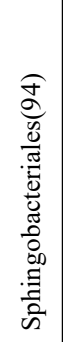 & 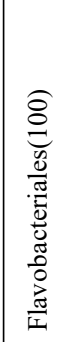 & 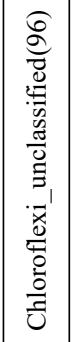 & 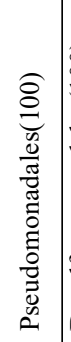 & 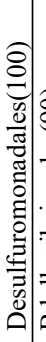 & & 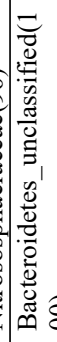 & 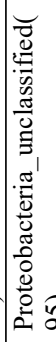 & 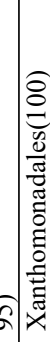 & 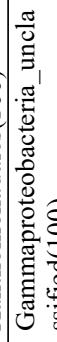 & 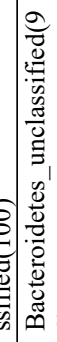 & & 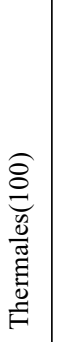 & 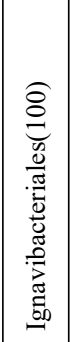 & 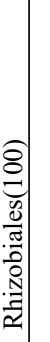 & 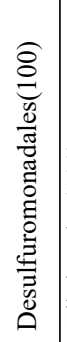 & & 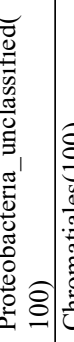 & 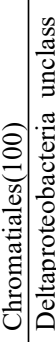 & & 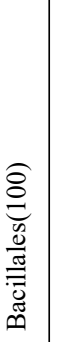 & $\begin{array}{l}\hat{\sigma} \\
\text { तె } \\
\hat{3}\end{array}$ & 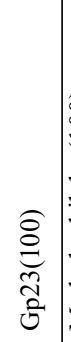 & \\
\hline 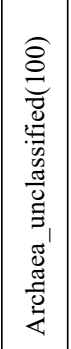 & 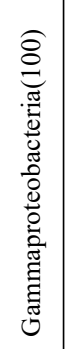 & 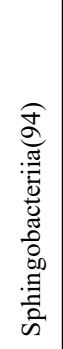 & 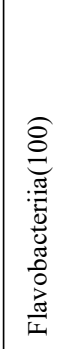 & 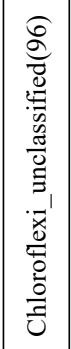 & 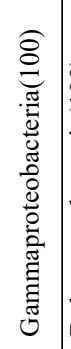 & 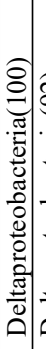 & & 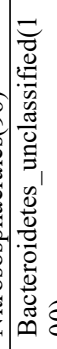 & 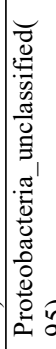 & 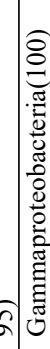 & 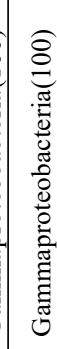 & 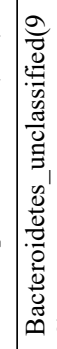 & & 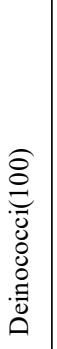 & 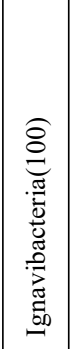 & & 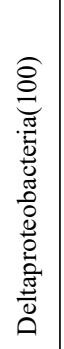 & & . & 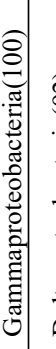 & 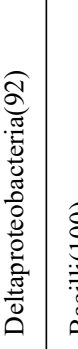 & 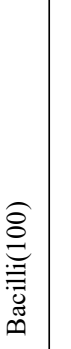 & 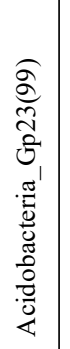 & 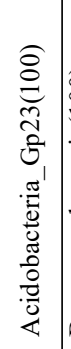 & \\
\hline
\end{tabular}

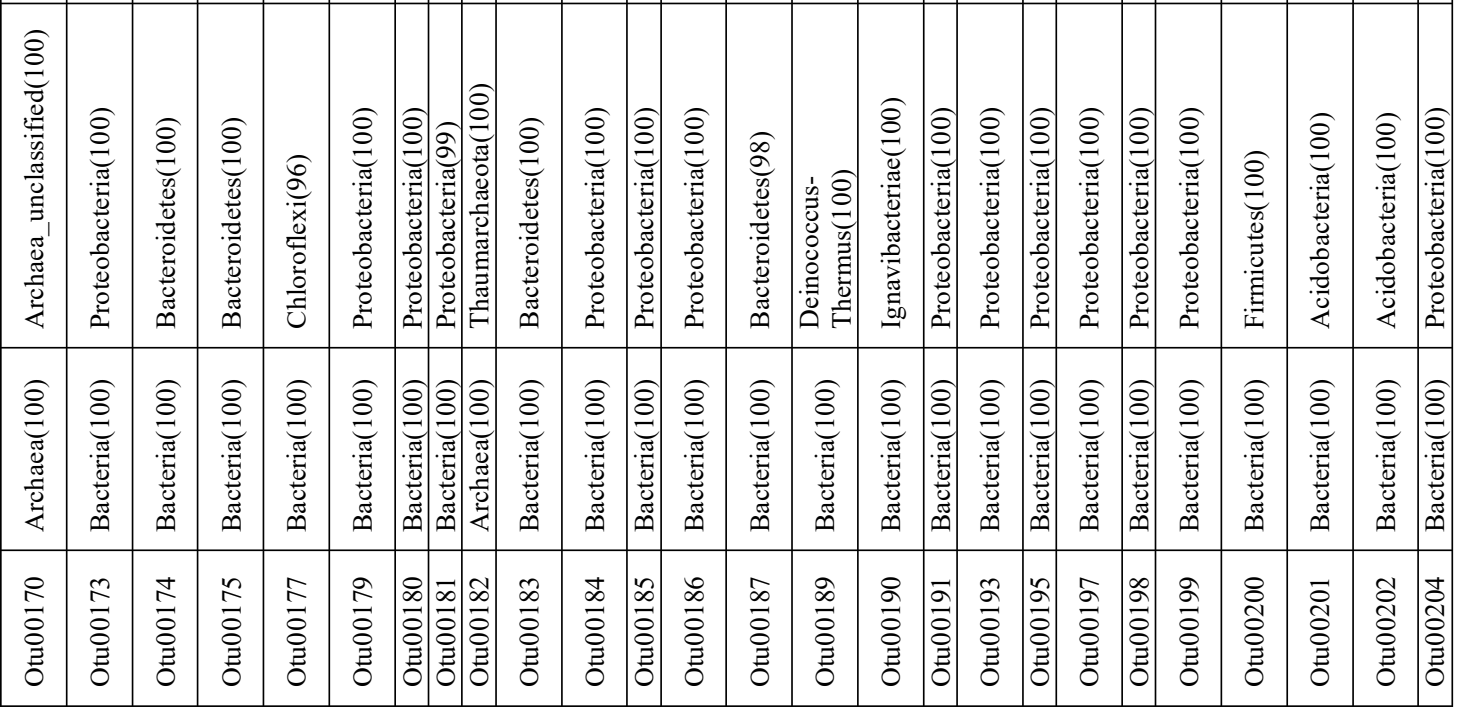




\begin{tabular}{|c|c|c|c|c|c|c|c|c|c|c|c|c|c|c|c|c|c|c|c|c|}
\hline$\frac{\text { }}{2}$ & 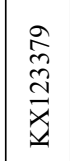 & $\begin{array}{l}\overrightarrow{\dot{D}} \\
\stackrel{2}{n} \\
\vec{z} \\
\underline{z}\end{array}$ & $\begin{array}{l}\overrightarrow{\vec{a}} \\
\stackrel{a}{\Xi} \\
\mathfrak{a}^{\prime} \\
z\end{array}$ & z & 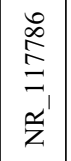 & 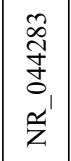 & 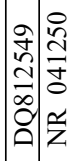 & 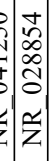 & 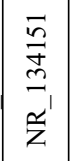 & 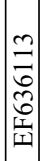 & 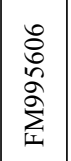 & & & $\frac{\tilde{J}}{\vec{d}}$ & & 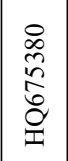 & & 绐 & 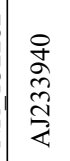 & 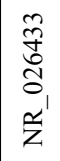 \\
\hline 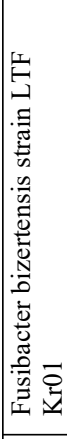 & 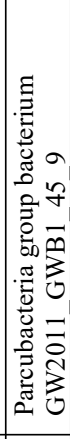 & 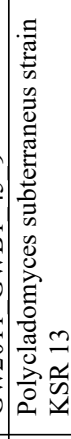 & 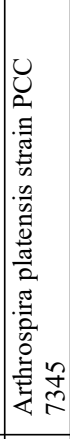 & 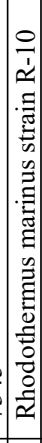 & 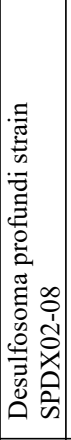 & 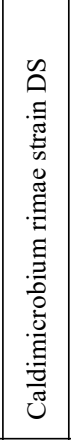 & 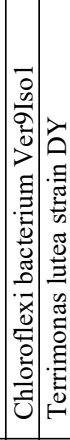 & 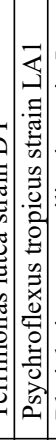 & 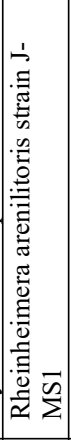 & 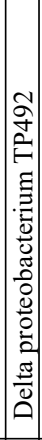 & 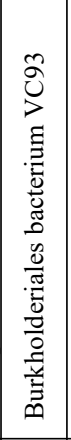 & 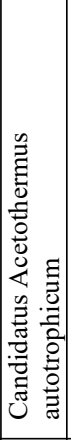 & 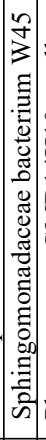 & 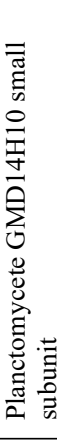 & & 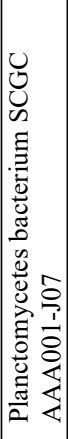 & & 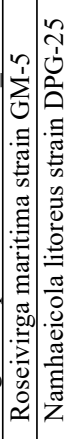 & 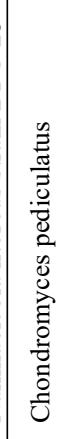 & 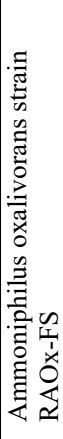 \\
\hline$\stackrel{8}{\varrho}$ & 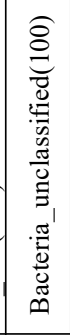 & 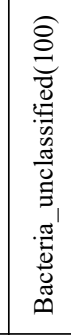 & 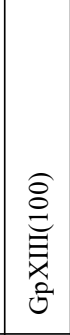 & 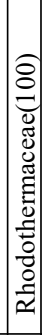 & 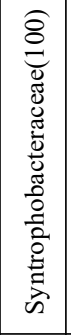 & 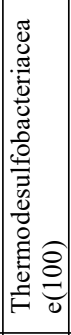 & 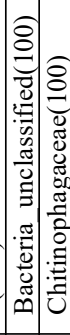 & 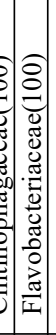 & 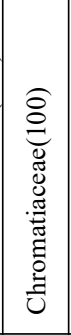 & 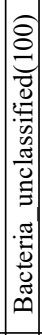 & 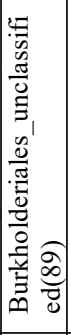 & 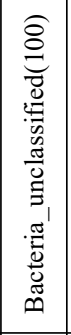 & 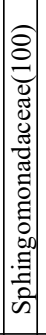 & 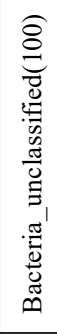 & 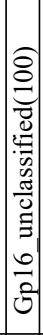 & 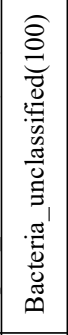 & & 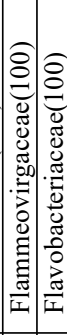 & 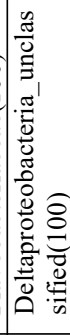 & 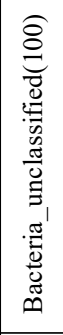 \\
\hline 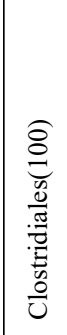 & 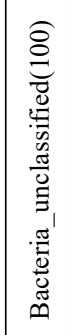 & 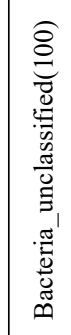 & 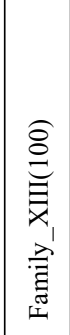 & 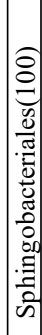 & 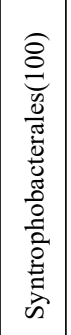 & 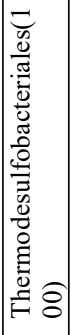 & 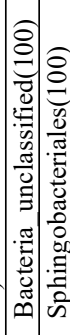 & 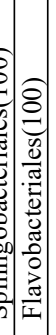 & 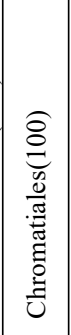 & 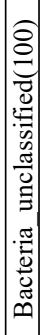 & 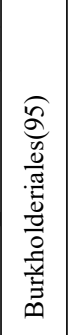 & 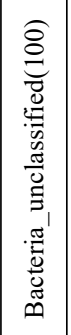 & 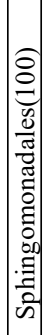 & 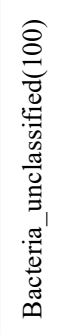 & 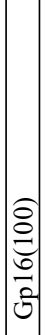 & 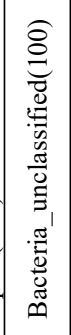 & & ఠ) & 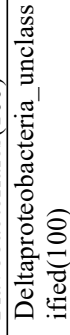 & 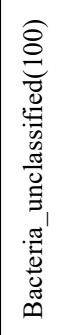 \\
\hline 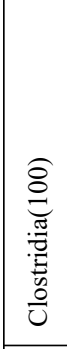 & 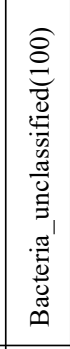 & 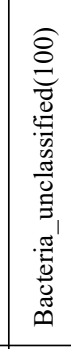 & 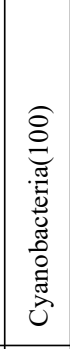 & 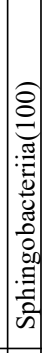 & 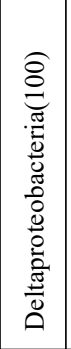 & 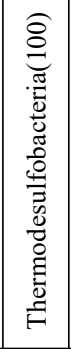 & 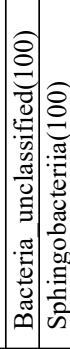 & 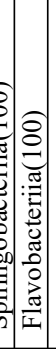 & 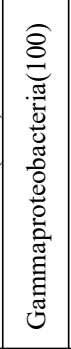 & 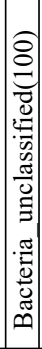 & 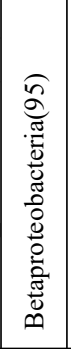 & 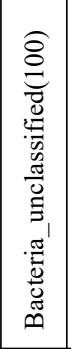 & 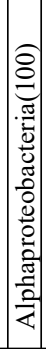 & 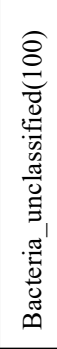 & 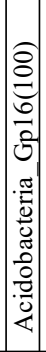 & 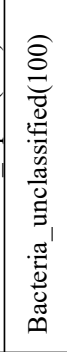 & & 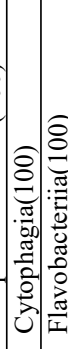 & $\begin{array}{ll}0 \\
0 \\
\delta\end{array}$ & 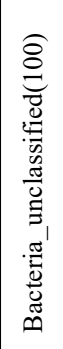 \\
\hline 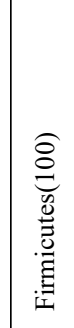 & 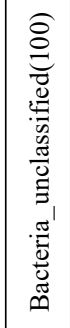 & 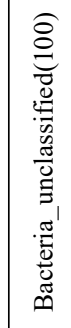 & 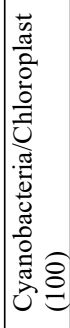 & 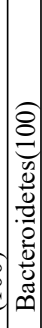 & 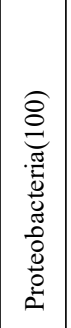 & 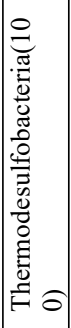 & 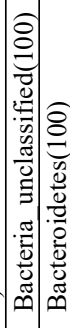 & 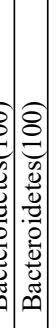 & 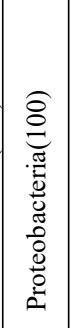 & 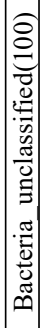 & 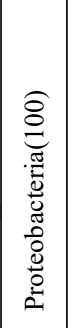 & 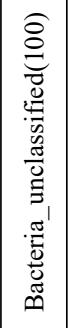 & 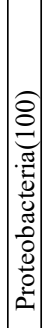 & 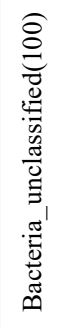 & 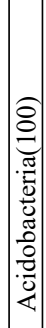 & 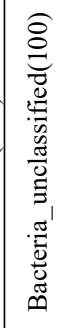 & & 5 & & 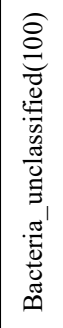 \\
\hline 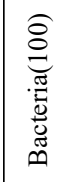 & 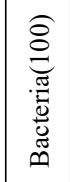 & 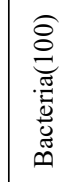 & 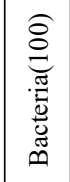 & 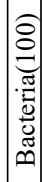 & 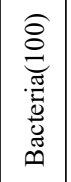 & 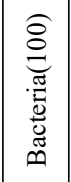 & & a. & 莺 & 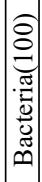 & 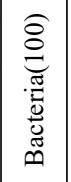 & 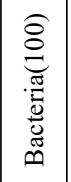 & $\frac{0}{2}$ & 丞 & 胥 & 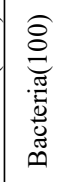 & & & & $\stackrel{G}{0}$ \\
\hline ڤิે & ఏั & 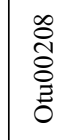 & 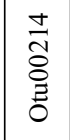 & & ఏ & 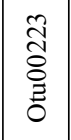 & 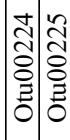 & 5 & & & 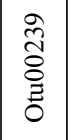 & 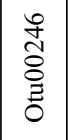 & & & & $\widetilde{\delta}$ & & & & \\
\hline
\end{tabular}


Appendix D. Additional microbiology donut charts 

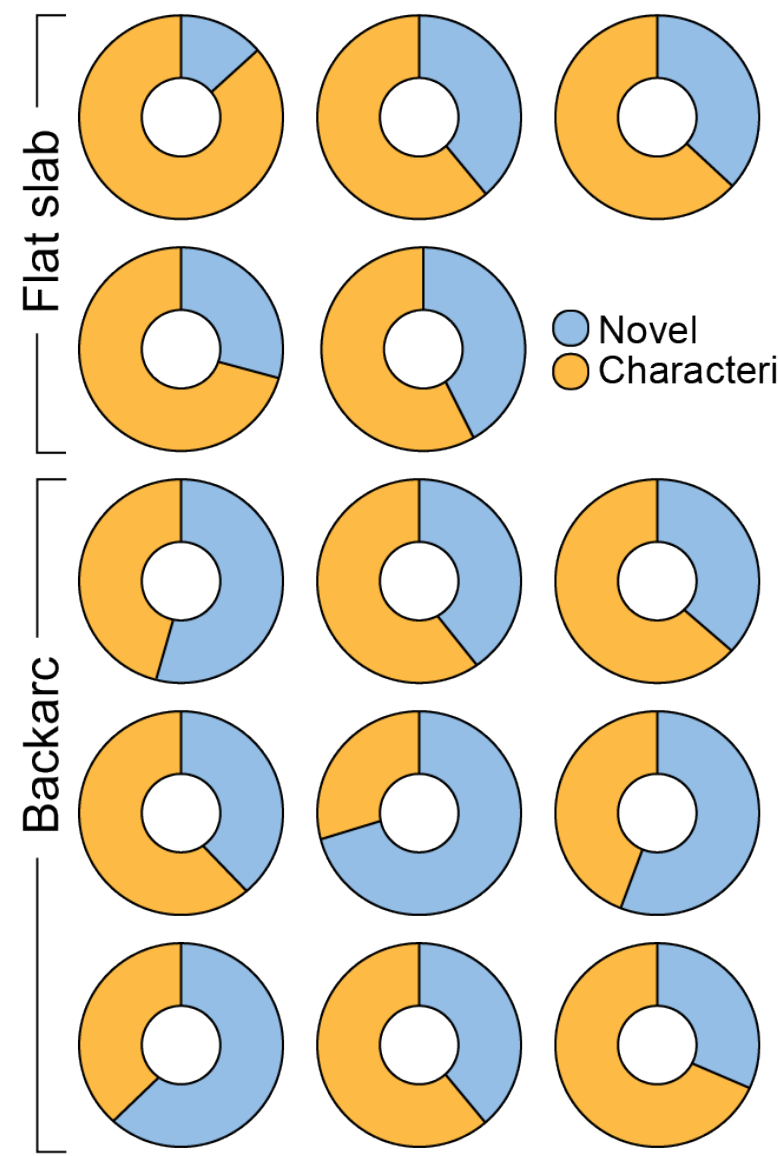

Figure A2. Donut charts for each spring show the amount of $\geq 1 \%$ abundance sequences that are previously characterized ( $\geq 97 \%$ ID match to known cultivars) or considered novel $(<97 \%$ ID match). The novel fraction is generally higher in BAS compared to those for FSS, indicating there are more uncharacterized microbes in springs in the back-arc setting. This is due, in part, to the geology of the backarc, fostering hot and magmatically influenced environments that sustain uncharacterized archaeal and bacterial assemblages. 


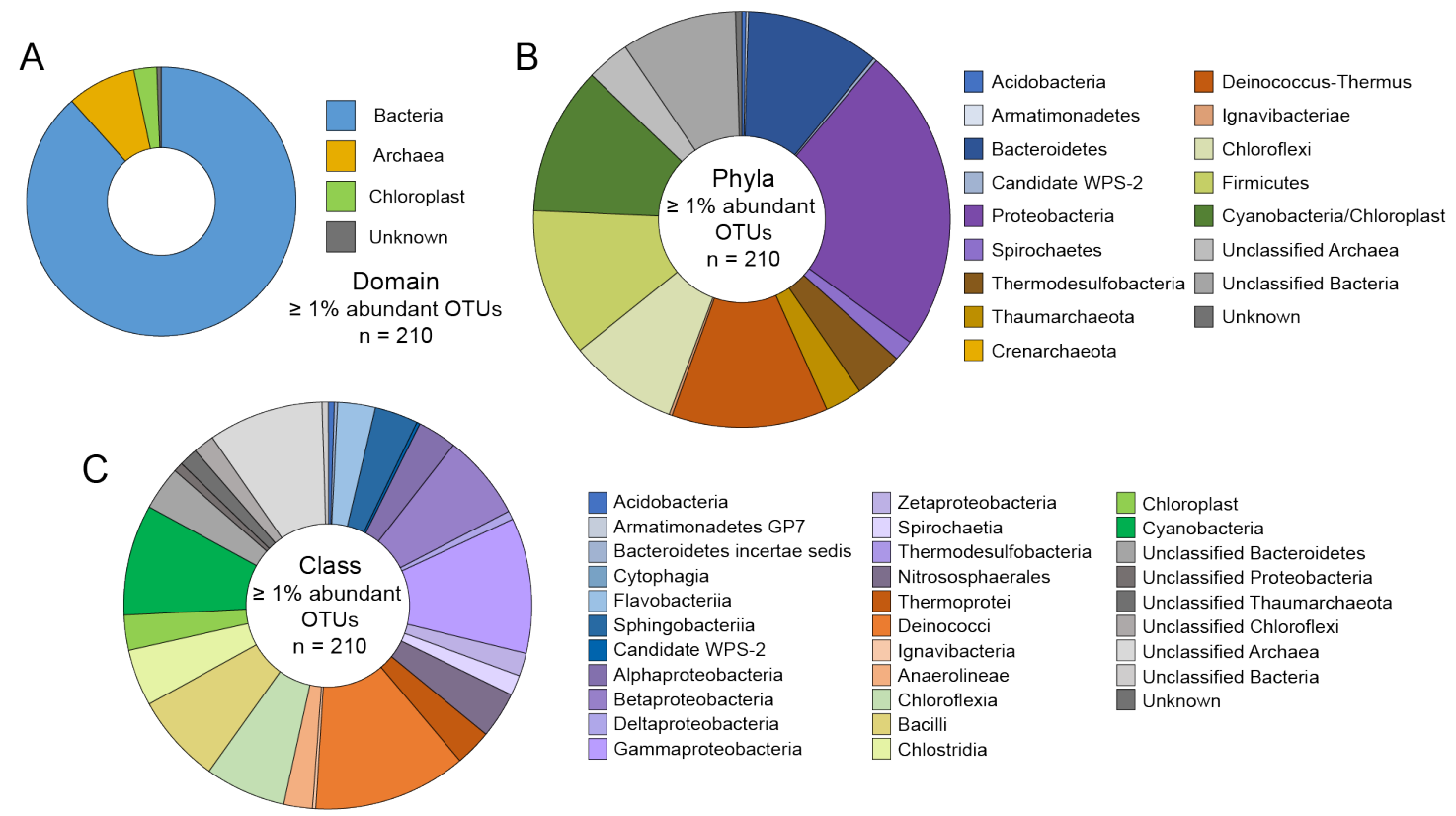

Figure A3. Donut charts at three levels of taxonomic classifications (A) Domain, (B) Phyla, (C) Class, for OTUs that are $\geq 1 \%$ abundance in at least one spring. The donuts are rudimentarily color-coded based on inferred metabolism or another key characteristic, where purple represents dominantly chemotrophs, orange signifies thermophiles, green shows dominantly phototrophs, blue represents general Bacteria, yellow represents Archaea, and grey signifies unknown or unclassified sequences. 
Appendix E. Additional NMDS ordinations and statistical summary 
A

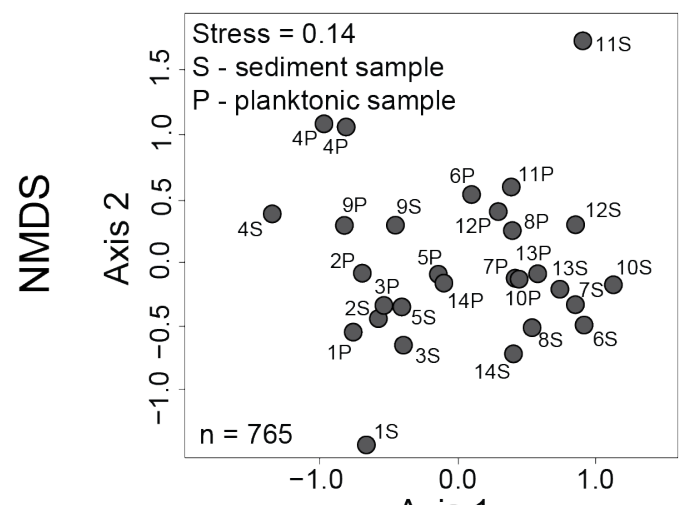

\section{Axis 1}
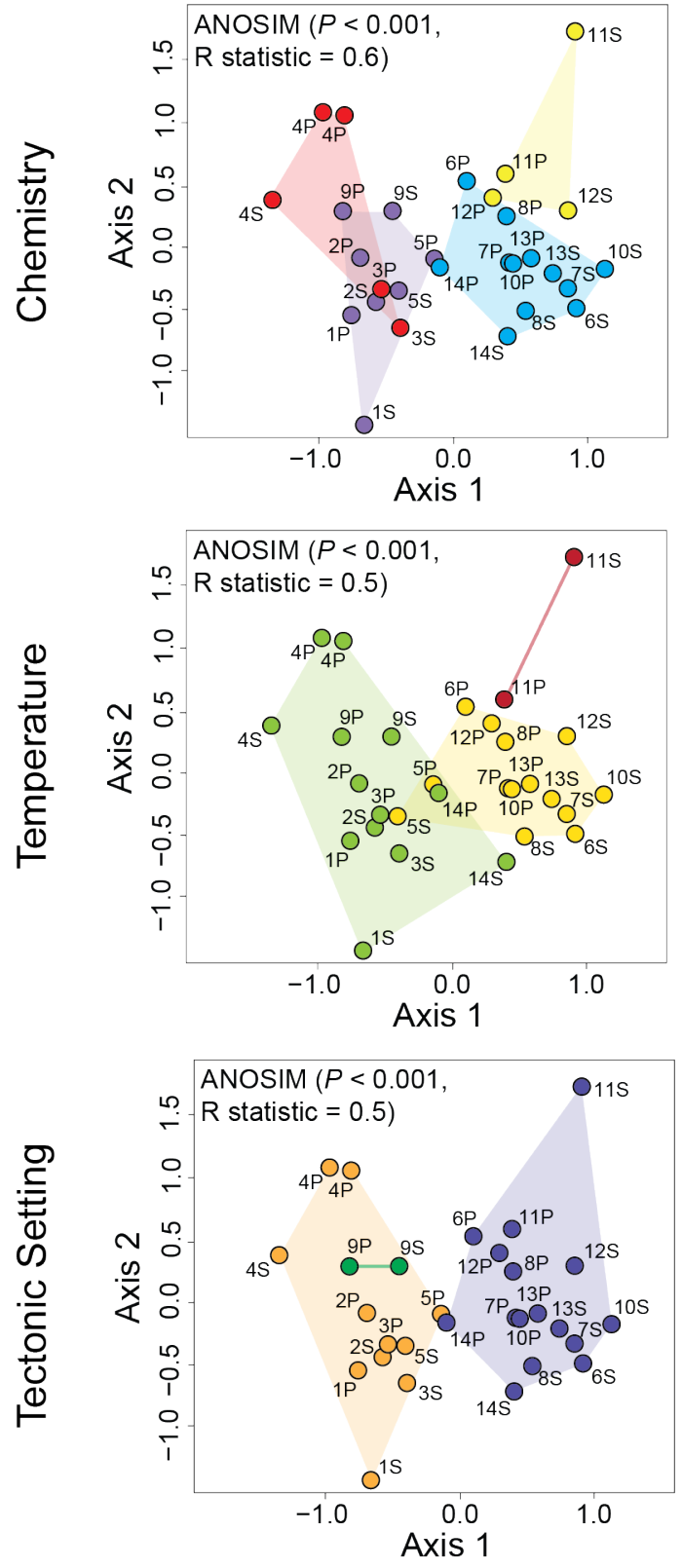

B

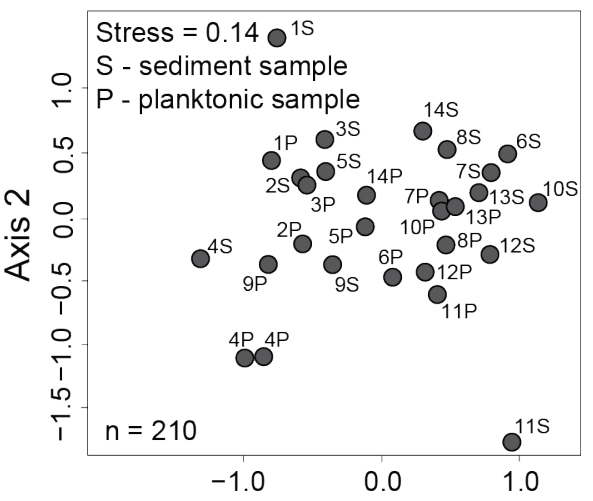

Axis 1

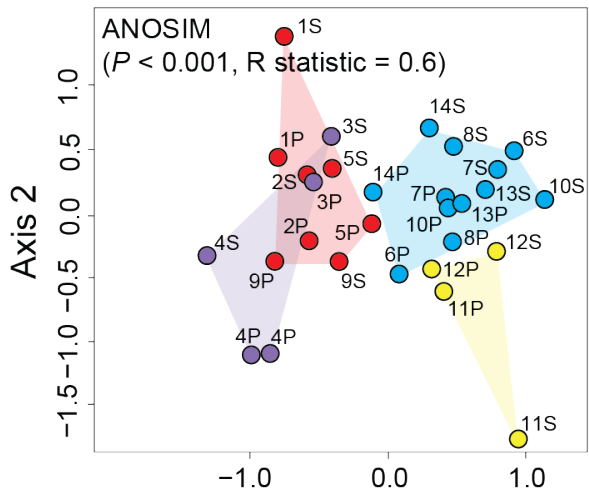

Axis 1
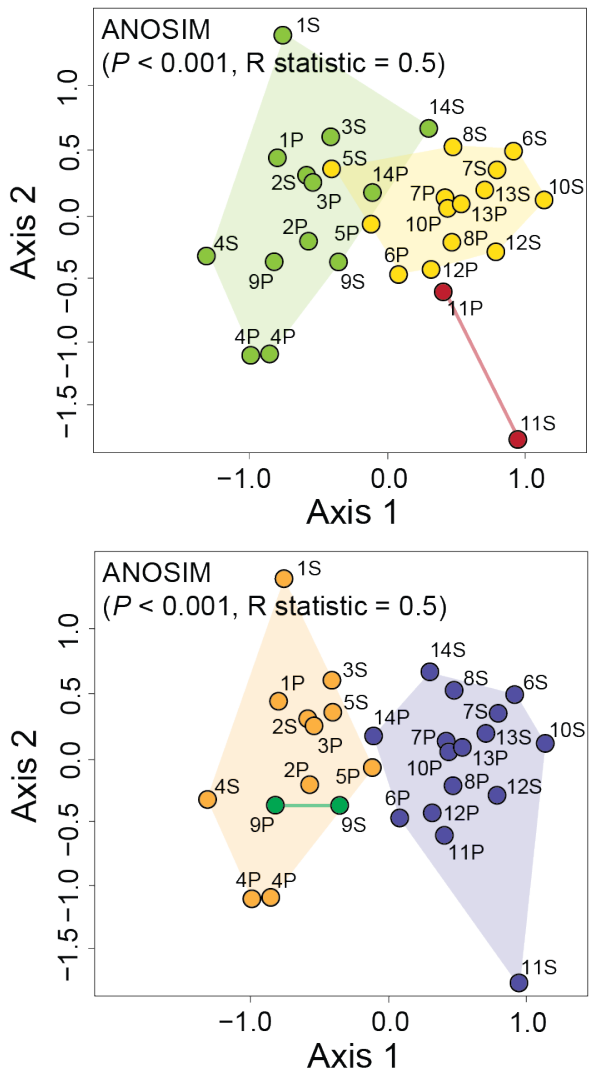

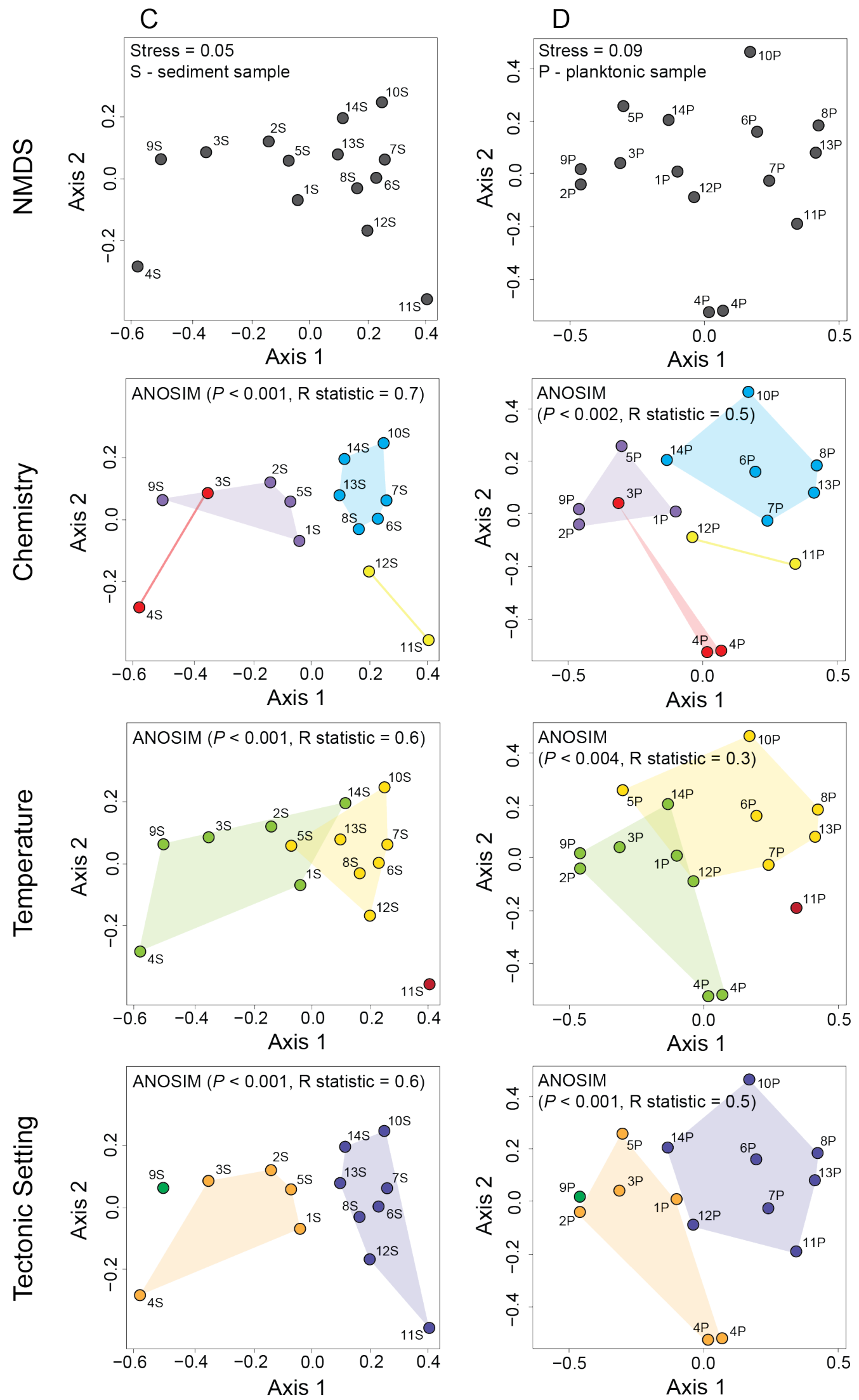

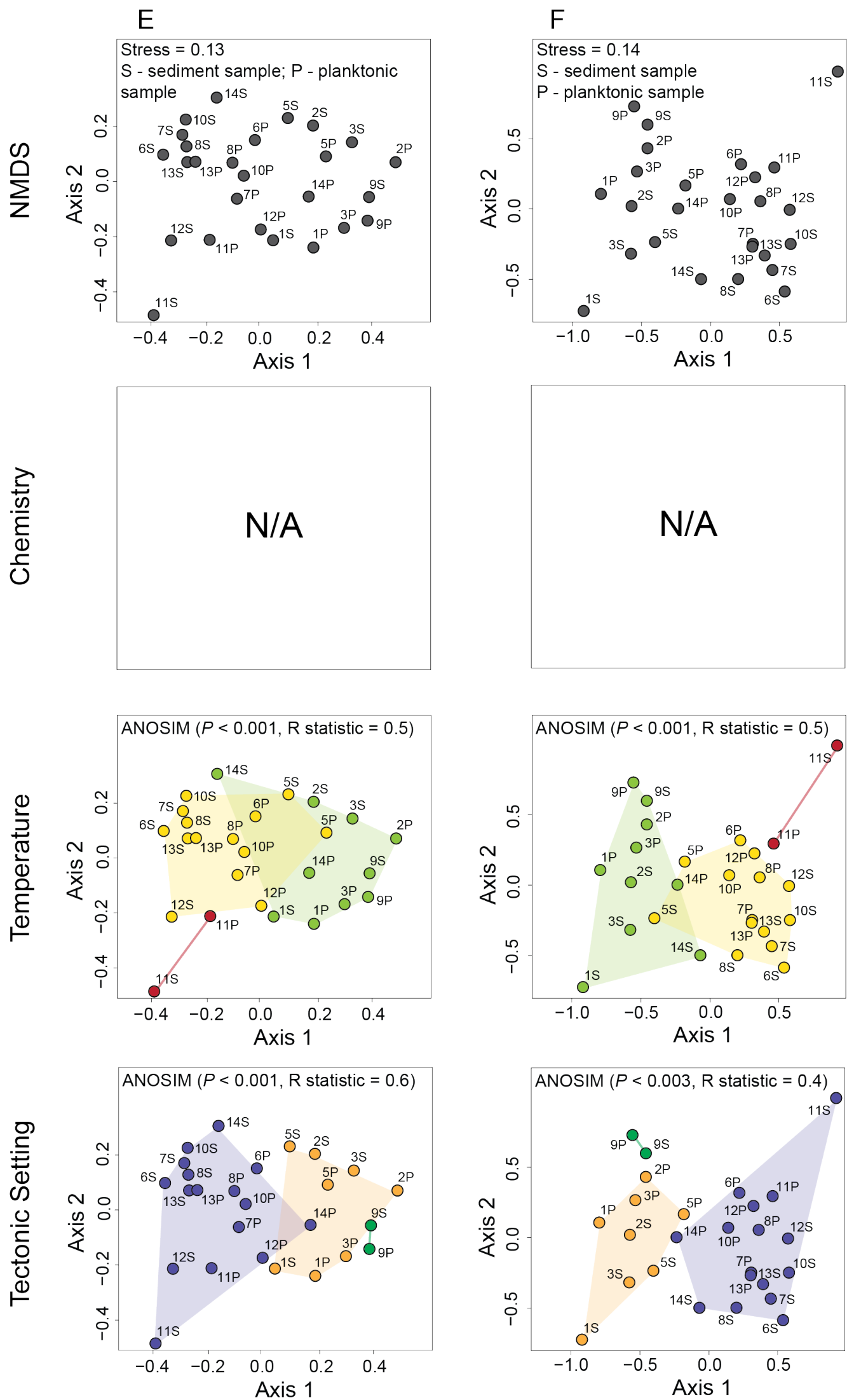
Figure A4. NMDS on subsampled datasets including: (A) OTUs $\geq 0.1 \%$ abundance, Sp. 1-14; (B) OTUs $\geq 1 \%$ abundance, Sp. 1-14; (C) Sediment OTUs, Sp. 1-14; (D) Planktonic OTUs, Sp. 1-14; (E) All OTUs, Sp. 1-14 excluding Sp. 4; (F) OTUs $\geq 1 \%$ abundance, Sp. 1-14 excluding Sp. 4. Eliminating OTUs based on abundance to reduce noise, for instance in $\mathrm{B}$ and $\mathrm{C}$, did not change the NMDS stress level. Likewise, for springs in the backarc (E and $\mathrm{F}$ ), the stress changed very little when subsampling for $\geq 1 \%$ abundance. The ANOSIM statistics are generally consistent across all subsampling. 
Table A4. Statistical summary for NMDS and ANOSIM. Classification: A - chemistry groups based on PCA; B - chemistry groups based on Piper diagram; C - temperature groups based on microbial temperature preference (i.e. mesophile); D - temperature groups based on $15{ }^{\circ} \mathrm{C}$ increments; E - tectonic setting groups (i.e. FSS and BAS) with Sp. 9 separate; F - tectonic setting groups FSS and BAS.

\begin{tabular}{|c|c|c|c|c|}
\hline \multirow{2}{*}{ Ordination } & \multirow{2}{*}{$\begin{array}{l}\text { NMDS } \\
\text { stress }\end{array}$} & \multicolumn{3}{|c|}{ ANOSIM } \\
\hline & & Classification & P value & R statistic \\
\hline \multirow{5}{*}{ All OTUs } & \multirow{5}{*}{0.14} & $\mathrm{~A}$ & 0.001 & 0.597 \\
\hline & & B & 0.343 & 0.039 \\
\hline & & $\mathrm{C}$ & 0.001 & 0.488 \\
\hline & & $\mathrm{D}$ & 0.001 & 0.386 \\
\hline & & E & 0.001 & 0.543 \\
\hline \multirow{3}{*}{$0.1 \%$ Abundant OTUs } & \multirow{3}{*}{0.14} & A & 0.001 & 0.584 \\
\hline & & $\mathrm{C}$ & 0.001 & 0.476 \\
\hline & & $\mathrm{E}$ & 0.001 & 0.533 \\
\hline \multirow{3}{*}{$1 \%$ Abundant OTUs } & \multirow{3}{*}{0.14} & A & 0.001 & 0.563 \\
\hline & & $\mathrm{C}$ & 0.001 & 0.468 \\
\hline & & $\mathrm{E}$ & 0.001 & 0.525 \\
\hline \multirow{6}{*}{ Planktonic Sample OTUs } & \multirow{6}{*}{0.09} & A & 0.002 & 0.510 \\
\hline & & B & 0.662 & -0.094 \\
\hline & & $\mathrm{C}$ & 0.004 & 0.329 \\
\hline & & $\mathrm{D}$ & 0.054 & 0.229 \\
\hline & & E & 0.001 & 0.519 \\
\hline & & $\mathrm{F}$ & 0.001 & 0.483 \\
\hline \multirow{6}{*}{ Sediment Sample OTUs } & \multirow{6}{*}{0.05} & A & 0.001 & 0.694 \\
\hline & & B & 0.493 & -0.017 \\
\hline & & $\mathrm{C}$ & 0.001 & 0.561 \\
\hline & & $\mathrm{D}$ & 0.003 & 0.402 \\
\hline & & $\mathrm{E}$ & 0.001 & 0.544 \\
\hline & & $\mathrm{F}$ & 0.003 & 0.534 \\
\hline \multirow{3}{*}{ All OTUs excluding Spring 4} & \multirow{3}{*}{0.13} & A & 0.001 & 0.268 \\
\hline & & $\mathrm{C}$ & 0.001 & 0.538 \\
\hline & & $\mathrm{E}$ & 0.001 & 0.574 \\
\hline \multirow{4}{*}{$\begin{array}{c}\text { 1\% Abundant OTUs excluding } \\
\text { Spring } 4\end{array}$} & \multirow{4}{*}{0.14} & A & 0.005 & 0.237 \\
\hline & & $\mathrm{C}$ & 0.001 & 0.516 \\
\hline & & $\mathrm{E}$ & 0.003 & 0.388 \\
\hline & & $\mathrm{F}$ & 0.001 & 0.553 \\
\hline $\begin{array}{l}\text { 1\% Abundant OTUs for } \\
\text { Springs } 1-5\end{array}$ & 0.04 & - & - & - \\
\hline $\begin{array}{l}\text { 1\% Abundant OTUs for } \\
\text { Springs } 1-3,5\end{array}$ & 0.02 & - & - & - \\
\hline All OTUs for Springs 6-14 & 0.11 & $\mathrm{C}$ & 0.004 & 0.532 \\
\hline $\begin{array}{c}\text { 1\% Abundant OTUs for } \\
\text { Springs 6-14 }\end{array}$ & 0.12 & $\mathrm{C}$ & 0.001 & 0.533 \\
\hline
\end{tabular}


Appendix D. R code 


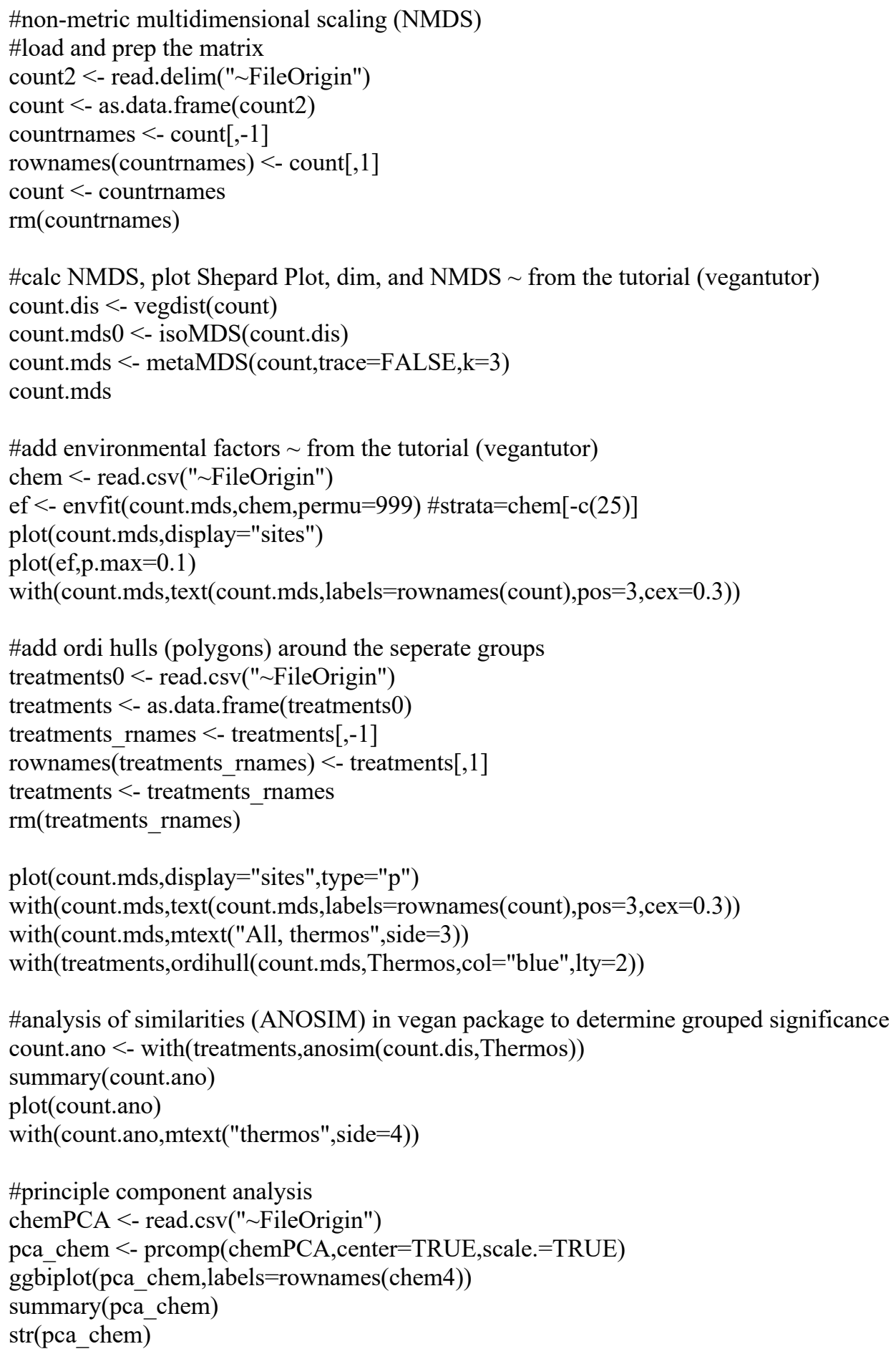

